\title{
United Kingdom: Financial System Stability Assessment
}

This paper was prepared based on the information available at the time it was completed on July 11, 2011. The views expressed in this document are those of the staff team and do not necessarily reflect the views of the government of the United Kingdom or the Executive Board of the IMF.

The policy of publication of staff reports and other documents by the IMF allows for the deletion of market-sensitive information.

Copies of this report are available to the public from

International Monetary Fund $\bullet$ Publication Services

700 19th Street, N.W. • Washington, D.C. 20431

Telephone: (202) 623-7430 • Telefax: (202) 623-7201

E-mail: publications@imf.org • Internet: http://www.imf.org

\section{International Monetary Fund Washington, D.C.}




\title{
INTERNATIONAL MONETARY FUND
}

\section{UNITED KINGDOM}

\section{Financial System Stability Assessment Update}

\author{
Prepared by the Monetary and Capital Markets and European Departments
}

\author{
Approved by José Viñals and Antonio Borges
}

July 11, 2011

\begin{abstract}
This report summarizes the findings of the Financial Sector Assessment Program (FSAP) Update for the United Kingdom (U.K.). The assessment involved two missions, January 12-February 1 and March 24-April 5, 2011. The team comprised Robert Sheehy and Ceyla Pazarbasioglu (co-heads), Li Lian Ong (deputy), Jennifer Elliott, Andreas Jobst, Vanessa Le Leslé, Christine Sampic, and Rodolfo Wehrhahn (all IMF/MCM); Sean Kerr (IMF/LEG); Marta Ruiz Arranz (IMF/EUR); and the following IMF external consultants: Nikil Chande, Nick Le Pan, Tom Karp, Göran Lind, Antonio Pancorbo, Pierre-Yves Thoraval, and Shane Tregillis.

Decisive policy responses during the crisis have stabilized the financial system, but vulnerabilities remain and recovery is not yet assured. The size and role of the U.K. financial system in global intermediation means that its continuing stability is a global public good necessitating effective implementation of reforms:
\end{abstract}

U.K. banks have made progress in repairing balance sheets following the crisis, but the recovery process is not yet complete. The restructuring of the two large banks with government stakes is ongoing and rigorous followthrough will be essential. Stress tests suggest adequate levels of capitalization under severe macroeconomic scenarios - with the caveat that lender forbearance may, in some cases, have masked the extent of risks, given the high indebtedness of the household and commercial real estate sectors. Risks from exposures to vulnerable European sovereigns seem manageable but potential major spillovers to the private sector in those countries and to core European banks could lead to liquidity and solvency concerns. The new discount window facility and prepositioning of collateral to facilitate access to the facility are important in managing such extreme stresses.

The supervisory approach has been strengthened but more needs to be done to embed and enhance the new processes. Regulatory requirements have been strengthened and need to be complemented with high-quality supervision. A key concern is that the transition to the new "triple peak" model of regulation (microprudential, financial conduct, and macroprudential) may divert resources and attention from efforts to enhance supervision of the financial sector, which is still in recovery mode.

The stability of the U.K. financial sector critically depends on a stronger international framework for oversight of cross-border financial institutions and market infrastructures. There are limitations to what the United Kingdom can do alone, particularly with respect to institutions that it hosts, such as branches of foreign bank entities. Gaps in this domain must be addressed through international cooperation. The authorities should continue to push for an ambitious international package of regulatory reforms.

FSAP assessments are designed to assess the stability of the financial system as a whole and not that of individual institutions. They have been developed to help countries identify and remedy weaknesses in their financial sector structure, thereby enhancing their resilience to macroeconomic shocks and cross-border contagion. FSAP assessments do not cover risks that are specific to individual institutions such as asset quality, operational or legal risks, or fraud. 
Contents Page

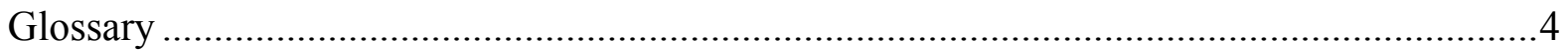

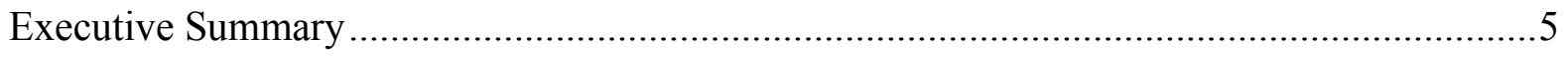

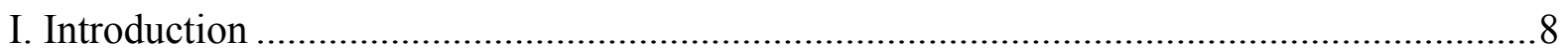

II. Soundness of the Financial System and Potential Risks ......................................................11

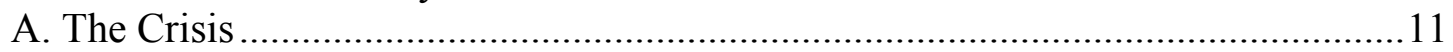

B. Financial Sector Conditions in the Aftermath of the Crisis ....................................14

C. Macroeconomic and Financial Risks .....................................................................16

III. Toward a More Effective Oversight Framework.................................................................37

A. Dealing with Too-Important-to-Fail and the International Dimension.....................38

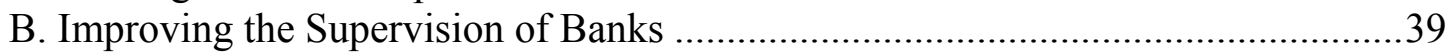

C. Strengthening Insurance Supervision..................................................................

D. Effective Regulation of Securities Markets ............................................................42

E. Strengthening the Regulation of Financial Market Infrastructures ..........................43

F. Crisis Management and Resolution.................................................................4

G. Anti-Money Laundering and Combating the Financing of Terrorism Framework 46

Tables

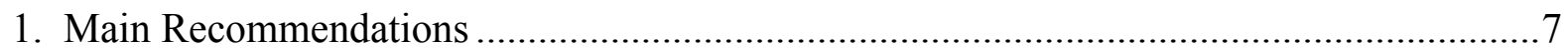

2. Global Market Share in Financial Services ................................................................

3. Composition of the Banking System .............................................................................. 13

4. Selected Advanced Economies: Recovery of Outlays and Net Cost of Financial Sector

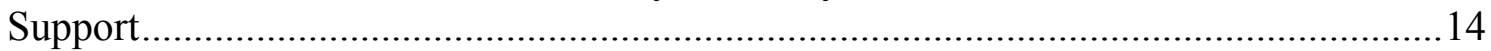

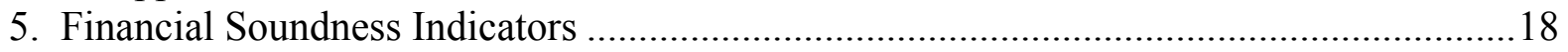

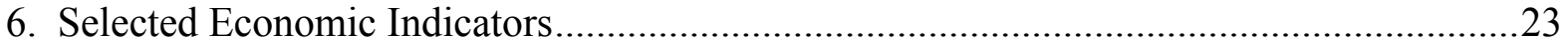

7. Systemic CCA Estimates of the Market-Implied Joint Expected Capital Loss and Resulting Shortfall from the U.K. FSAP Update Top-Down Stress Tests, 2011-15 ......33

8. U.K. FSAP Update Liquidity Stress Tests-5- and 30-Day Implied Cash Flow

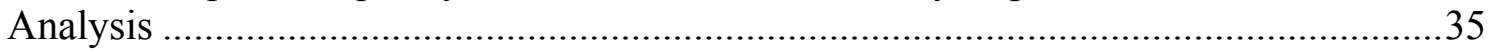

9. U.K. FSAP Update Liquidity Stress Tests-Quasi-Basel III and Maturity Mismatch

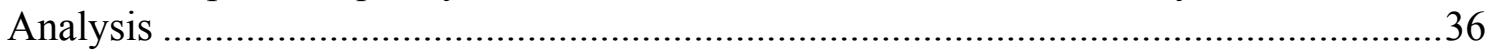

Figures

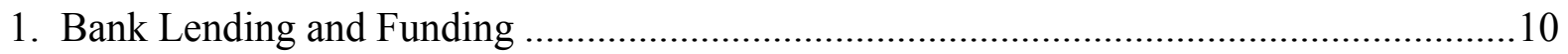

2. U.K. Banks: Differentiated Geographic and Business Models .........................................12

3. U.K. Banking System: Composition of Assets and Risk-Weighted Assets .......................19

4. Funding Issuance by Banks and Their Maturity Profiles ..................................................2

5. Financial Soundness of Major Banks ……………....................................................2

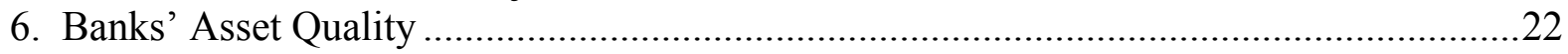

7. Overview of the U.K. FSAP Update Stress Testing Exercise ...........................................28

8. Overview of the U.K. FSAP Update Stress Test Scenarios ...............................................29 
9. Distribution of Core Tier 1 Capital Ratios from the U.K. FSAP Update Bottom-Up Stress

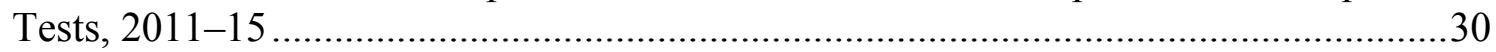

10. Weighted-Average Core Tier 1 Capital Ratios from the U.K. FSAP Update Bottom-Up and BoE RAMSI Top-Down Stress Tests, 2011-15 …………………………….........

11. Systemic CCA Estimates of the Market-Implied Joint Capital Losses from the U.K. FSAP Update Top-Down Stress Tests, Historical and Expected.............................32

12. Selected EU Countries: CDS Spreads ……………......................................................

Boxes

1. Did Trading Activities Increase the Vulnerability of Banks to Financial Stress? …….......47

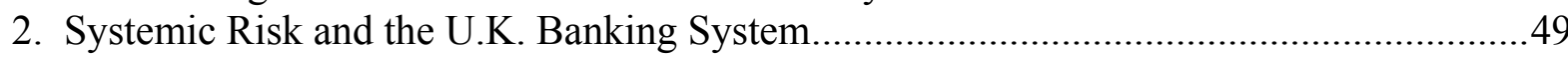

3. Vulnerabilities of U.K. Household and Corporate Balance Sheets and Risks to the Financial Sector

Appendices

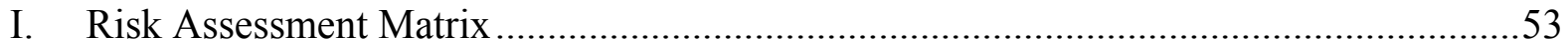

II. Key Policy Measures Taken During the Crisis .............................................................55

III. Estimation of Satellite Models in the U.K. FSAP Update Stress Testing Exercise

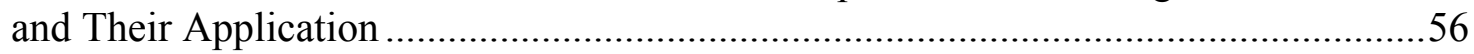

IV. Key Assumptions Applied in the U.K. FSAP Update Solvency Stress Tests....................57

V. Parameters Applied in the U.K. FSAP Update Liquidity Stress Tests...............................62

VI. Hedge Funds, Prime Brokerage and Collateral Rehypothecation in the United Kingdom 


\section{GLOSSARY}

$\begin{array}{ll}\text { AML/CFT } & \text { Anti-Money Laundering/Combating the Financing of Terrorism } \\ \text { APF } & \text { Asset Purchase Facility } \\ \text { APS } & \text { Asset Protection Scheme } \\ \text { BACS } & \text { Bankers' Automated Clearing Services } \\ \text { BoE } & \text { Bank of England } \\ \text { CCP } & \text { Central counterparty } \\ \text { CDS } & \text { Credit default swap } \\ \text { CGS } & \text { Credit Guarantee Scheme } \\ \text { CHAPS } & \text { Clearing House Automated Payment System } \\ \text { CPP } & \text { Core Prudential Program } \\ \text { CPPi } & \text { Core Prudential Program Insurance } \\ \text { CRE } & \text { Commercial real estate } \\ \text { EU } & \text { European Union } \\ \text { FCA } & \text { Financial Conduct Authority } \\ \text { FPC } & \text { Financial Policy Committee } \\ \text { FSA } & \text { Financial Services Authority } \\ \text { HMT } & \text { Her Majesty's Treasury } \\ \text { FPS } & \text { Faster Payments Service } \\ \text { FSCS } & \text { Financial Services Compensation Scheme } \\ \text { HSBC } & \text { Hong Kong and Shanghai Banking Corporation } \\ \text { ICB } & \text { Independent Commission on Banking } \\ \text { LBG } & \text { Lloyds Banking Group } \\ \text { LTV } & \text { Loan-to-value } \\ \text { PRA } & \text { Prudential Regulation Authority } \\ \text { RAMSI } & \text { Risk Assessment Model for Systemic Institutions } \\ \text { RBS } & \text { Royal Bank of Scotland } \\ \text { RTGS } & \text { Real time gross settlement } \\ \text { SCB } & \text { Standard Chartered Bank } \\ \text { SEP } & \text { Supervisory Enhancement Program } \\ \text { SLS } & \text { Special Liquidity Scheme } \\ \text { SRR } & \text { Special Resolution Regime } \\ \text { TITF } & \text { Too-important-to-fail } \\ & \end{array}$




\section{EXECUTIVE SUMMARY}

The past four years have witnessed a crisis of unprecedented proportion in the U.K. financial sector and its regulatory framework. Significant risks posed by large, complex, and interconnected financial institutions crystallized, exposing weaknesses in the policy and regulatory framework that had enabled their expansion and complexity, both domestically and internationally. This report is written at a time when the key decisions on the role of the financial sector and the regulatory framework are still being formulated.

Given the gaps in the crisis management framework, the authorities initially resorted to ad hoc solutions, but thereafter rapidly introduced a new framework. The lack of crisis management mechanisms meant disruptive and expensive outcomes in the early stages of the crisis. However, decisive actions were taken and an improved framework, including an enhanced deposit insurance scheme and a new Special Resolution Regime, was implemented to resolve or restructure failing institutions.

\section{U.K. banks have made progress in repairing their balance sheets, but the recovery} process is not yet complete (see Risk Assessment Matrix, Appendix I). The two large banks with government stakes are implementing their restructuring plans, but important challenges remain. Stress tests suggest adequate levels of capitalization under severe macroeconomic scenarios - with the caveat that lender forbearance may, in some cases, have masked the extent of risks, given the high indebtedness of the household and commercial real estate sectors. Risks from exposures to vulnerable European sovereigns seem manageable, but potential major spillovers to the private sector in those countries and to core European banks could lead to solvency concerns. Also, although liquidity positions have improved, U.K. banks are vulnerable to sustained disruptions in funding markets. The new discount window facility and prepositioning of collateral aimed at facilitating quick use of the facility are important in managing such extreme stress events.

\section{Requiring financial institutions to build up capital and liquidity buffers is thus proper} and necessary. The aggregate balance sheet of the banking sector, at about five times GDP, still remains sizeable. The Financial Services Authority (FSA) has imposed stringent capital and liquidity regulations that require resilience under stressed conditions and approval of dividends and variable remuneration is linked to the outcome of stress tests. These safeguards are appropriate, given the specific vulnerabilities of the U.K. financial system, and should be accompanied by home-host coordination to address liquidity needs in times of stress. In particular, U.K. supervisors need to monitor closely the liquidity position of large foreign branches, which have systemic relevance for the U.K. financial system.

Supervisory approach for banks and insurers need to be further strengthened. Further improvement in the FSA's assessment of the robustness of banks' processes such as loan classification, impairment determination, and valuation practices, introduction of a proactive intervention framework, and greater level of involvement and engagement of FSA senior 
management in the supervision of individual banks and insurers is needed. Plans to enhance these aspects of supervision are welcome. As in many other countries, U.K. insurers generally weathered the recent financial crisis better than banks. Going forward, the FSA needs to monitor closely potential systemic risks from insurers engaging in 'bank like' activities and their interconnections with the banking sector. It is also important that the regulatory authority be provided with enforcement and resolution powers at the holding company level complemented with adequate checks and balances, in particular strong supervision, to avoid moral hazard.

The United Kingdom lags behind many other countries in standards for the public disclosure of financial sector data. To enable market discipline, the FSA should enforce publication of regular and comparable data on an institution basis for banks, insurance companies, and securities firms, including data from prudential returns, as appropriate.

\section{Progress has been made in addressing the too-important-to-fail problem, but more} needs to be done. Regulatory ratios have been strengthened and a bank levy on wholesale funding has been introduced. Ring-fencing of retail operations and the establishment of depositor preference, as proposed by the Independent Commission on Banking (ICB), will improve resolvability of the retail entity. However, ring-fencing must be weighed against the costs of such an approach and does not necessarily improve resolvability of the whole entity unless complemented by measures that improve loss-absorption capacity (capital and liquidity surcharges, contingent capital, debt subject to bail-in), recovery and resolution plans, and cross-border resolution arrangements. International collaboration will be critical for progress, and the U.K. authorities should continue exercising leadership on these matters.

The transition to the "triple peak" model risks diversion of resources from efforts to enhance supervision of the financial sector, which is still in recovery mode. The reform proposals to clarify the mandates of the prudential regulator, financial conduct authority, and macroprudential authority are welcome. However, it is critical to build on the progress made on strengthening supervision of the banking and insurance sector. This may require additional supervisory resources - a combination of enhanced skills and additional staff.

\section{Oversight of investment banking activities as well as of core market infrastructure needs to be improved further in the new regulatory structure. The United Kingdom is a financial markets hub and a major home and host country to bank and nonbank financial institutions. Oversight of investment banking and trading activities are a challenge, given the limitations to what the United Kingdom can do alone, particularly with respect to institutions that it hosts, such as branches of foreign bank entities. Without intensive supervision of investment bank risk taking, domestic and global financial stability cannot be assured. Gaps in this domain must be addressed through international cooperation, in particular across the key financial centers. It is critical that financial market infrastructure, including Central Counterparties (CCPs), also maintain robust prudential and risk-management standards and that contingency plans are put in place to deal with potential failures.}




\section{Table 1. United Kingdom FSAP Update: Main Recommendations}

\begin{tabular}{|c|c|c|}
\hline Recommendations and Authority Responsible for Implementation & Priority & Timeframe $^{11}$ \\
\hline \multicolumn{3}{|l|}{ Overall Financial Sector Oversight } \\
\hline $\begin{array}{l}\text { Revise the legal framework to clarify mandates and include a specific financial } \\
\text { stability mandate for the prudential authorities (Tripartite). }\end{array}$ & High & Immediate \\
\hline $\begin{array}{l}\text { Amend legislation to allow for regulatory power over holding companies of } \\
\text { regulated entities (Her Majesty's Treasury (HMT)). }\end{array}$ & High & Near term \\
\hline $\begin{array}{l}\text { Enhance resources for supervision of banks, insurers and securities firms based } \\
\text { on the agreed-upon supervisory operating model and the new macro-prudential } \\
\text { overlay (Tripartite). }\end{array}$ & High & Near term \\
\hline $\begin{array}{l}\text { Establish a forum for ensuring good governance and coordination among } \\
\text { organizations in the new regulatory structure (HMT). }\end{array}$ & High & Near term \\
\hline $\begin{array}{l}\text { Enforce public disclosure by banks, insurance and securities firms, including } \\
\text { publishing prudential returns as appropriate (FSA). }\end{array}$ & High & Near term \\
\hline \multicolumn{3}{|l|}{ Banking Oversight } \\
\hline $\begin{array}{l}\text { Enhance supervision by: conducting detailed reviews of credit and market risk } \\
\text { assessment by banks, and verification and selected model replication reviews on } \\
\text { a proactive basis; better integrating specialist work into the supervision program; } \\
\text { and enhancing peer analysis (FSA). }\end{array}$ & High & Near term \\
\hline $\begin{array}{l}\text { Adopt a proactive intervention framework through triggers for contacts and } \\
\text { coordination actions with other authorities and amend legislation as needed } \\
\text { (FSA). }\end{array}$ & Medium & Medium term \\
\hline $\begin{array}{l}\text { Develop a comprehensive plan to enhance prudential reporting and conduct a } \\
\text { review to deliver a more systematic approach to data quality (FSA). }\end{array}$ & High & Near term \\
\hline \multicolumn{3}{|l|}{ Insurance Sector Oversight } \\
\hline $\begin{array}{l}\text { Extend the new intrusive risk-based approach to supervision to a wider range of } \\
\text { insurers (FSA). }\end{array}$ & High & Near term \\
\hline $\begin{array}{l}\text { Increase the frequency and number of randomly conducted "transaction } \\
\text { examinations" for both the largest and some smaller insurers (FSA). }\end{array}$ & Medium & Medium term \\
\hline \multicolumn{3}{|l|}{ Securities Markets Oversight } \\
\hline $\begin{array}{l}\text { Clarify in legislation that the remit of the conduct authority includes market } \\
\text { integrity and transparency to ensure adequate emphasis on issues other than } \\
\text { consumer protection (HMT). }\end{array}$ & High & Immediate \\
\hline $\begin{array}{l}\text { Increase intensity of supervision with greater use of "bottom up" analysis of firm } \\
\text { operations using on-site examinations, including thematic work, to supplement } \\
\text { the "top down" risk analysis (FSA). }\end{array}$ & High & Medium term \\
\hline \multicolumn{3}{|l|}{ Payments and Securities Systems Oversight } \\
\hline $\begin{array}{l}\text { Ensure that sufficient and reliable funding options are in place for central } \\
\text { counterparties (CCPs), including committed credit lines subject only to } \\
\text { presentment (Bank of England (BoE), FSA). }\end{array}$ & High & Near term \\
\hline Develop contingency plans to deal with a potential failure of a CCP (BoE, FSA). & High & Near term \\
\hline $\begin{array}{l}\text { Offer central bank settlement to CCPs that have been classified as systemic } \\
\text { institutions (BoE). }\end{array}$ & Medium & Medium term \\
\hline $\begin{array}{l}\text { Establish close monitoring of concentration of banks' payment and settlements } \\
\text { activities (BoE, FSA). }\end{array}$ & Medium & Near term \\
\hline $\begin{array}{l}\text { Undertake a unified assessment of the real time gross settlement (RTGS) } \\
\text { infrastructure, including an assessment of the finality of transactions (BoE). }\end{array}$ & High & Medium term \\
\hline \multicolumn{3}{|l|}{ Crisis Management } \\
\hline $\begin{array}{l}\text { Establish appropriate resolution tools and framework for potentially systemically } \\
\text { important nonbank firms that are not covered by the Special Resolution Regime } \\
\text { (Tripartite). }\end{array}$ & Medium & Medium term \\
\hline
\end{tabular}

$1 /$ "Immediate" is within one year; "near-term" is $1-3$ years; "medium-term" is $3-5$ years. 


\section{INTRODUCTION}

1. The United Kingdom is both home and host to large domestic and international financial institutions. International foreign bank subsidiaries and branches hold half of U.K. banking assets, while U.K.-owned banks have over half of their assets outside the country. Overall, these institutions hold about $£ 11$ trillion of assets in the United Kingdom and globally, equal to about nine times GDP, of which U.K. banks account for assets equivalent to five times GDP. The U.K. insurance industry is the third largest in the world, after the United States and Japan. The United Kingdom is an important host to the global funds industry and to derivatives business and plays a significant role in cross-border trading and clearing (Table 2). Hence, U.K. financial institutions and market infrastructure are widely exposed to stresses originating from elsewhere in the world and also act as a conduit of shocks domestically and to the global financial system.

2. The U.K. banking system evolved intensively after 2000 in ways that made it more vulnerable to adverse shocks. The banks became larger, highly complex and leveraged, and relied increasingly on short-term wholesale funding (Figure 1). The trading book displaced loans as the most important balance sheet asset, reducing the importance of net interest income (Box 1). Financial activity was concentrated in a small set of institutions highly interconnected to other developed financial systems. Actual leverage was greater than was apparent, in part because regulatory requirements did not capture key risks.

\section{The crisis revealed major fault lines in the U.K. financial sector and its} regulatory framework. The heavy reliance on market discipline and the assumption of a wide dispersion of risks proved to be inadequate. Substantial risks posed by large, complex, and interconnected financial institutions crystallized, exposing weaknesses in the oversight framework that had enabled the expansion of their reach and complexity, both domestically and internationally (Box 2).

\section{Against this background, this report concentrates on two interrelated themes:}

- $\quad$ Crisis implications, the current soundness of the financial system, and potential risks and vulnerabilities; and

- Necessary improvements to the financial sector oversight framework and addressing the too-important-to-fail (TITF) problem.

5. The report is structured as follows. It first discusses the post-crisis financial conditions and analyzes the risks and vulnerabilities. It then evaluates the existing regulatory, supervisory, and crisis management frameworks and provides recommendations on how to address the shortcomings in the context of the ongoing deliberations on global financial sector reforms. 
Table 2. United Kingdom: Global Market Share in Financial Services, as at June 2011

\begin{tabular}{|c|c|}
\hline Products & $\begin{array}{l}\text { U.K. Market Share } \\
\text { (In percent unless } \\
\text { stated otherwise) }\end{array}$ \\
\hline \multicolumn{2}{|l|}{ International banking } \\
\hline Lending & 18 \\
\hline Borrowing & 21 \\
\hline European activities & 50 \\
\hline \multicolumn{2}{|l|}{ Insurance market } \\
\hline Global insurance premia & 3 global and 1 Europe \\
\hline \multicolumn{2}{|l|}{ Equities } \\
\hline Global foreign equity trading & 19 \\
\hline $\begin{array}{l}\text { Number of international Initial Public } \\
\text { Offerings (IPOs) }\end{array}$ & $\begin{array}{c}6 \text { IPOs with } 12 \text { percent } \\
\text { market share }\end{array}$ \\
\hline $\begin{array}{l}\text { Turnover on the London Stock } \\
\text { Exchange (LSE) }\end{array}$ & 4 of global turnover / 7 of global equity market capitalization \\
\hline \multicolumn{2}{|l|}{ Bonds } \\
\hline Euro-bonds secondary market & 70 percent of trading by bookrunners in London \\
\hline Securitization issuance & $6 \quad 2$ (behind the United States, 75 ) \\
\hline \multicolumn{2}{|l|}{ Fund management } \\
\hline Fund management (source of funds) & 2 (behind the United States, 50) \\
\hline Hedge fund assets & 2 (behind the United States, 68) \\
\hline Private equity investment value & 2 (behind the United States, 36) \\
\hline \multicolumn{2}{|l|}{ Derivatives } \\
\hline OTC interest rate derivatives & 46 (turnover) \\
\hline Exchange-traded derivatives & $\begin{array}{c}\text { Four derivative exchanges: New York Stock Exchange Liffe } \\
\text { is \#2. London Metals Exchange is \#1 for non-ferrous metals. } \\
\text { ICE Futures Europe is \#1 in Europe and \#2 worldwide for } \\
\text { energy products. }\end{array}$ \\
\hline \multicolumn{2}{|l|}{ Foreign exchange } \\
\hline Turnover & 37 \\
\hline \multicolumn{2}{|l|}{ Commodities } \\
\hline Commodity derivatives trading & \multirow{2}{*}{$\begin{array}{l}\text { London and New York are main international players } \\
\text { (Chicago is the biggest domestic player). } \\
\text { The London Bullion Market Associaiton (LBMA) is the largest } \\
\text { OTC market ahead of New York and Zurich and clears most } \\
\text { of the wholesale OTC trades. }\end{array}$} \\
\hline Bullion markets (gold/silver) & \\
\hline \multicolumn{2}{|l|}{ Carbon markets } \\
\hline Emission allowances & $\begin{array}{c}\text { The United Kingdom bought } 37 \text { percent of the Clean } \\
\text { Development Mechanism (CDM). London is a leading center } \\
\text { for energy brokers and carbon funds. The European Climate } \\
\text { Exchange (ECX) in London is dominant in the trading of } \\
\text { European Union (EU) Emissions Trading Scheme (ETS) } \\
\text { futures and options contracts. }\end{array}$ \\
\hline \multicolumn{2}{|l|}{ Maritime services } \\
\hline Marine insurance premium & $\begin{array}{l}\text { London is the leading center for } \\
\text { marine and aviation insurance. }\end{array}$ \\
\hline \multicolumn{2}{|c|}{$\begin{array}{l}\text { Leader in shipping finance (13), ship classification (18), ship-broking (30-50 percent) and legal } \\
\text { services. The International Maritime Organization is headquartered in London }\end{array}$} \\
\hline \\
\hline \multicolumn{2}{|c|}{$\begin{array}{l}\text { Largest number of "sharia compliant" banks (22), exchange-traded funds (7), law firms (20) among } \\
\text { Western countries; issued } 31 \text { sukuk on LSE. }\end{array}$} \\
\hline
\end{tabular}

Source: TheCityUK. 
Figure 1. United Kingdom: Bank Lending and Funding

Lending to commercial and real estate sectors increased rapidly in the run-up to the crisis.

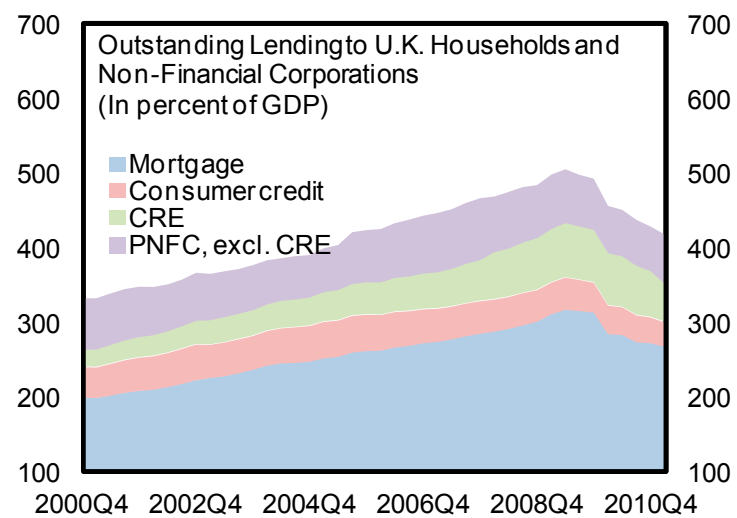

The reliance of wholesale funding increased, partly as a result..

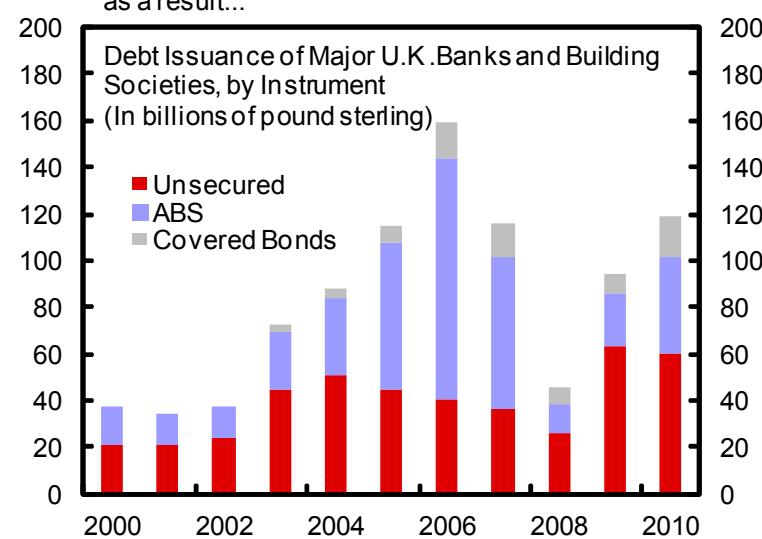

These trends have partialy reversed, but fund ing over the next few years remains a challenge..

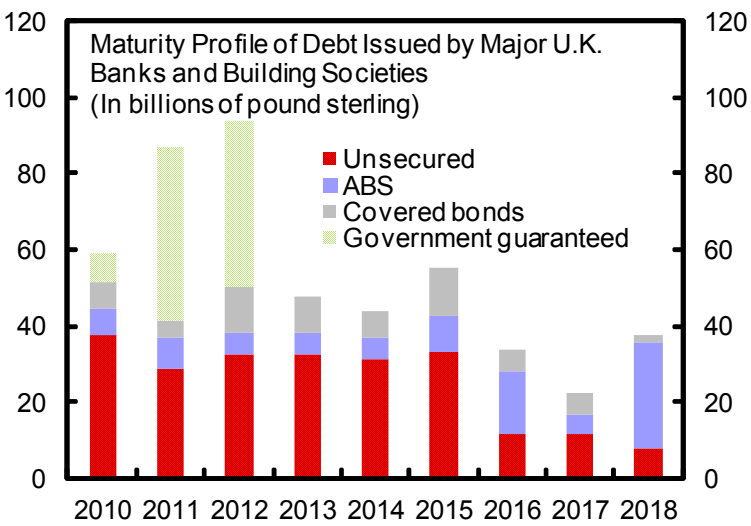

Between 2005 and 2008, growth in lending remained relatively stable while growth in deposits

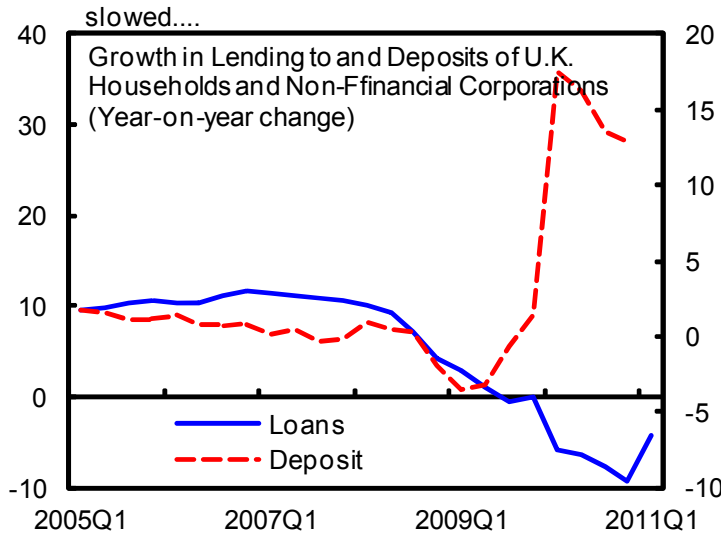

but the concurrent increase in leveraged positions was not adequately captured in the data.
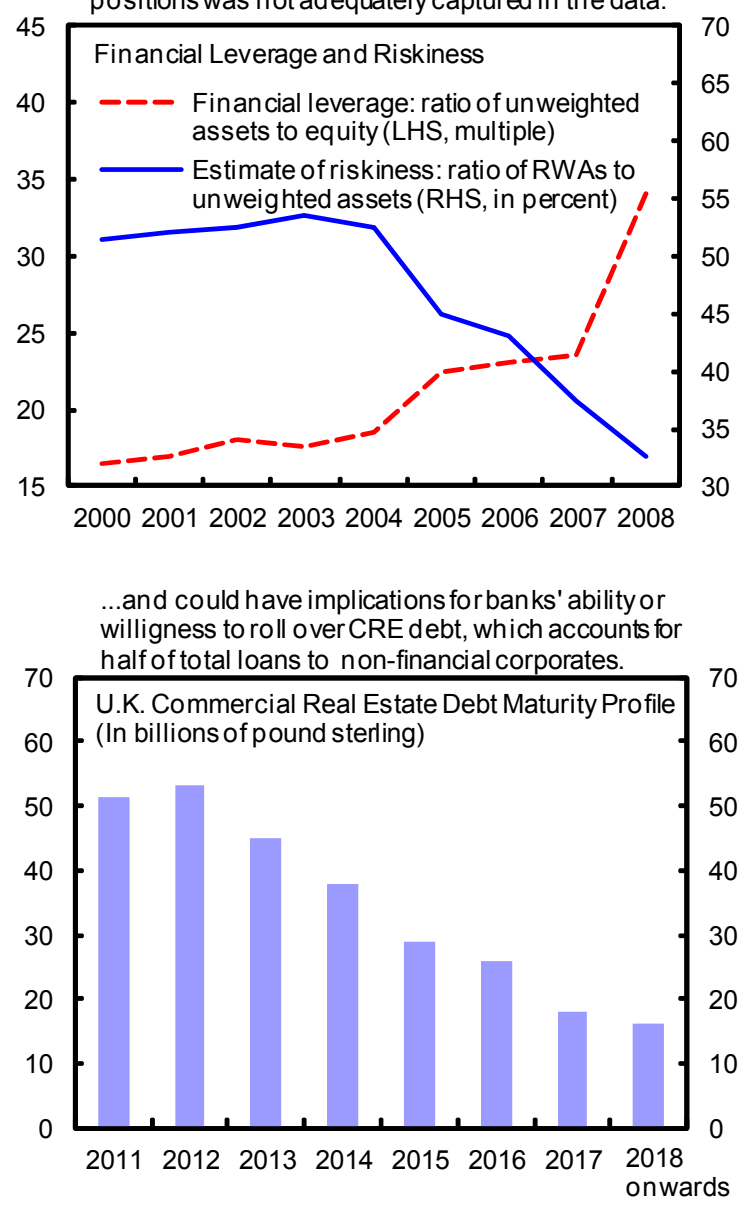

Sources: Bank of England (BoE), FSA calculations; CB Richard Ellis, De Montfort University; Dealogic DCM Analysis; financial statements of major U.K. banks; ICB; Office of National Statistics (ONS); and IMF staff calculations. 


\section{Soundness of the Financial System ANd Potential Risks}

\section{A. The Crisis}

6. The impact of the crisis on the U.K. banking sector was highly polarized. Some institutions emerged from the crisis virtually unscathed while others, including two of the six largest banks and several building societies, required extensive official support. This differentiation reflected their disparate business models and pre-crisis exposures (Figure 2 and Table 3). ${ }^{1}$ In particular, the reliance on wholesale funding ranged substantially, reflecting wide differences in loan-to-deposit ratios among institutions.

7. The insurance sector weathered the crisis relatively well. The introduction of risksensitive capital requirements ahead of Solvency II and the related adjustments to capital and investment in the aftermath of the 2003 insurance sector crisis resulted in a relatively solvent industry. While the impact of the global financial crisis reverberated through the industry, especially in the life insurance sector, the industry as a whole remained largely resilient.

8. The interbank and foreign exchange markets came under severe pressure during the crisis, necessitating policy interventions. The ability of U.K. banks to access interbank and wholesale funding markets depended on their underlying conditions - and perceptions of the counterparty risks they represented - but were also affected by the disruptions to the functioning of markets.

9. The U.K. authorities acted decisively and introduced policy measures to stabilize the financial system (Appendix II). These comprise liquidity support, including the Special Liquidity Scheme (SLS), which allows banks to swap their high-quality but illiquid mortgage-backed and other securities for U.K. treasury bills; the Credit Guarantee Scheme (CGS), which provides additional funding support; as well as an asset protection scheme (APS) against future credit losses; and an Asset Purchase Facility (APF) to purchase highquality assets from a broad range of corporates. Although banks are ahead of schedule in repaying official liquidity support, the government retains significant stakes in the financial sector after having injected a cumulative $£ 70$ billion of capital into several banks (including taking ownership of 41 percent and 83 percent of the total share capital of LBG and RBS, respectively). As a result, the net direct cost of fiscal support to the U.K. financial sector relative to GDP is one of the largest in the EU, after Ireland and Germany (Table 4).

\footnotetext{
${ }^{1}$ The analysis in this report focuses on the five major U.K.-owned banks, the biggest foreign-owned bank subsidiary and the largest building society (hereafter the "seven major U.K. banks"): Barclays, HSBC Group (HSBC), Lloyds Banking Group (LBG), RBS, Standard Chartered Bank (SCB), Santander U.K. and Nationwide. Together, these seven institutions account for 71 percent of total assets in the banking system, 80 percent of loans and close to 90 percent of retail deposits.
} 
Figure 2. Major U.K. Banks: Differentiated Geographic and Business Models

(As at end-2010, in percent of individual banks' revenues)

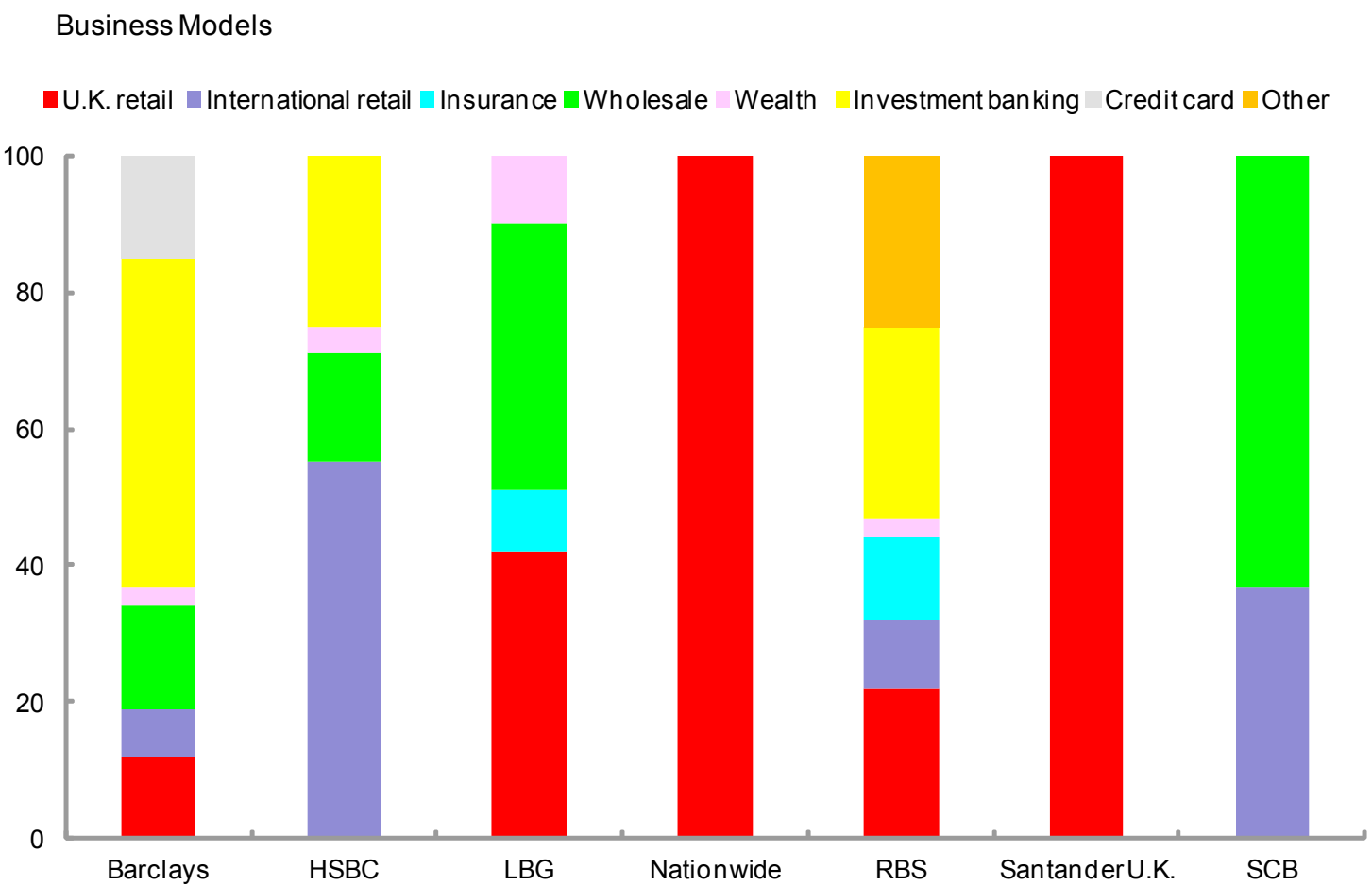

Geographic Footprints

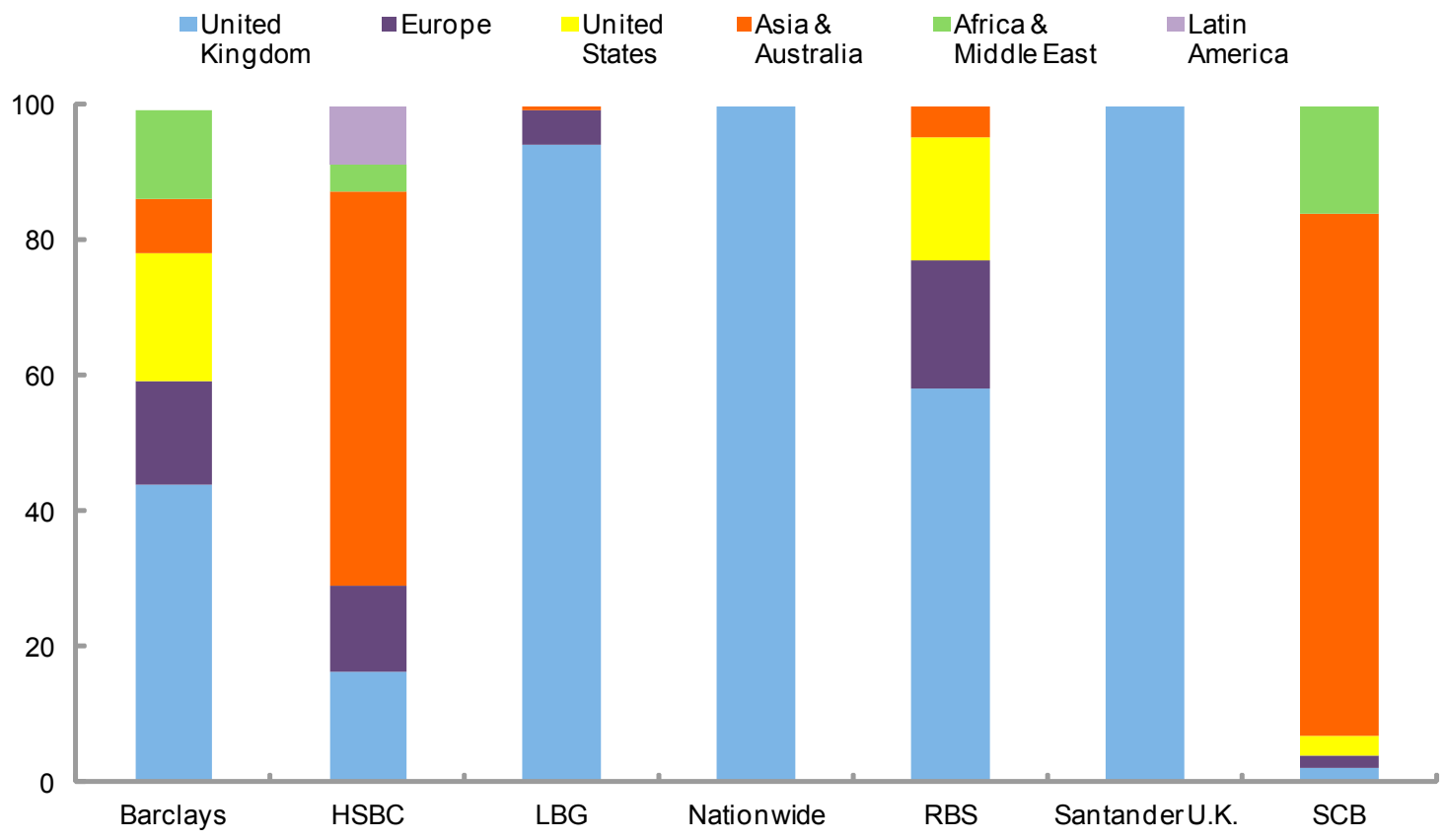

Sources: Bloomberg; individual banks' Annual Reports; and IMF staff estimates. 
Table 3. United Kingdom: Composition of the Banking System

\begin{tabular}{lccccc}
\hline \multicolumn{1}{c}{ Firm } & \multicolumn{3}{c}{ Assets } & & \multicolumn{2}{c}{ Loans and advances to customers 1/ } \\
\cline { 2 - 3 } Major U.K.-owned banks 2/ & $\begin{array}{c}\text { Amount } \\
\text { (Millions of GBP) }\end{array}$ & $\begin{array}{c}\text { Firm/Banking Sector } \\
\text { (Percent of total) }\end{array}$ & & $\begin{array}{c}\text { Amount } \\
\text { (Millions of GBP) }\end{array}$ & $\begin{array}{c}\text { Firm/Banking Sector } \\
\text { (Percent of total) }\end{array}$ \\
\hline Building societies and mutuals & $3,060,342$ & 66.4 & $2,303,115$ & 78.0 \\
Foreign-owned retail banks & 368,443 & 4.0 & 280,144 & 9.5 \\
Foreign investment banks & 495,220 & 5.4 & 302,694 & 10.2 \\
Total & $2,208,055$ & 24.2 & 67,462 & 2.3 \\
\hline
\end{tabular}

Sources: FSA; and BoE.

Note: The core stress test sample of the seven major U.K. banks represents 71.1 percent of banking sector assets and 89 percent of loans and advances to customers.

1/ Non-trading book. 


\section{Table 4. Selected Advanced Economies: Recovery of Outlays and Net Cost of Financial Sector Support 1/}

(Latest available data as at end-March 2011; in percent of 2010 GDP)

\begin{tabular}{lrcc}
\hline & Direct Support & Recovery & Net Direct Cost \\
\hline Belgium & & & \\
Ireland 2/ & 4.3 & 0.2 & 4.1 \\
Germany 3/ & 30.0 & 1.3 & 28.7 \\
Greece & 10.8 & 0.1 & 10.7 \\
Netherlands & 5.1 & 0.1 & 5.0 \\
Spain & 14.4 & 8.4 & 6.0 \\
United Kingdom & 2.9 & 0.9 & 2.0 \\
United States & 7.1 & 1.1 & 6.0 \\
& 5.2 & 1.8 & 3.4 \\
\hline
\end{tabular}

Source: Fiscal Monitor, IMF.

Note: Fiscal outlays of the central government. In addition, some countries may have supported financial institutions via fiscal outlays at the subnational level or through other public sector institutions. For example, in Germany, capital injections from the Laender and $\mathrm{KfW}$ (development bank) amount to 1.1 percent of GDP; in Belgium, financial sector support from regional government amount to 1.6 percent of GDP.

$1 /$ Cumulative since the beginning of the crisis based on the latest available data (ranging between end-December 2010 and end-March 2011).

2/ Direct support does not include asset purchases by the National Asset Management Agency, as these are not financed directly through the general government but with government-guaranteed bonds.

3/ Direct support includes an estimated amount of $€ 240$ billion ( $91 / 2$ percent of GDP) for asset purchases.

\section{B. Financial Sector Conditions in the Aftermath of the Crisis}

\section{U.K. banks have made progress in repairing their balance sheets (Table 5).}

Deleveraging was pursued through write-offs, capital-raising efforts, asset sales, reduced lending growth, and retrenchment of cross-border exposures, including to vulnerable European countries

(Figure 3). The combined total assets of the seven major U.K. banks fell 20 percent from 2008 to 2010 and risk-weighted assets by 7 percent (Figure 3). With deposits growing faster than loans since 2009, the funding gap — albeit still large — is declining and the use of wholesale funding has been reduced significantly (Figure 4). The Core Tier 1 ratios of all the major U.K. banks are in double-digit territory (Figure 5), which compares well with most European peers.

11. However, some loan portfolios remain fragile and further provisioning is necessary. Banks' profitability in 2010 was largely attributable to the significant drop in provisions (Figure 6). This partly reflects model-based approaches used by some banks for provisions that 
may have relied on overoptimistic assumptions about interest rates, inflation, unemployment, and house prices. With coverage ratios trending down close to 50 percent on average for the sector amid a wide dispersion across banks, there is limited cushion to absorb further losses that may affect banks, should the economy take a turn for the worse.

\section{Furthermore, lender forbearance — confirmed in discussions with supervisors and} banks - and poor data quality may mask and delay recognition of the true extent of risks. This problem is of particular concern in the real estate sector. While some degree of restructuring is acceptable for particular assets and debtors for a reasonable period of time, it is not yet clear whether this approach is masking true impairment and whether restructured assets are properly accounted for and monitored. The FSA recently conducted a thematic review to determine the extent of forbearance among banks and introduced formal guidance regarding reporting and classification of restructured loans and provisioning.

13. Funding costs are likely to remain elevated for some banks. Deleveraging and deposit mobilization are reducing the funding gap, but banks have substantial funding needs, amounting to about $£ 400$ billion through end 2012 (see Figure 4), ${ }^{2}$ including the expiration of official funding facilities. A number of short-term and structural factors can be expected to put upward pressure on the cost of wholesale funding for U.K. banks: (i) the rollover of cheaper debt (in particular official funding facilities) into more expensive new debt at a time when sovereign debt issuance will be elevated; (ii) regulatory uncertainties regarding the status of senior secured debt holders in a "bail in" and possible structural changes as a result of the ongoing Independent Commission on Banking (ICB) deliberations, as well as overseas regulatory changes limiting some traditional sources of funding (U.S. money market mutual funds); and (iii) potential changes in institutional investor preferences (e.g., pressure on traditional longer-term investors such as insurance companies and pension funds to shorten durations) due to expectations of increase in sovereign yields and regulatory changes (such as Solvency II for the insurance sector).

\section{The two large institutions with government stakes made progress in the} implementation of their restructuring programs, but challenges remain. These banks, RBS and LBG, are now in the third year of a five-year restructuring plan and are ahead of the targets set by the U.K. authorities and the European Commission (EC) state aid rules. Through a combination of run-offs and sales, the two banks shed a combined $£ 235$ billion of assets since 2008 and have repaid a substantial amount of their use of official funding facilities. They have also reduced their reliance on wholesale funding and lengthened the duration of their liabilities. However, they still face significant internal execution risks and are particularly vulnerable to circumstances that may derail planned further asset reductions or disrupt wholesale funding markets. Given the substantial amount of government stakes in these two institutions, divestment

\footnotetext{
${ }^{2}$ Bank of England, 2010, Financial Stability Report (London, December 2010).
} 
by the state will take time and will depend critically on the continued implementation of their restructuring programs.

15. Separately, the financial condition of the insurance sector has generally improved post-crisis. Life insurance activity continues to recover following a period of weakness during the crisis and is back to the levels of production seen before the crisis. The nonlife insurance is recently reporting a slight premium decrease, mainly due to the economic downturn. About 10 percent of life insurers and 25 percent of nonlife insurers remain under regulatory observation, with Pillar II solvency ratios less than 130 percent.

\section{Macroeconomic and Financial Risks}

\section{The IMF's central scenario projects a moderate economic recovery and a gradual} return to the inflation target. A soft housing market, headwinds from fiscal consolidation, and the ongoing process of household and bank balance sheet repair are expected to continue to weigh on growth. Led by private sector investment and net exports, real GDP growth is expected to accelerate gradually to around 2.5 percent over the medium term. Inflation is projected to remain above 4 percent due to commodity price and tax hikes for most of 2011 and return to the 2 percent target by end-2012 as these transitory factors dissipate. The current mix of tight fiscal and accommodative monetary policies is seen as appropriate. The central scenario incorporates a gradual tightening of monetary policy with the resumption of growth (Table 6).

\section{However, the central scenario is susceptible to a number of macroeconomic and financial risks, with implications for the banking system:}

- $\quad$ Sluggish growth. There is uncertainty around the medium-term growth outlook, as headwinds from balance sheet repair by households, banks, and the public sector could turn out to be stronger than expected.

- $\quad$ Interest rate increases. Higher-than-expected inflation could force faster policy rate hikes than envisaged in the baseline. Households remain heavily indebted and bank losses could surge if asset quality deteriorates as borrowers increasingly struggle to service variable rate loans. The FSAP's analysis shows that low-income households are most sensitive to real interest rate and income shocks (Box 3).

- $\quad$ Reduced fiscal space to cope with future adverse shocks. The financial crisis brought about a sharp increase in government debt.

- $\quad$ A new sharp downturn in the residential housing market. The price-to-income ratio remains 30 percent above its historical average (based on OECD data), leaving household balance sheets vulnerable to further declines in house prices.

- $\quad$ Financial distress in the commercial real estate (CRE) sector. Prices remain substantially below their peak, leaving a number of borrowers with negative equity and in breach of 
loan-to-value covenants. The FSAP's analysis shows that macroeconomic shocks would disproportionately affect this sector (Box 3 ).

- $\quad$ Spillovers from external financial market shocks. Sustained disruptions in wholesale funding markets due to external shocks could create funding shortages in the system.

- Depending on their geographic footprint, banks are exposed to realization of risks in other regions such as the Eurozone (where risks are rising sharply), Asia, and Latin America. Direct and indirect exposures to the private and public sector in the three Eurozone countries with EU/IMF-supported programs (Greece, Ireland, and Portugal) amount to $\$ 173$ billion (approximately $£ 111$ billion; 2.8 percent of total assets), with the bulk of this exposure being to Ireland at $\$ 135$ billion ( $£ 86$ billion). Additionally, exposures to Spain amount to $\$ 107$ billion ( $£ 69$ billion). As documented in the BoE’s June 2011 Financial Stability Report, major U.K. banks' claims on Ireland and Spain, primarily to the nonbank private sector, is equivalent to about 50 percent of their Core Tier 1 capital (split evenly between the two countries), while lending to Italy accounts for a significantly smaller share of capital (about 8.5 percent). Further, some banks in core European countries may be vulnerable to shocks emanating from these countries, which in turn may affect U.K. banks due to their substantial exposures to those banks.

\section{The analysis of banking sector conditions and stress tests aim to capture the most} salient risks to the U.K. banking system (Figure 7). Solvency stress tests have been conducted on the major U.K. banks against the Basel III hurdle rates, while the FSA Interim Capital Regime requirements (see discussion on banking supervision below) are also discussed. Separately, liquidity stress tests were undertaken for a larger set of institutions, including foreign subsidiaries of retail and investment banks as well as a broader group of building societies, incorporating quasi-Basel III measures.

\section{The findings support the current supervisory focus in the United Kingdom to} require banks to build up adequate capital and liquidity buffers. They suggest that the banking system would be resilient to most of the macro-financial risks described above, but that there are pockets of vulnerabilities that need to be addressed: ${ }^{3}$

- $\quad$ Banks' solid capital buffers have reduced solvency concerns to a low-probability confluence of adverse macroeconomic developments. The analysis suggests that the substantial recapitalization of the U.K. banking sector, including by the state, and the derisking of balance sheets have been critical in boosting the solvency of the system. However, an important caveat is that lender forbearance - which could not be accurately estimated in the stress tests due to lack of data - may have masked the extent of credit

\footnotetext{
${ }^{3}$ See FSAP Technical Note, "Stress Testing the Banking Sector," for a more detailed discussion.
} 
risk in some institutions, especially given the high indebtedness of the household and commercial real estate sectors. ${ }^{4}$

Table 5. United Kingdom: Financial Soundness Indicators 1/

(In percent)

\begin{tabular}{|c|c|c|c|c|c|}
\hline & Dec 2008 & Jun 2008 & Dec 2009 & Jun 2010 & Dec 2010 \\
\hline \multicolumn{6}{|l|}{ Core FSIs for deposit takers } \\
\hline Regulatory capital to risk-weighted assets & 12.9 & 13.3 & 14.8 & 15.0 & 15.9 \\
\hline Regulatory Tier 1 capital to risk-weighted assets & 9.6 & 10.2 & 11.6 & 12.4 & n.a. \\
\hline Nonperforming loans net of provisions to capital & 8.6 & 19.9 & 14.8 & 16.5 & n.a. \\
\hline Nonperforming loans to total gross loans & 1.6 & 3.3 & 3.5 & 3.7 & 4.0 \\
\hline \multicolumn{6}{|l|}{ Sectoral distribution of loans to total loans } \\
\hline Residents & 49.5 & 52.6 & 55.3 & 52.7 & n.a. \\
\hline Deposit-takers & 11.8 & 12.2 & 16.6 & 12.3 & n.a. \\
\hline Central bank & 0.0 & 0.0 & 0.0 & 0.0 & n.a. \\
\hline Other financial corporations & 15.6 & 16.0 & 15.4 & 14.7 & n.a. \\
\hline General government & 0.2 & 0.3 & 0.2 & 0.2 & n.a. \\
\hline Nonfinancial corporations & 8.4 & 9.6 & 8.7 & 8.5 & n.a. \\
\hline Other domestic sectors & 13.5 & 14.6 & 14.4 & 17.1 & n.a. \\
\hline Nonresidents & 50.5 & 47.4 & 44.7 & 47.3 & n.a. \\
\hline Return on assets & -0.4 & -0.1 & 0.1 & 0.3 & 0.2 \\
\hline Return on equity & -10.3 & -2.0 & 2.6 & 6.1 & 3.9 \\
\hline Interest margin to gross income & 65.4 & 44.7 & 44.1 & 41.9 & n.a. \\
\hline Noninterest expenses to gross income & 84.3 & 60.2 & 62.4 & 58.5 & n.a. \\
\hline Liquid assets to total assets & 29.8 & 18.5 & 20.5 & 19.9 & n.a. \\
\hline Liquid assets to short-term liabilities & 42.3 & 41.4 & 38.0 & 39.5 & n.a. \\
\hline Net open position in foreign exchange to capital & 29.2 & 29.2 & 1.0 & 4.5 & n.a. \\
\hline \multicolumn{6}{|l|}{ Encouraged FSIs for deposit takers } \\
\hline Capital to assets & 4.4 & 4.8 & 5.4 & 5.0 & 5.4 \\
\hline Large exposures to capital & n.a. & n.a. & n.a. & n.a. & n.a. \\
\hline \multicolumn{6}{|l|}{ Geographical distribution of loans to total loans } \\
\hline Domestic economy & 56.7 & 58.5 & 60.9 & 52.7 & n.a. \\
\hline Advanced economies, excluding China & 36.8 & 35.3 & 33.2 & 33.8 & n.a. \\
\hline Other emerging market and developing countries, including & 6.5 & 6.3 & 6.0 & 13.4 & n.a. \\
\hline Africa & 1.2 & 1.3 & 1.2 & 1.2 & n.a. \\
\hline Of which: Sub-Sahara & 1.2 & 1.3 & 1.2 & 1.2 & n.a. \\
\hline Central and Eastern Europe & 0.4 & 0.4 & 0.0 & 0.5 & n.a. \\
\hline Commonwealth of Independent States and Mongolia & 0.1 & 0.2 & 0.1 & 0.2 & n.a. \\
\hline Developing Asia, including China & 2.2 & 1.9 & 2.1 & 2.6 & n.a. \\
\hline Middle East & 1.3 & 1.2 & 1.2 & 1.3 & n.a. \\
\hline Western Hemisphere & 1.3 & 1.3 & 1.3 & 1.5 & n.a. \\
\hline Gross asset position in financial derivatives to capital & 937.3 & 624.3 & 705.2 & 766.9 & n.a. \\
\hline Gross liability position in financial derivatives to capital & 924.8 & 609.0 & 695.0 & 759.4 & n.a. \\
\hline Trading income to total income & -3.6 & 15.7 & 17.5 & 21.4 & n.a. \\
\hline Personnel expenses to noninterest expenses & 43.5 & 47.7 & 44.3 & 49.2 & n.a. \\
\hline Spread between reference lending and deposit rates (basis points) & n.a. & n.a. & n.a. & 225.0 & n.a. \\
\hline Spread between highest and lowest interbank rates (basis points) & n.a. & n.a. & n.a. & n.a. & n.a. \\
\hline Customer deposits to total (noninterbank) loans & 94.5 & 97.9 & 100.8 & 104.5 & n.a. \\
\hline Foreign-currency-denominated loans to total loans & 61.2 & 55.9 & 53.9 & 55.0 & n.a. \\
\hline Foreign-currency-denominated liabilities to total liabilities & 73.8 & 69.0 & 66.8 & 68.6 & n.a. \\
\hline Net open position in equities to capital & 52.6 & 50.4 & 85.9 & 74.3 & n.a. \\
\hline
\end{tabular}

\footnotetext{
${ }^{4}$ The BoE Financial Stability Report (June 2011) estimates that, as an upper bound, 12 percent of U.K. residential mortgages could be receiving some kind of forbearance, while 12 percent of commercial property loans were in breach of financial covenant as at end-2010, but had not been declared in default.
} 


\section{Table 5. United Kingdom: Financial Soundness Indicators (Concluded)}

\begin{tabular}{|c|c|c|c|c|c|}
\hline & Dec 2008 & Jun 2008 & Dec 2009 & Jun 2010 & Dec 2010 \\
\hline \multicolumn{6}{|l|}{ Other financial corporations } \\
\hline Assets to total financial system assets & 36.4 & n.a. & n.a. & n.a. & n.a. \\
\hline Assets to Gross Domestic Product (GDP) & 979.9 & n.a. & n.a. & n.a. & n.a. \\
\hline \multicolumn{6}{|l|}{ Nonfinancial corporations } \\
\hline Total debt to equity & 209.3 & 209.3 & n.a. & n.a. & n.a. \\
\hline Return on equity & 6.9 & 6.9 & 5.8 & 6.2 & n.a. \\
\hline Earnings to interest and principal expenses & 518.8 & 518.8 & 843.2 & 890.3 & n.a. \\
\hline Net foreign exchange exposure to equity & n.a. & n.a. & n.a. & n.a. & n.a. \\
\hline Number of bankruptcy proceedings initiated & n.a. & n.a. & n.a. & 2,072 & n.a. \\
\hline \multicolumn{6}{|l|}{ Households } \\
\hline Household debt to GDP & 217.0 & 224.2 & 217.5 & 215.8 & n.a. \\
\hline Household debt service and principal payments to income & n.a. & n.a. & n.a. & n.a. & n.a. \\
\hline \multicolumn{6}{|l|}{ Market liquidity } \\
\hline Average bid-ask spread in the securities market & n.a. & n.a. & n.a. & n.a. & n.a. \\
\hline Average daily turnover ratio in the securities market & n.a. & n.a. & n.a. & n.a. & n.a. \\
\hline \multicolumn{6}{|l|}{ Real estate markets } \\
\hline Residential real estate prices (annual percentage increase) & n.a. & n.a. & n.a. & 8.4 & n.a. \\
\hline Commercial real estate prices (annual percentage increase) & n.a. & n.a. & n.a. & 15.0 & n.a. \\
\hline Residential real estate loans to total loans & 11.7 & 14.8 & 14.5 & 16.9 & n.a. \\
\hline Commercial real estate loans to total loans & 4.9 & 5.4 & 5.0 & 4.9 & n.a. \\
\hline
\end{tabular}

Source: IMF.

1/ The indicators in the table are only available collectively from December 2008 onwards.

Figure 3. U.K. Banking System: Composition of Assets and Risk-Weighted Assets

(In trillions of pound sterling)

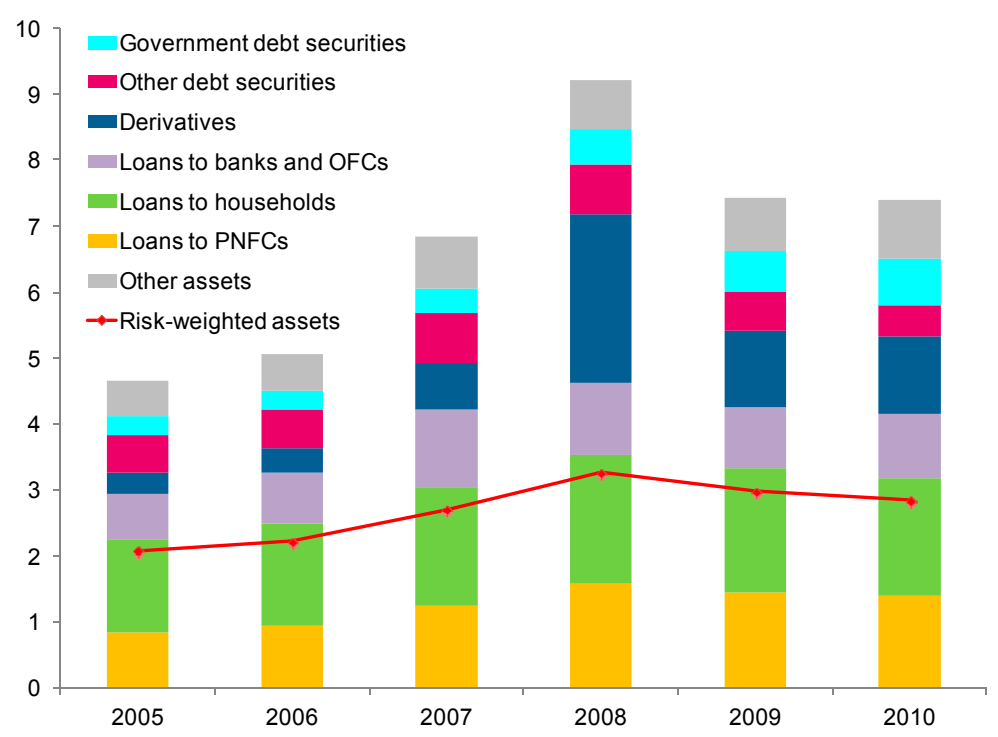

Source: BoE. 
Figure 4. United Kingdom: Funding Issuance by Banks and Their Maturity Profiles

(In billions of U.S. dollars)
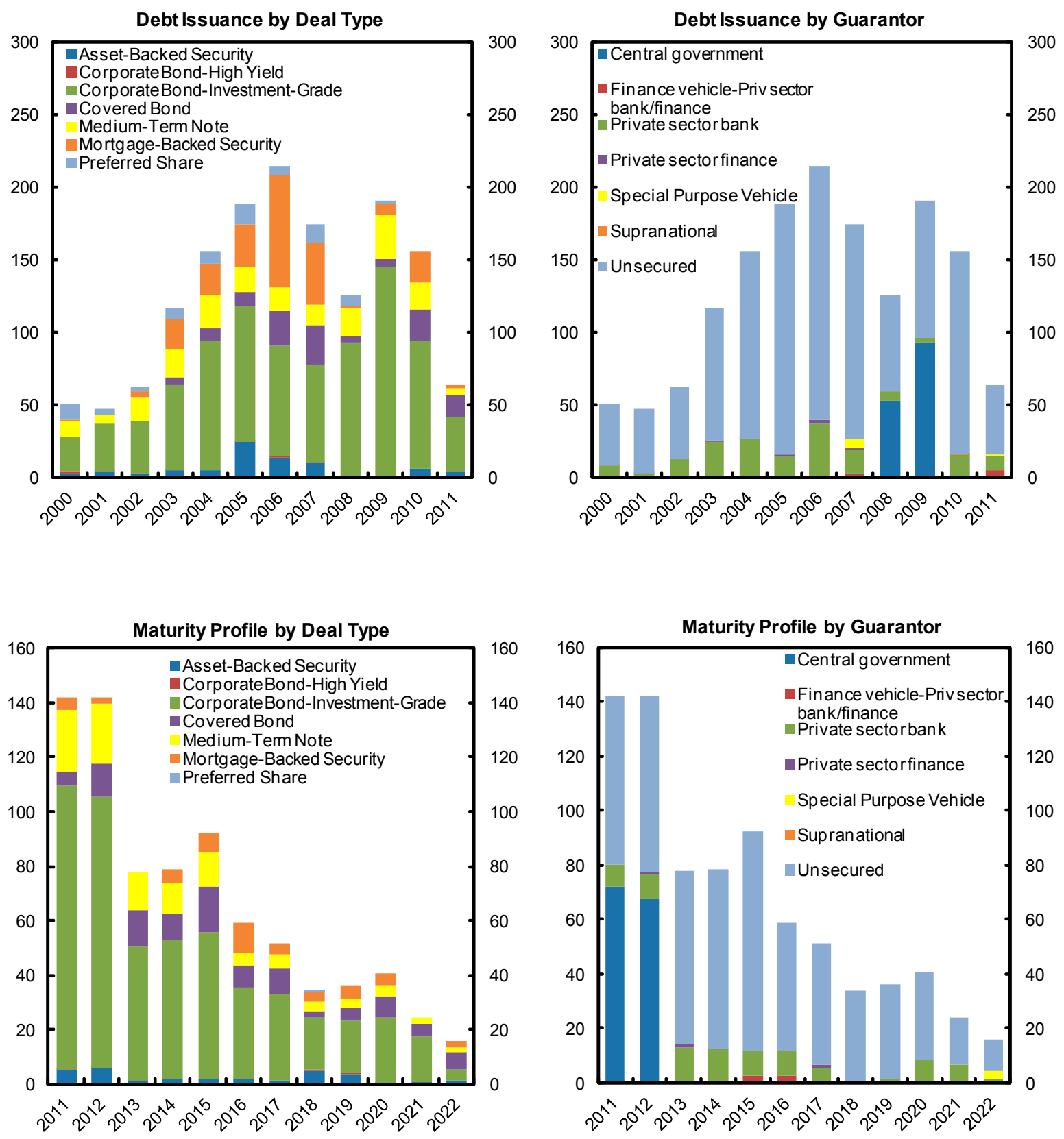

Source: Dealogic. 
Figure 5. United Kingdom: Financial Soundness of Major Banks 1/

(In percent)
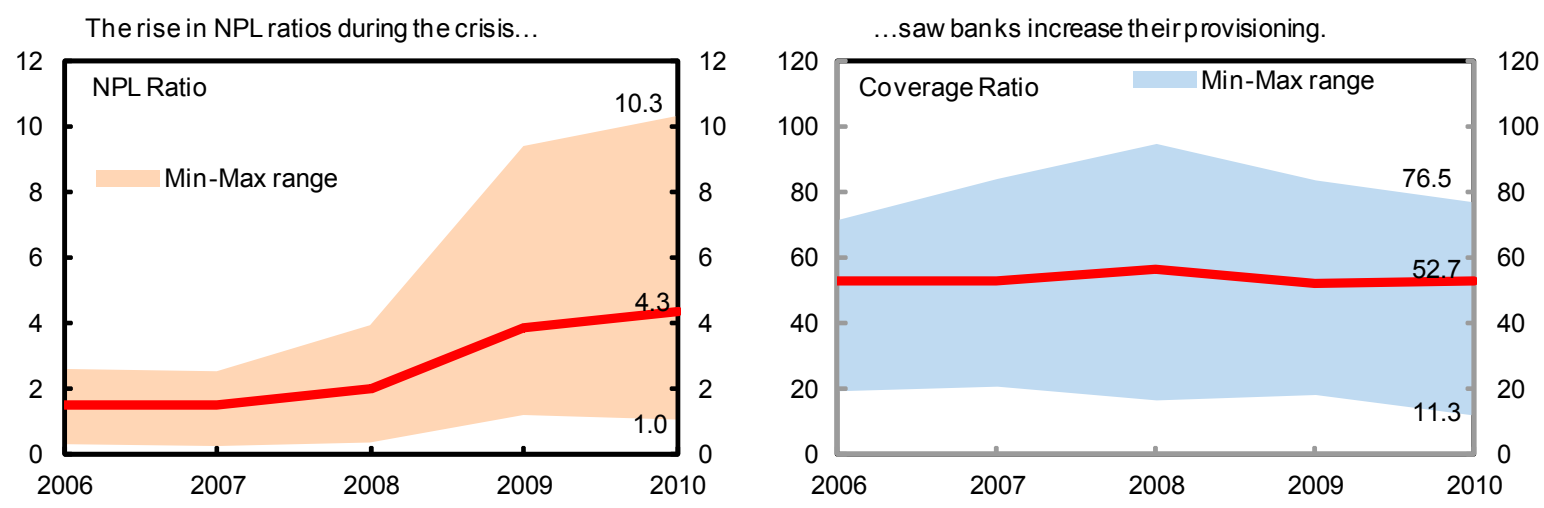

Capital adequacy continues to improve...
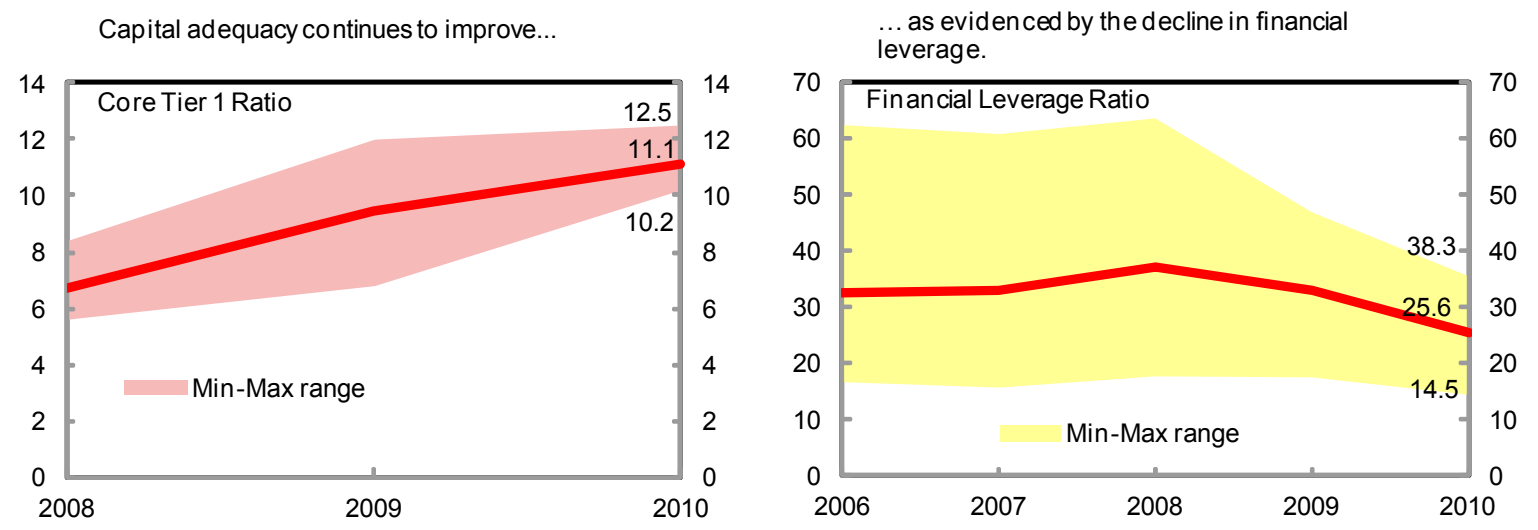

The fund ing gap has narrowed somewhat...

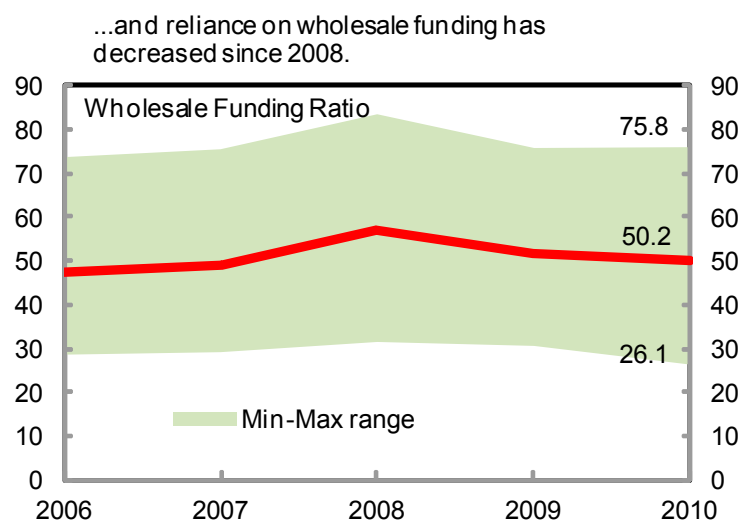

Sources: Annual reports of individual banks; and IMF staff estimates.

1/ Sample comprises Barclays, HSBC, LBG, Nationwide, RBS, SCB and Santander U.K. 
Figure 6. United Kingdom: Banks' Asset Quality

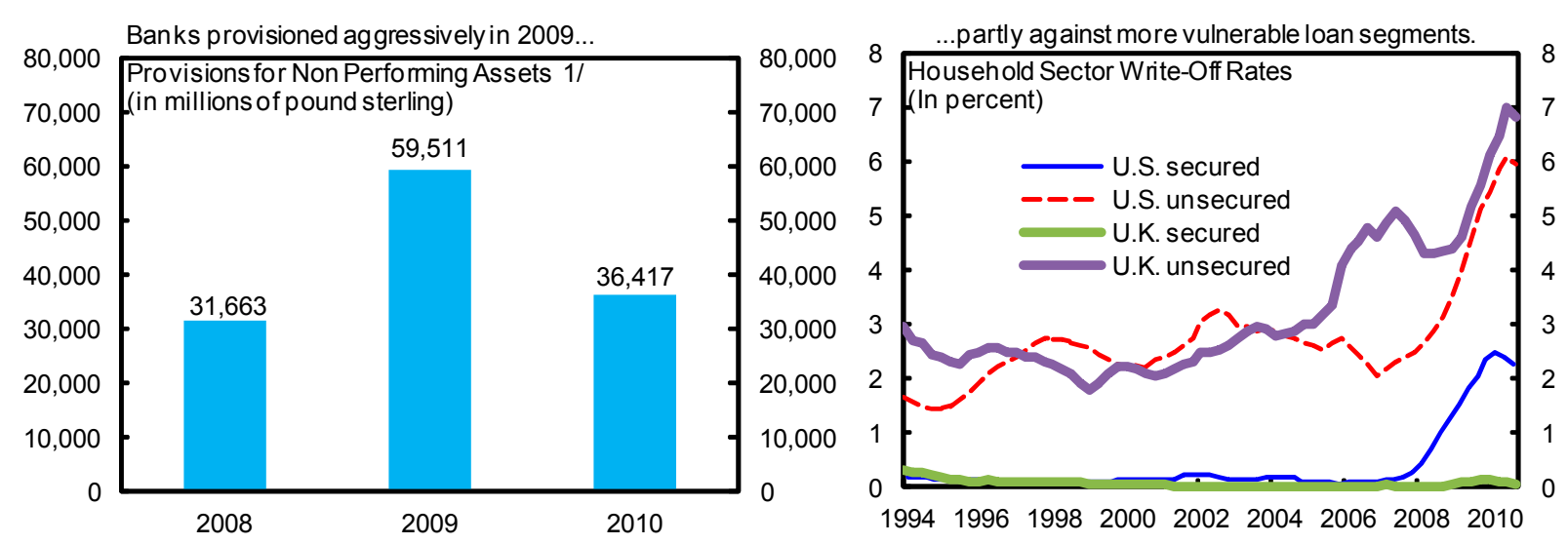

Lender forebearance provided some relief that may prove to be short-lived...
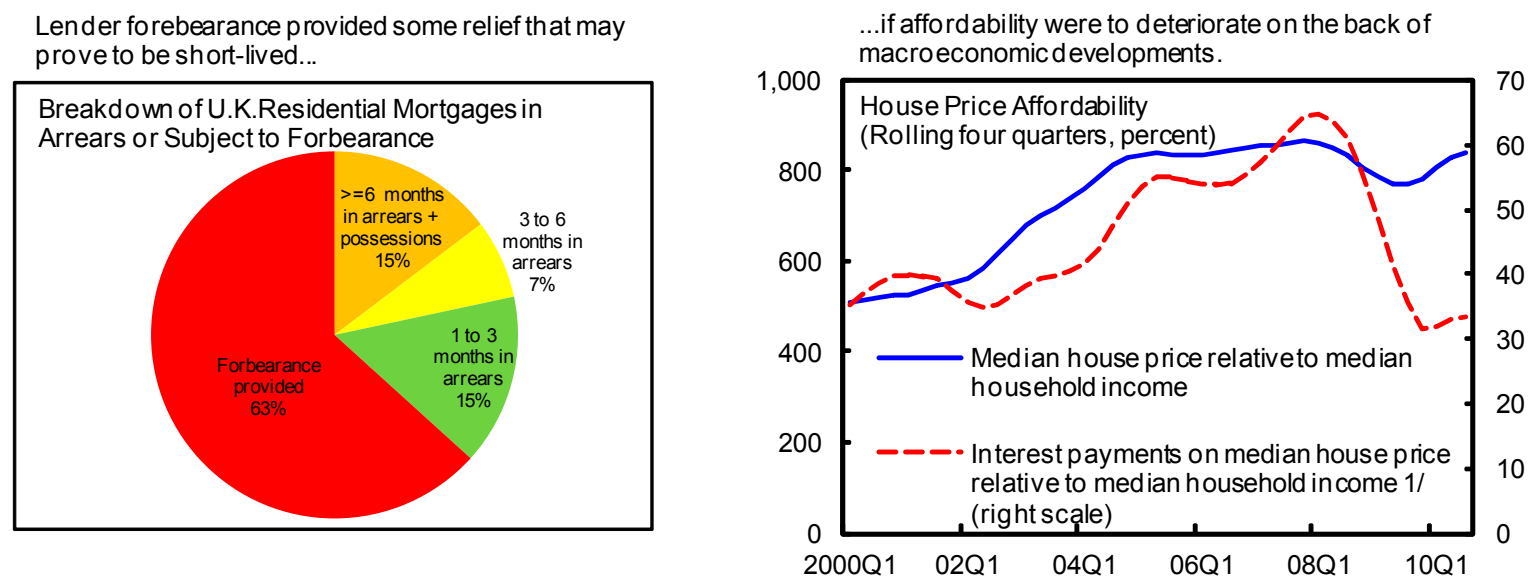

The corporate sector has been largely resilient

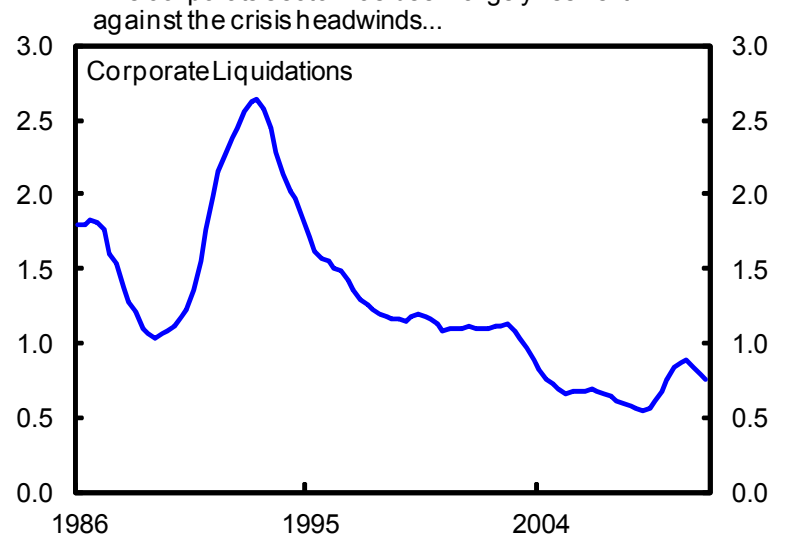

...but the CRE sector remain s highly vulnerable.

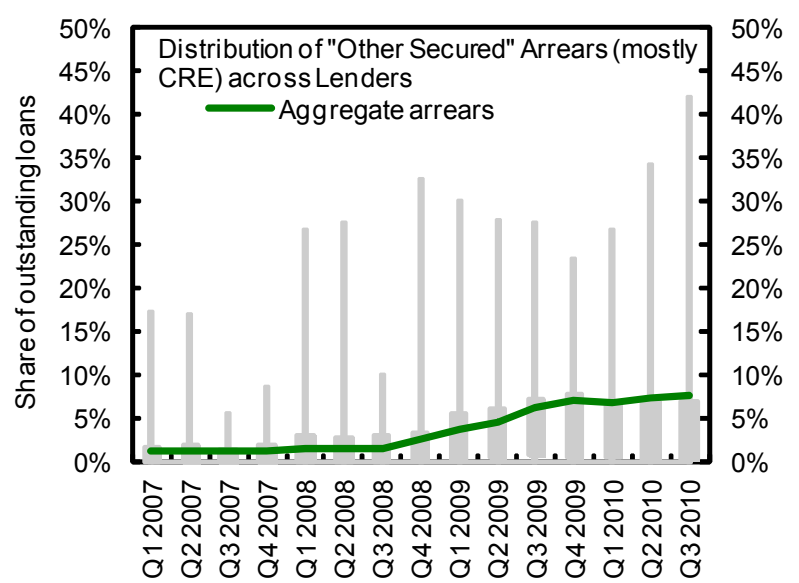

Sources: BoE; Bloomberg; Council of Mortgage Lenders; FSA, Prudential Risk Outlook; Haver Analytics; Land Registry; Office of National Statistics; and IMF staff estimates.

1/Sample includes Barclays, HSBC, LBG, Nationwide, RBS, SCB and Santander U.K. 


\section{Table 6. United Kingdom: Selected Economic Indicators}

\begin{tabular}{|c|c|c|c|c|c|c|}
\hline & 2007 & 2008 & 2009 & 2010 & $\begin{array}{r}2011 \\
\text { Proj. } \\
\end{array}$ & $\begin{array}{r}2012 \\
\text { Proj. }\end{array}$ \\
\hline \multicolumn{7}{|l|}{ Real Economy (change in percent) } \\
\hline Real GDP & 2.7 & -0.1 & -4.9 & 1.4 & 1.5 & 2.3 \\
\hline Domestic demand & 3.1 & -0.7 & -5.5 & 2.7 & -0.1 & 1.4 \\
\hline Private final domestic demand & 3.3 & -1.4 & -6.5 & 1.3 & 0.0 & 2.5 \\
\hline $\mathrm{CPI}$, end period & 2.1 & 3.1 & 2.9 & 3.7 & 4.5 & 2.2 \\
\hline Unemployment rate (in percent) $1 /$ & 5.4 & 5.6 & 7.5 & 7.9 & 7.7 & 7.6 \\
\hline Gross national saving (percent of GDP) & 15.6 & 15.0 & 11.8 & 11.8 & 11.5 & 12.5 \\
\hline Gross domestic investment (percent of GDP) & 18.2 & 16.6 & 13.5 & 15.0 & 14.0 & 14.5 \\
\hline \multicolumn{7}{|l|}{ Public Finance (fiscal year, percent of GDP) $2 /$} \\
\hline General government balance & -2.7 & -6.7 & -11.3 & -9.8 & -7.9 & -6.3 \\
\hline Public sector balance & -2.4 & -6.7 & -11.1 & -9.7 & -8.0 & -6.4 \\
\hline Cyclically adjusted balance (staff estimates) & -3.1 & -6.7 & -9.1 & -7.7 & -6.2 & -4.7 \\
\hline General government gross debt (excl. temp. effects of FS interventions) & 43.1 & 55.4 & 71.5 & 76.8 & 81.5 & 84.2 \\
\hline Public sector net debt (excl. temp. effects of FS interventions) & 36.6 & 43.3 & 52.8 & 59.8 & 65.7 & 69.3 \\
\hline FX-denominated public debt (percent of gross debt) & 0.2 & 0.0 & 0.0 & 0.0 & $\ldots$ & $\ldots$ \\
\hline \multicolumn{7}{|l|}{ Money and Credit (end-period, 12-month percent change) 3/ } \\
\hline M4 & 12.8 & 15.5 & 6.7 & -1.4 & -0.9 & $\ldots$ \\
\hline Net lending to private sector & 10.8 & 4.9 & 0.6 & -0.4 & 0.1 & $\ldots$ \\
\hline \multicolumn{7}{|l|}{ Interest rates (percent; year average) $3 /$} \\
\hline Three-month interbank rate & 6.0 & 5.8 & 1.2 & 0.7 & 0.8 & $\ldots$ \\
\hline Ten-year government bond yield & 5.0 & 4.7 & 3.6 & 3.6 & 3.8 & $\ldots$ \\
\hline \multicolumn{7}{|l|}{ Balance of Payments (percent of GDP) } \\
\hline Current account balance & -2.6 & -1.6 & -1.7 & -3.2 & -2.6 & -1.9 \\
\hline Trade balance & -3.1 & -2.6 & -2.1 & -3.4 & -2.0 & -1.3 \\
\hline Net exports of oil & -0.3 & -0.4 & -0.2 & -0.3 & -0.4 & -0.4 \\
\hline Exports of goods and services (volume change in percent) & -2.6 & 1.0 & -10.1 & 5.2 & 7.5 & 5.5 \\
\hline Imports of goods and services (volume change in percent) & -0.8 & -1.2 & -11.9 & 8.8 & 1.6 & 2.4 \\
\hline Terms of trade (percent change) & 1.4 & 0.0 & -0.9 & -0.2 & -1.1 & -0.6 \\
\hline FDI net & -4.4 & -2.6 & 1.2 & -0.7 & $\ldots$ & $\ldots$ \\
\hline Reserves (end of period, billions of US dollars) $4 /$ & 57.9 & 53.9 & 66.4 & 78.8 & 85.5 & $\ldots$ \\
\hline \multicolumn{7}{|l|}{ Fund Position (as of April 30, 2011) } \\
\hline Holdings of currency (in percent of quota) & & & & & & 69.1 \\
\hline Holdings of SDRs (in percent of allocation) & & & & & & 91.8 \\
\hline Quota (in millions of SDRs) & & & & & & 738.5 \\
\hline \multicolumn{7}{|l|}{ Exchange Rates } \\
\hline Exchange rate regime & & & & & \multicolumn{2}{|c|}{ Floating } \\
\hline Bilateral rate (June 3,2011 ) & & & & & US\$1 $=$ & .6092 \\
\hline Nominal effective rate $(2005=100) 3 / 5 /$ & 103.3 & 90.6 & 80.2 & 79.9 & 79.6 & $\ldots$ \\
\hline Real effective rate $(2005=100) 4 / 5 / 6 /$ & 105.2 & 92.1 & 80.8 & 83.6 & 85.1 & $\ldots$ \\
\hline
\end{tabular}

Sources: ONS; HMT; BoE; International Financial Statistics; INS; World Development Indicators; and IMF staff estimates and projections.

1/ ILO unemployment; based on Labor Force Survey data.

2/ The fiscal year begins in April. Debt stock data refers to the end of the fiscal year using centered-GDP as a denominator.

3/ 2011: Actual data through April.

4/ 2011: Actual data through March.

5/ Average. An increase denotes an appreciation.

6/ Based on relative consumer prices. 
- $\quad$ The banking system, in aggregate, has adequate liquidity buffers to withstand short-lived stresses, but remains vulnerable to sustained disruptions in funding markets. The overall liquidity shortfall remains contained even in a very severe 30-day stress test. However, sustained disruptions to wholesale funding markets, coupled with persistent declines in asset values could expose vulnerabilities. Funding sources are not sufficiently stable (see discussion on banks' Net Stable Funding Ratio below) and banks, including the major ones, have mismatched assets and liabilities at six-month maturities and longer. The substantial funding needs and the interconnectedness of the U.K. banks to the global financial system amplify the risks. The new discount window facility and pre-positioning of collateral aimed at facilitating quick use of the facility are important in managing such extreme stress events.

20. The FSA's stress tests of the insurance sector indicate resilience, but the low interest rate environment could create adverse incentives. Risk weightings under Solvency II may encourage insurers to allocate their portfolios as insurance companies seek to meet nominal return objectives and offset competition in their underwriting businesses. Supervisors need to remain vigilant regarding the quality of the investment portfolio and, if necessary, apply Pillar II requirements under Solvency II.

\section{Banking stress test analysis}

21. Stress tests were conducted for the seven major U.K. banks to assess solvency risk under a baseline and three adverse scenarios. These banks account for 71 percent of the assets in the system ( 80 percent of loans) and 90 percent of retail deposits. The stress-test horizon is from 2011-2015 using end-2010 financial data. The baseline projections are consistent with the IMF's World Economic Outlook, while the adverse scenarios comprise: (i) a "double-dip" recession scenario of one standard deviation of real GDP growth from the baseline growth trend over the first two years of a five-year horizon with positive adjustment dynamics during the subsequent three years ("DD mild"); (ii) a double-dip recession scenario of two standard deviations of the same ("DD severe"); and (iii) a "prolonged slow growth" scenario with a cumulative negative deviation of over 7 percentage points from baseline growth, or an average annual growth rate of almost 0.9 percent over five years ("SG"). Related key macro and financial variables are projected using the FSA's macro models (Figure 8 and Appendix III).

\section{Bottom-up (BU) solvency stress tests represent the core element of the analysis and} are cross-validated by top-down (TD) tests. Prescriptive assumptions covering areas such as risk, behavioral adjustments, and regulatory changes are also applied as consistently as possible across the three approaches (Appendix IV). The results are necessarily subject to wide confidence bands and can be summarized as follows:

\footnotetext{
${ }^{5}$ Based on the volatility of the two-year growth rate over 30 years as calculated by the FSA.
} 
- $\quad$ BU results show that banks have robust capital buffers that could absorb losses from severe stresses. The distribution of Core Tier 1 ratios for individual banks remain over the regulatory minima at any time over the 2011-15 period, per the Basel III schedule (Figure 9). The weighted-average capital ratios comfortably exceed the regulatory minima; and the average leverage ratio remains over 4.5 percent. Capital buffers comfortably absorb credit losses arising from a sharp recession, with retail-focused banks hardest hit. Buffers are also sufficient to absorb market-risk charges due to exchange rate shocks to major currencies and higher risk weights on securitization and counterparty risk exposures under revised regulatory standards. Exposures to sovereign and bank debt do not seem to represent a major source of risk; ${ }^{6}$ aggregate losses of around 0.2 percent of GDP ( $£ 3.5$ billion) over the five-year horizon are estimated for the former, which represents the greater risk, unless stresses lead to severe disruptions in wholesale funding markets (see below).

- $\quad$ The authorities' TD tests using the Bank of England's Risk Assessment Model for Systemic Institutions (RAMSI) show similar broad trends under each scenario. ${ }^{7}$ In contrast to the BU findings, however, shocks to sovereign and bank debt appear to have greater effect on capital adequacy, of up to 0.9 percentage points on core Tier 1 capital, which remains well above the relevant hurdle rates nonetheless (Figure 10).

- $\quad$ The FSAP's TD approach, the Systemic Contingent Claims Analysis (Systemic CCA), is applied to estimate systemic solvency risk. ${ }^{8}$ The estimated joint potential capital shortfall suggests that markets are broadly comfortable that the banks have sufficient buffers to withstand the prescribed shocks (Figure 11 and Table 7). Under (median) baseline conditions, the impact on market-implied capital from the realization of declining profitability amounts to an average 0.03 percent of 2010 GDP ( $£ 0.4$ billion) between 2011-15. Under the severe double-dip recession scenario, market-implied capital levels could decline by up to an average 0.12 percent of 2010 GDP ( $£ 1.8$ billion) over the next five years. If multiple banks experience a dramatic escalation of losses under a "tail of the tail risk" scenario (0.1 percent probability event), current market-implied capital levels over the five-year stress test horizon could potentially be eroded by between 2.7-3.4 percent of 2010 GDP ( $£ 37-£ 50$ billion) on average, albeit still well below the peaks seen

\footnotetext{
${ }^{6}$ Estimated losses from shocks to sovereign and bank debt holdings include the trading book, available-for-sale and held-to-maturity.

${ }^{7}$ RAMSI incorporates detailed information on each bank's balance sheet and profit-and-loss account, and uses a set of interconnected modules to analyze banks' dynamic response to a change in macro-financial conditions. Banks are assumed to increase capital through retained earnings until they achieve challenging core Tier 1 capital ratio targets that are set using Basel III definitions and then translated back into Basel II terms.

${ }^{8}$ The Systemic CCA framework combines equity market and balance sheet information to infer underlying asset dynamics and expected losses in a multivariate set up (see Gray, D. and A. Jobst, 2010, "New Directions in Financial Sector and Sovereign Risk Management," Journal of Investment Management, Vol. 8, No. 1).
} 
during the Lehman crisis (Figure 11 and Table 7). Under this scenario, an average capital shortfall of between 1.3-1.6 percent of 2010 GDP could materialize relative to the Basel III Tier 1 hurdle rates (and 1.6-1.8 percent of 2010 GDP relative to the FSA Interim Capital Regime Tier 1 requirements).

23. An important caveat to the haircuts applied to banks' debt holdings of all non-AAA rated sovereigns and banks in those countries is that their severity and dynamics are informed by the forward term structure of 5-year sovereign credit default swap (CDS) spreads as at end-2010. Since then, the sovereign CDS spreads for select debtor countries of U.K. banks have increased commensurately with the rising risks to the economic outlook (Figure 12), which are not reflected in the haircuts, given the cut-off point for the stress tests. This means that U.K. banks could be affected by additional losses - well beyond the prescribed haircuts - in the event that shocks lead to extreme stresses in the private sector in those countries or in core European banks to which they have large exposures.

24. The liquidity tests assess the short-term resilience of the system to sudden, sizeable withdrawals of funding. The sample includes 16 institutions - the 7 major banks, selected foreign investment banks and building societies. Two implied cash-flow tests - based on the Quantitative Impact Study (QIS-6) assumptions - simulate a gradual outflow of funding over five consecutive days and over a 30-day time horizon in keeping with a reverse stress test rationale (Appendix V). The FSAP team's interpretation of the proposed Basel III liquidity risk measures are also applied - the Liquidity Coverage Ratio (LCR) measures the sufficiency of the stock of high quality liquid assets to meet up to 30 days of institution-specific and systemic stress and the Net Stable Funding Ratio (NSFR) provides insights into the quality of liquid assets and the maturity profile and stability of funding in the system. We refer to these as quasi-measures, given that they are not yet definite. The findings are summarized below (Tables 8 and 9):

- $\quad$ Banks have sufficient holdings of highly-liquid assets to offset outflows during short-lived (five days) moderately severe cash-flow shocks, assuming that deposits remain stable. In the case of deposit outflows, the aggregate shortfall would equal 0.03 percent of assets for the sample of 16 banks. The results highlight the importance of retail deposits as a key source of funding for the banking system, while intra-group funding does not appear to play an important role for the foreign subsidiaries in the sample.

- $\quad$ The overall liquidity shortfall remains largely contained even when deposit outflows and the run-off of liabilities are doubled in a very severe 30-day scenario. The FSAP's assumed cumulative outflows of more than 40 percent of both wholesale and deposit funding under this test exceed current supervisory requirements and are greater than those experienced by Northern Rock during the crisis. Given the severity of the underlying assumptions, this test would, in effect, help identify institutions" "point of failure" in the nature of a reverse stress test. The aggregate shortfall amounts to about 6 percent of assets for 14 out of the sample of 16 banks, with significant impact concentrated in a few institutions. 
- $\quad$ Sources of funding in the banking system are not sufficiently stable. The quasi-NSFR test shows that banks accounting for more than 95 percent of liquid assets do not have sufficient stable funding (i.e., NSFR ratio of less than unity). In the 6-12 months maturity bucket, assets that are mismatched amount to about 70 percent of the total assets of all banks in the sample, and the proportion goes up to around 90 percent in the 12-plus months maturity bucket. For some banks, this vulnerability would be amplified by their reliance on wholesale funding.

\section{Insurance stress test analysis}

\section{The quality of the insurance stress testing carried out by the FSA is high and} consistent with the sophistication of the market. While the Individual Capital Assessment (ICA) regime has required stress testing at an individual firm level since its introduction in 2005, industry-wide stress testing only began in 2008 when the FSA identified the need to gain a better understanding of the resilience of the market in the wake of the crisis. Since then, the FSA has carried out, at least on a yearly basis, different types of stress testing, including firm-specific reverse stress tests that capture the extreme situations leading to the failure of an insurer.

\section{Insurance stress tests undertaken by the FSA in 2010 targeted the six largest} insurance groups based on end-December 2009 balance sheets. The exercise, part of the recently established Core Prudential Program Insurance (CPPi), consisted of a series of stress scenarios, including extreme tail-risk scenarios, to test regulatory surplus capital and group liquidity. The firms passed all severe tests at group and solo levels. For life insurers, credit risk remains the largest driver of risks to solvency; market and property risks are also significant. The results led to a series of supervisory recommendations, including changes to the investment portfolios and strengthening of interest rate exposure management. Based on the results of the extreme tests, a series of actions were imposed on firms to further improve their resilience beyond regulatory requirements. 
Figure 7. Overview of the U.K. FSAP Update Stress Testing Exercise

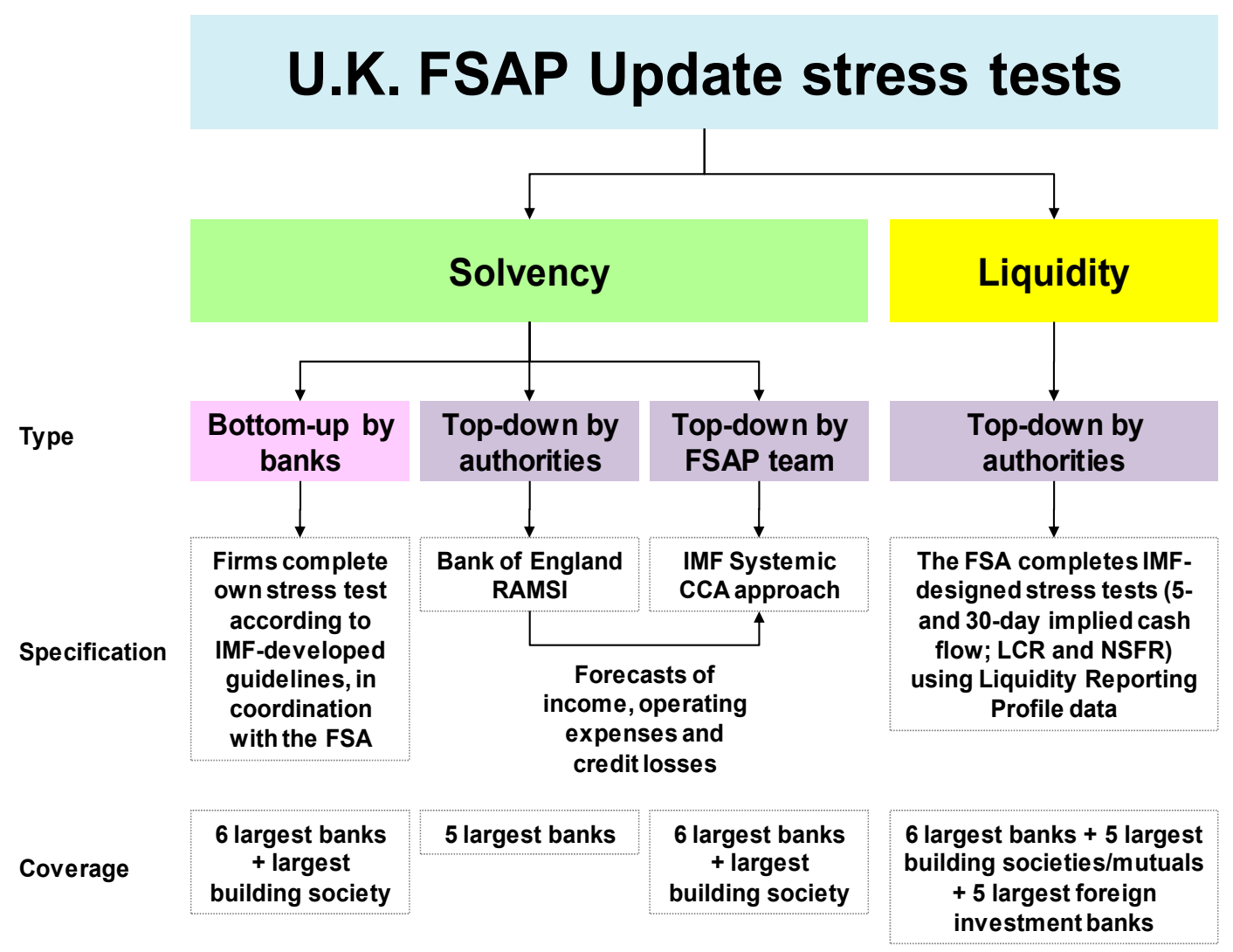


Figure 8. Overview of the U.K. FSAP Update Stress Test Scenarios
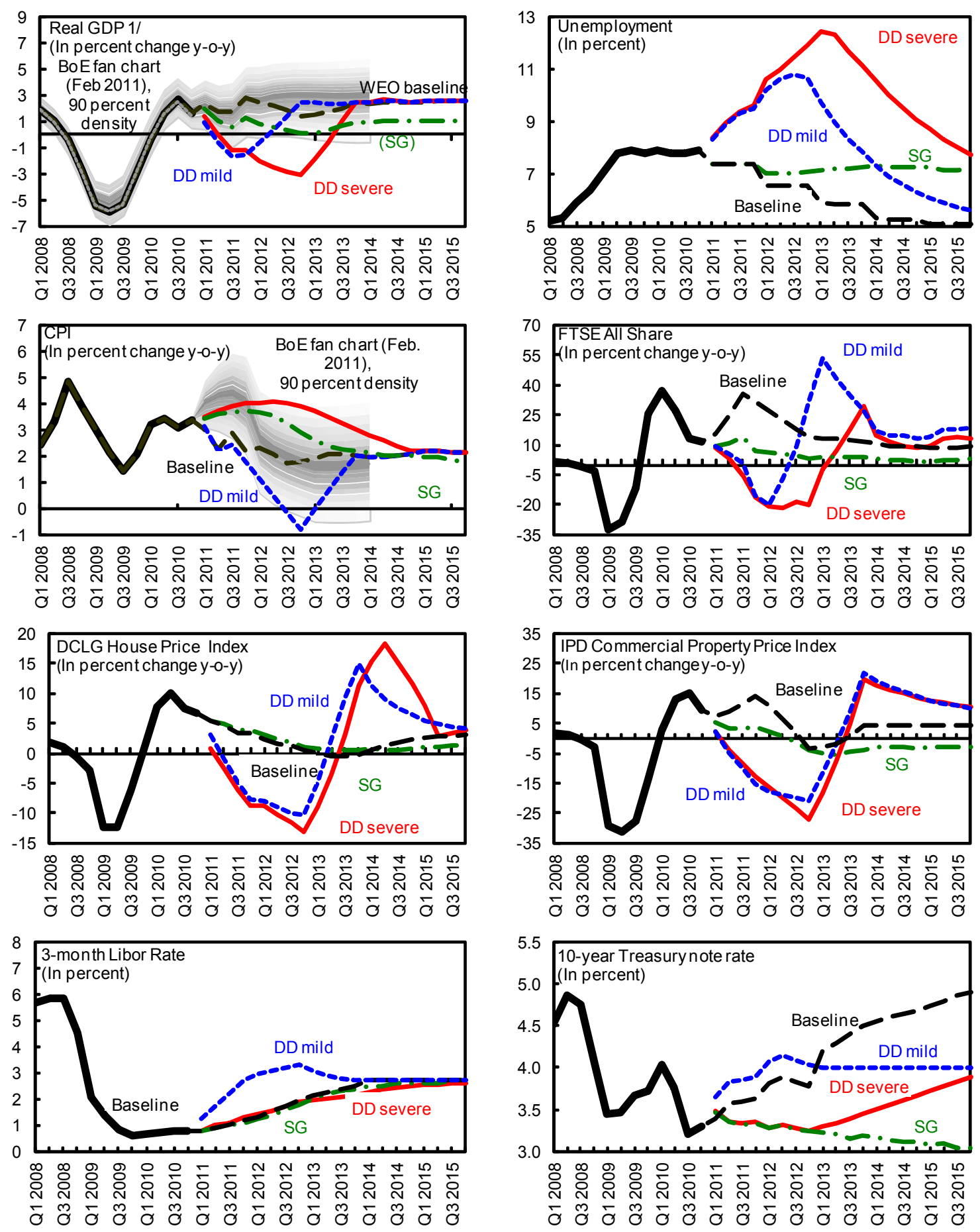

\footnotetext{
--- IMF mild double dip recession (DD mild) = European Banking Authority 2011 adverse scenario.

- IMF severe double dip recession (DD severe) = FSA 2011 anchor scenario.

--- IMF prolonged slow growth scenario (SG).
}

Sources: BoE; FSA; and IMF staff calculations. 
Figure 9. Distribution of Core Tier 1 Capital Ratios from the U.K. FSAP Update Bottom-Up Stress Tests, 2011-15

(In percent)
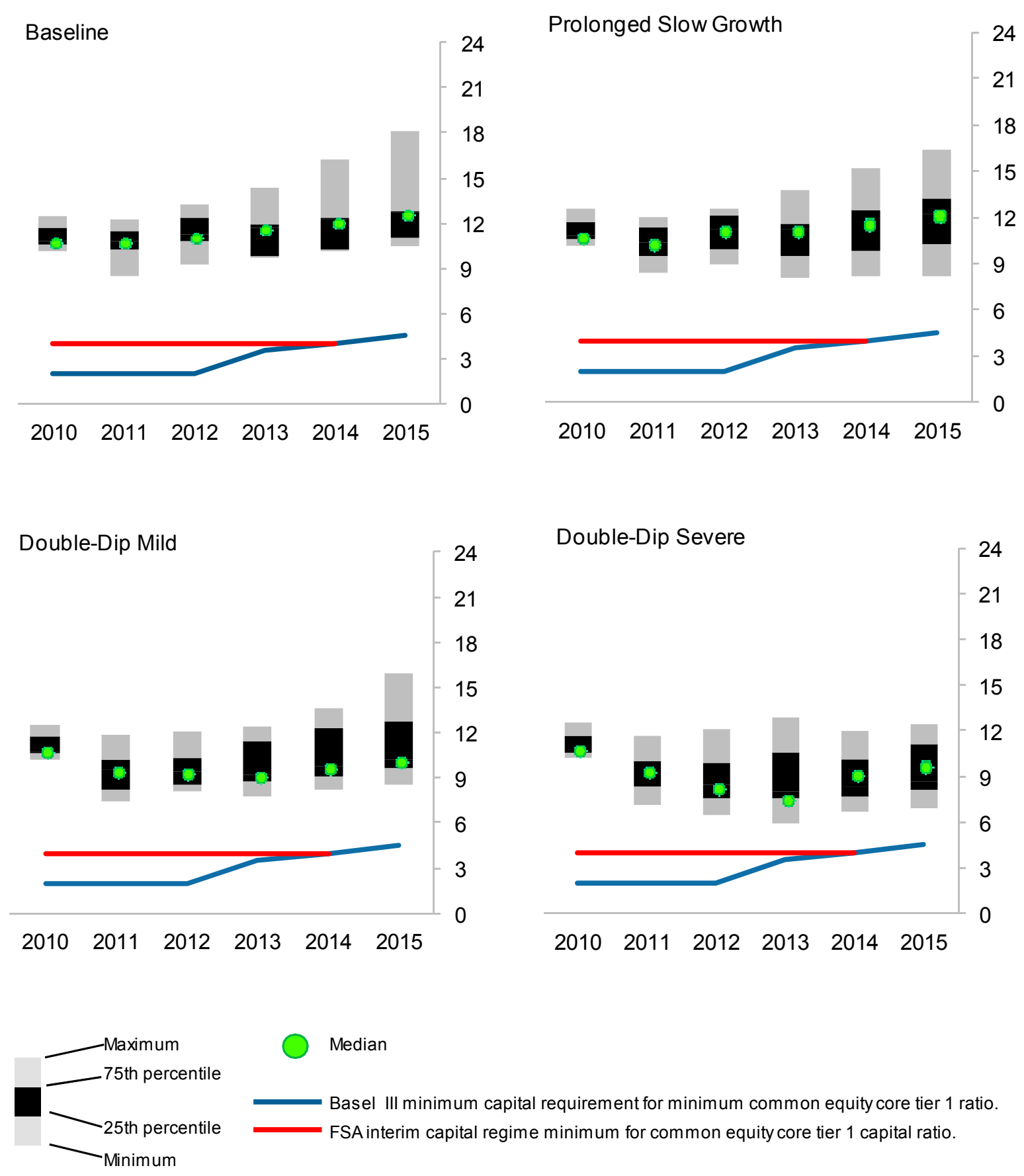

Sources: FSA; major U.K. banks; and IMF staff calculations. 
Figure 10. Weighted-Average Core Tier 1 Capital Ratios from the U.K. FSAP Update Bottom-Up and BoE RAMSI Top-Down Stress Tests, 2011-15

(In percentage points)

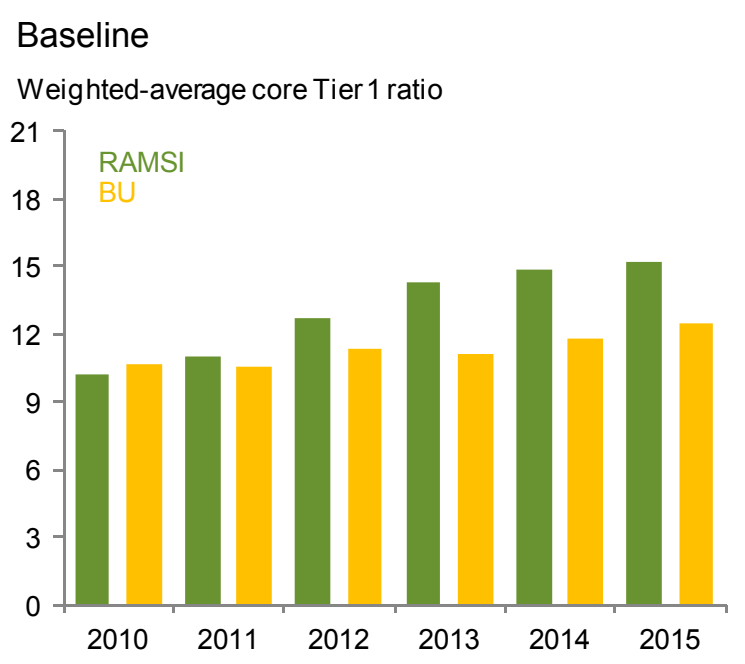

Double-Dip Mild

Change in weighted-average core Tier 1 ratio from baseline

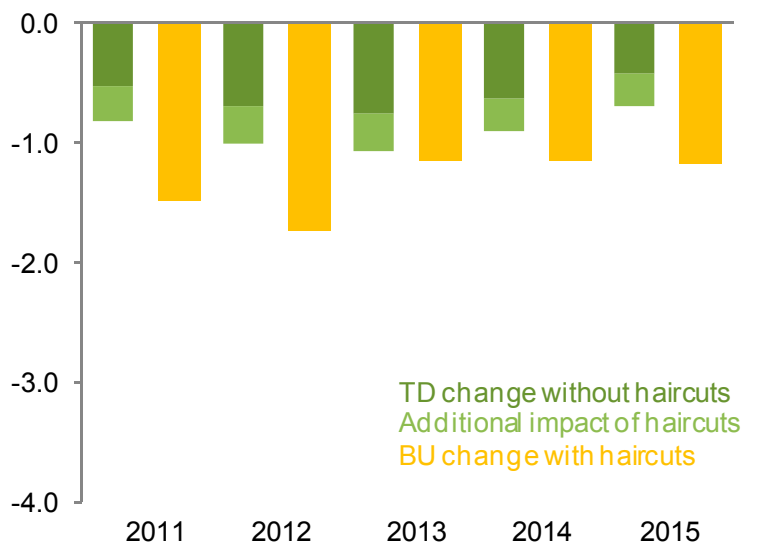

Prolonged Slow Growth

Change in aweighted-verage core Tier 1 ratio from baseline

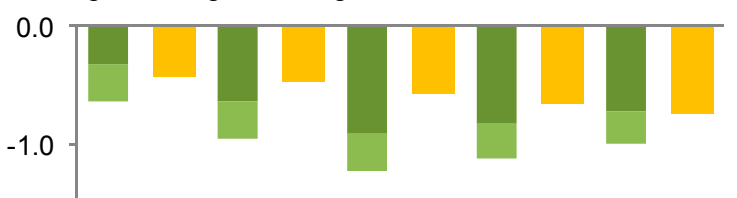

$-2.0$

$-3.0$

TD change without haircuts Additional impact of haircuts

BU change with haircuts

$-4.0$

2011

2012

$2013 \quad 2014$

2015

\section{Double-Dip Severe}

Change in weighted-average core Tier 1 ratio from baseline

0.0

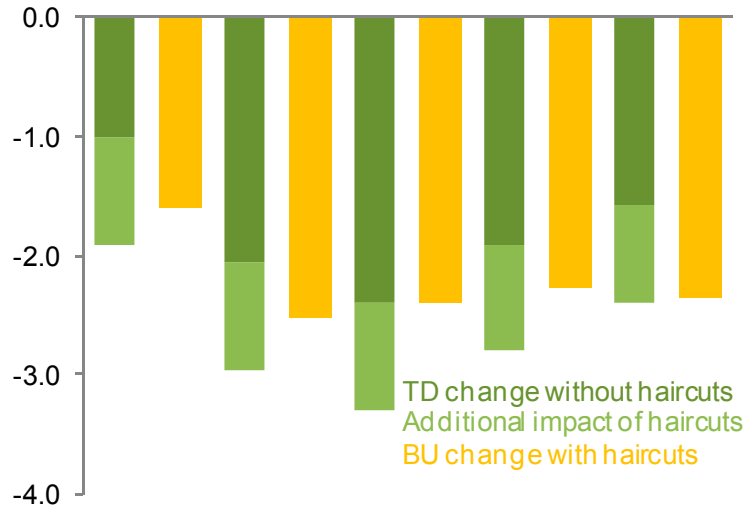

$-4.0$

$\begin{array}{lllll}2011 & 2012 & 2013 & 2014 & 2015\end{array}$

Sources: BoE; FSA; individual banks; and IMF staff calculations.

Note: The definitions of capital are as follows: For the BU exercise, the starting point is in line with FSA definitions as laid out in the FSA Handbook and the definition of capital in the FSA Interim Capital Regime; for the RAMSI, the Basel II-consistent definition of capital is used. 
Figure 11. Systemic CCA Estimates of the Market-Implied Joint Capital Losses from the U.K. FSAP Update Top-Down Stress Tests, Historical and Expected (with IMF Satellite Model)

(In billions of pound sterling)
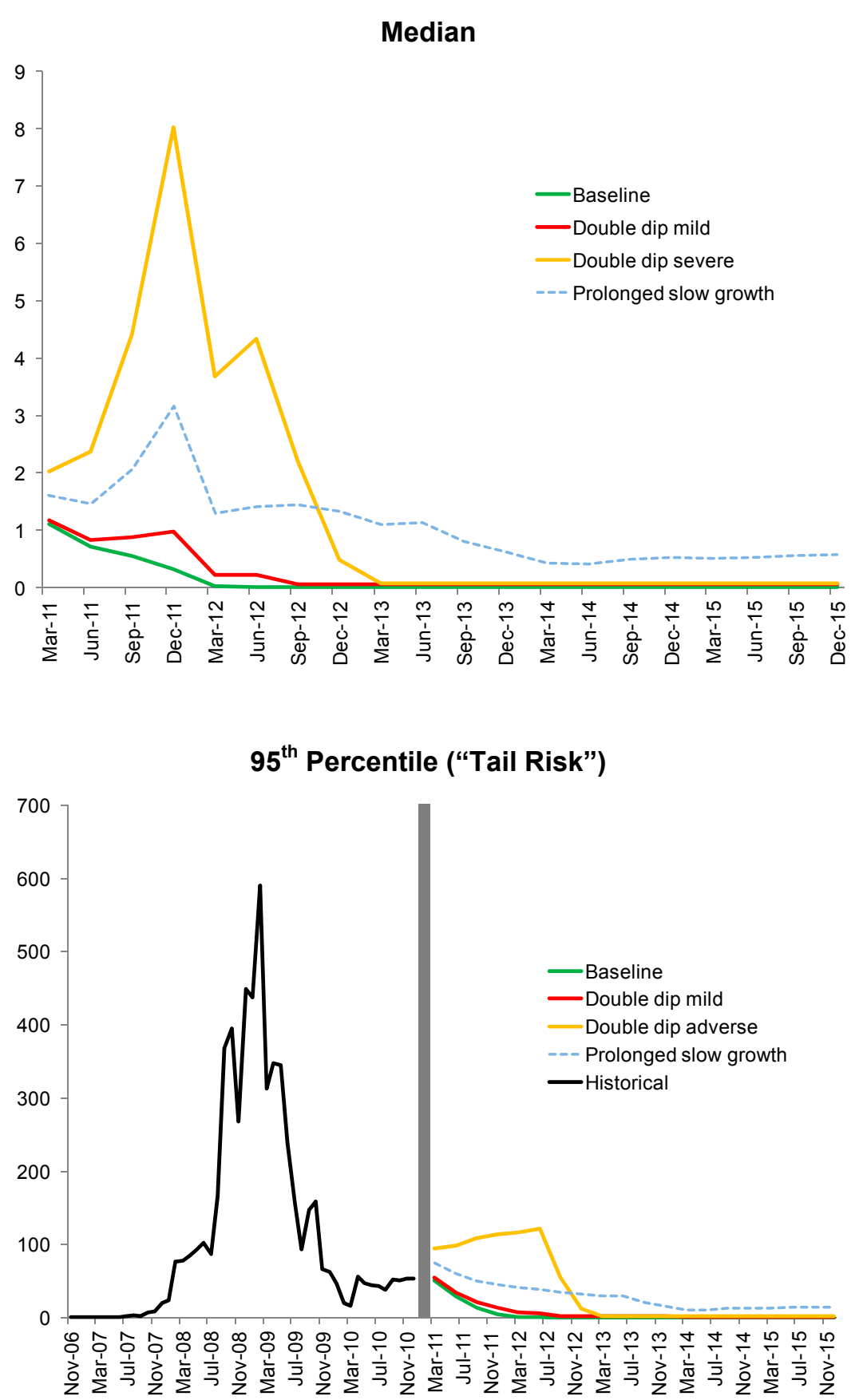

Source: IMF staff calculations. 


\section{Table 7. Systemic CCA Estimates of the Market-Implied Joint Expected Capital Loss and Resulting Shortfall from the U.K. FSAP Update Top-Down Stress Tests, 2011-15}

(Average over time period, in billions of pound sterling unless stated otherwise)

\begin{tabular}{|c|c|c|c|c|c|c|c|c|c|c|c|c|c|c|c|c|}
\hline \multirow{4}{*}{ Forecast Period } & \multicolumn{8}{|c|}{ IMF Satellite Model 1/ } & \multicolumn{8}{|c|}{ Structural Model 21} \\
\hline & \multirow{3}{*}{$\begin{array}{c}\text { Without } \\
\text { Baseline }\end{array}$} & \multirow{2}{*}{\multicolumn{3}{|c|}{$\begin{array}{c}\text { vereign and Bank Debt Haircuts } \\
\text { Adverse Scenarios }\end{array}$}} & \multirow{3}{*}{$\begin{array}{l}\text { With S } \\
\text { Baseline }\end{array}$} & ereign anc & Bank Debt & aircuts & Without & \multirow{2}{*}{\multicolumn{3}{|c|}{$\begin{array}{c}\text { vereign and Bank Debt Haircuts } \\
\text { Adverse Scenarios }\end{array}$}} & \multirow{3}{*}{$\frac{\text { Wheth }}{\text { Baseline }}$} & \multirow{2}{*}{\multicolumn{3}{|c|}{$\begin{array}{c}\text { Peign and Bank Debt Haircuts } \\
\text { Adverse Scenarios }\end{array}$}} \\
\hline & & & & & & \multicolumn{3}{|c|}{$\begin{array}{l}\text { Adverse Scenarios } \\
\end{array}$} & \multirow{2}{*}{ Baseline } & & & & & & & \\
\hline & & DD Mild & DD Severe & SG & & DD Mild & DD Severe & SG & & DD Mild & DD Severe & $S G$ & & DD Mild & & SG \\
\hline & \multicolumn{16}{|c|}{ Market-Implied Joint Potential Capital Loss } \\
\hline & \multicolumn{16}{|c|}{ Median } \\
\hline $2011-15$ & 0.13 & 0.20 & 1.35 & 0.67 & 0.14 & 0.26 & 1.43 & 1.07 & 0.43 & 0.62 & 0.98 & 0.71 & 0.48 & 1.04 & 1.77 & 0.98 \\
\hline In percent of GDP & 0.01 & 0.01 & 0.09 & 0.05 & 0.01 & 0.02 & 0.10 & 0.07 & 0.03 & 0.04 & 0.07 & 0.05 & 0.03 & 0.07 & 0.12 & 0.07 \\
\hline 2011 & 0.66 & 0.91 & 4.13 & 1.65 & 0.67 & 0.97 & 4.21 & 2.08 & 0.90 & 1.35 & 1.94 & 1.20 & 1.00 & 1.92 & 2.96 & 1.53 \\
\hline 2012 & 0.00 & 0.08 & 2.60 & 0.96 & 0.02 & 0.15 & 2.69 & 1.37 & 0.38 & 0.63 & 1.41 & 0.65 & 0.43 & 1.12 & 2.40 & 0.93 \\
\hline 2013 & 0.00 & 0.00 & 0.00 & 0.52 & 0.01 & 0.06 & 0.08 & 0.92 & 0.27 & 0.37 & 0.61 & 0.50 & 0.30 & 0.74 & 1.33 & 0.73 \\
\hline \multirow{3}{*}{2015} & 0.00 & 0.00 & 0.00 & 0.08 & 0.01 & 0.06 & 0.08 & 0.46 & 0.30 & 0.42 & 0.54 & 0.61 & 0.33 & 0.80 & 1.20 & 0.86 \\
\hline & 0.00 & 0.00 & 0.00 & 0.16 & 0.01 & 0.06 & 0.08 & 0.54 & 0.30 & 0.34 & 0.41 & 0.59 & 0.33 & 0.64 & 0.94 & 0.83 \\
\hline & \multicolumn{16}{|c|}{95 Percent (Tail Risk) 3/ } \\
\hline 2011-15 & 4.91 & 6.42 & 35.08 & 18.55 & 5.18 & 8.01 & 37.21 & 29.02 & 12.29 & 17.84 & 28.04 & 19.99 & 13.71 & 29.61 & 49.86 & 27.32 \\
\hline In percent of GDP & 0.34 & 0.44 & 2.41 & 1.28 & 0.36 & 0.55 & 2.56 & 2.00 & 0.85 & 1.23 & 1.93 & 1.38 & 0.94 & 2.04 & 3.43 & 1.88 \\
\hline 2011 & 24.39 & 29.58 & 101.46 & 46.88 & 24.69 & 31.16 & 103.60 & 57.80 & 28.56 & 42.68 & 61.46 & 37.97 & 31.71 & 60.83 & 93.68 & 48.42 \\
\hline 2012 & 0.13 & 2.53 & 73.94 & 26.22 & 0.43 & 4.18 & 76.15 & 37.07 & 10.31 & 17.02 & 38.30 & 17.65 & 11.76 & 30.56 & 65.12 & 25.17 \\
\hline 2013 & 0.00 & 0.00 & 0.00 & 13.61 & 0.27 & 1.63 & 2.19 & 24.10 & 6.97 & 9.73 & 15.88 & 13.05 & 7.85 & 19.42 & 34.93 & 19.04 \\
\hline 2014 & 0.00 & 0.00 & 0.00 & 1.95 & 0.26 & 1.57 & 2.10 & 12.04 & 7.85 & 10.97 & 14.00 & 15.90 & 8.68 & 20.67 & 31.21 & 22.38 \\
\hline \multirow[t]{3}{*}{2015} & 0.00 & 0.00 & 0.00 & 4.09 & 0.25 & 1.52 & 2.01 & 14.11 & 7.75 & 8.82 & 10.57 & 15.40 & 8.55 & 16.58 & 24.37 & 21.60 \\
\hline & \multicolumn{16}{|c|}{ Market-Implied Joint Potential Capital Shortfall } \\
\hline & \multicolumn{16}{|c|}{$\underline{\text { Median }}$} \\
\hline $2011-15$ & 0.00 & 0.00 & 0.00 & 0.00 & 0.00 & 0.00 & 0.00 & 0.00 & 0.00 & 0.00 & 0.00 & 0.00 & 0.00 & 0.00 & 0.00 & 0.00 \\
\hline In percent of GDP & 0.00 & 0.00 & 0.00 & 0.00 & 0.00 & 0.00 & 0.00 & 0.00 & 0.00 & 0.00 & 0.00 & 0.00 & 0.00 & 0.00 & 0.00 & 0.00 \\
\hline 2011 & 0.00 & 0.00 & 0.00 & 0.00 & 0.00 & 0.00 & 0.00 & 0.00 & 0.00 & 0.00 & 0.00 & 0.00 & 0.00 & 0.00 & 0.00 & 0.00 \\
\hline 2012 & 0.00 & 0.00 & 0.00 & 0.00 & 0.00 & 0.00 & 0.00 & 0.00 & 0.00 & 0.00 & 0.00 & 0.00 & 0.00 & 0.00 & 0.00 & 0.00 \\
\hline 2013 & 0.00 & 0.00 & 0.00 & 0.00 & 0.00 & 0.00 & 0.00 & 0.00 & 0.00 & 0.00 & 0.00 & 0.00 & 0.00 & 0.00 & 0.00 & 0.00 \\
\hline 2014 & 0.00 & 0.00 & 0.00 & 0.00 & 0.00 & 0.00 & 0.00 & 0.00 & 0.00 & 0.00 & 0.00 & 0.00 & 0.00 & 0.00 & 0.00 & 0.00 \\
\hline \multirow[t]{2}{*}{2015} & 0.00 & 0.00 & 0.00 & 0.00 & 0.00 & 0.00 & 0.00 & 0.00 & 0.00 & 0.00 & 0.00 & 0.00 & 0.00 & 0.00 & 0.00 & 0.00 \\
\hline & \multicolumn{16}{|c|}{$\underline{95 \text { Percent (Tail Risk) } 3 /}$} \\
\hline 2011-15 & 0.00 & 0.00 & 22.61 & 3.30 & 0.00 & 0.00 & 23.48 & 6.28 & 0.00 & 2.08 & 7.48 & 1.52 & 0.00 & 5.71 & 19.40 & 3.61 \\
\hline In percent of GDP & 0.00 & 0.00 & 1.56 & 0.23 & 0.00 & 0.00 & 1.62 & 0.43 & 0.00 & 0.14 & 0.51 & 0.10 & 0.00 & 0.39 & 1.33 & 0.25 \\
\hline 2011 & 0.00 & 0.00 & 71.20 & 16.49 & 0.00 & 0.00 & 73.34 & 27.41 & 0.0 & 10.40 & 31.19 & 7.58 & 0.00 & 28.55 & 63.42 & 18.03 \\
\hline 2012 & 0.00 & 0.00 & 41.84 & 0.00 & 0.00 & 0.00 & 44.05 & 3.98 & 0.00 & 0.00 & 6.20 & 0.00 & 0.00 & 0.00 & 33.02 & 0.00 \\
\hline 2013 & 0.00 & 0.00 & 0.00 & 0.00 & 0.00 & 0.00 & 0.00 & 0.00 & 0.00 & 0.00 & 0.00 & 0.00 & 0.00 & 0.00 & 0.54 & 0.00 \\
\hline 2014 & 0.00 & 0.00 & 0.00 & 0.00 & 0.00 & 0.00 & 0.00 & 0.00 & 0.00 & 0.00 & 0.00 & 0.00 & 0.00 & 0.00 & 0.00 & 0.00 \\
\hline 2015 & 0.00 & 0.00 & 0.00 & 0.00 & 0.00 & 0.00 & 0.00 & 0.00 & 0.00 & 0.00 & 0.00 & 0.00 & 0.00 & 0.00 & 0.00 & 0.00 \\
\hline
\end{tabular}

Source: IMF staff calculations.

Note: The estimations show the joint capital requirements for maintaining the market value of Tier 1 capital, with a gradual increase of the hurdle rate from 2013 onwards consistent with the Basel III proposal as at December 2010.

1/ The IMF satellite model uses a set of macroeconomic variables (short-term interest rates, longterm interest rates, real GDP growth, and unemployment) as well as income elements specific to each bank (operating profit, net interest income) to project expected losses generated by the CCA methodology.

2/ As an alternative, projected operating profit based on RAMSI model results is integrated in the CCA framework by adjusting implied bank assets, which increase expected losses via an option pricing approach. The treatment of losses from haircuts on holdings of sovereign and bank debt differs between both satellite model approaches. In the case of the former, these losses are calculated each year and added to the estimated overall expected losses. In contrast, for the alternative satellite model, losses from these debt holdings are subtracted from the RAMSI-model projected operating profit each quarter.

3/ The tail risk at the 95th percentile represents the average probability density beyond the 95th percentile as a threshold level. 
Figure 12. Selected EU Countries: CDS Spreads

(In basis points)

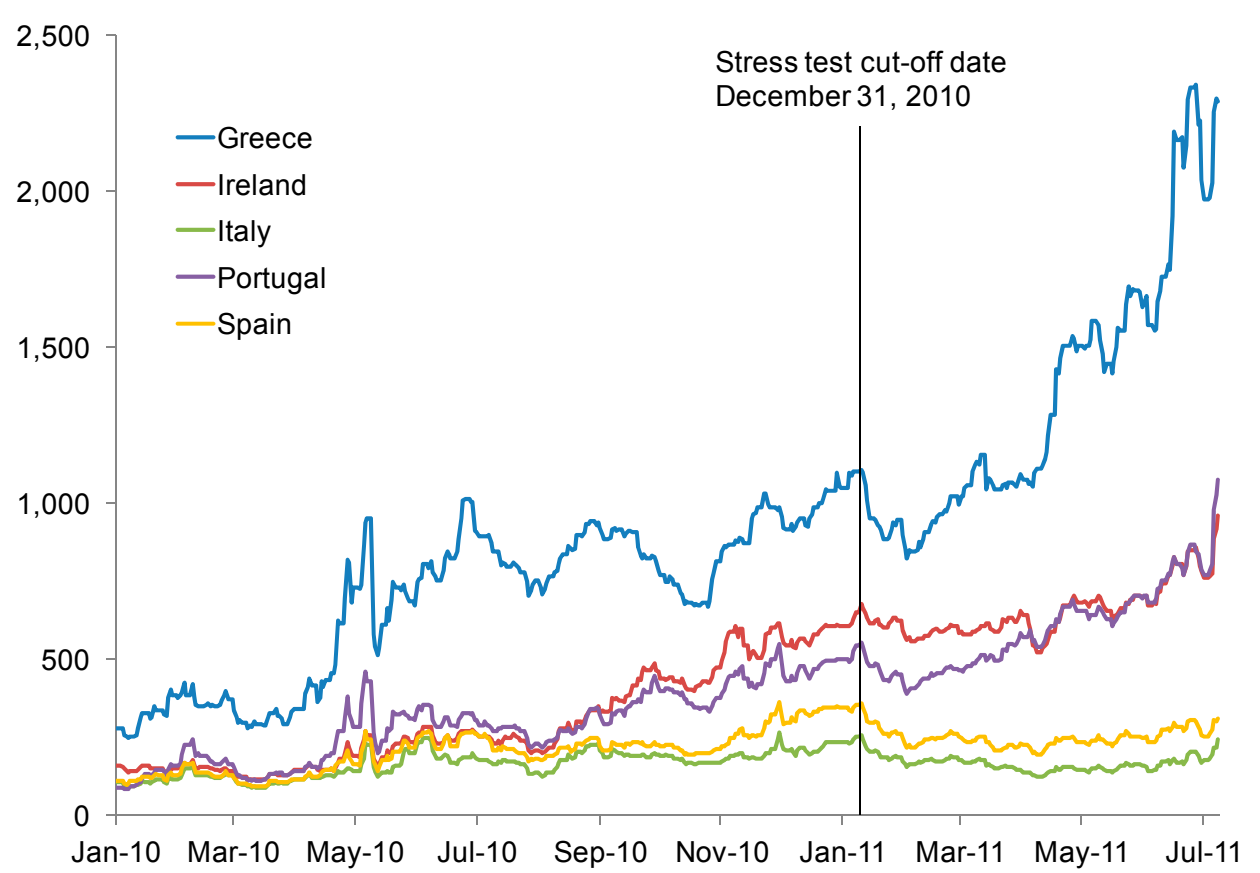

Source: Markit. 


\section{Table 8. U.K. FSAP Update Liquidity Stress Tests-5- and 30-Day Implied Cash Flow Analysis}

\begin{tabular}{|c|c|c|c|c|c|}
\hline & \multirow{2}{*}{$\begin{array}{l}\text { Number of } \\
\text { Banks below } \\
\text { Defined } \\
\text { Benchmark }\end{array}$} & \multicolumn{2}{|c|}{$\begin{array}{c}\text { Shortfall } \\
\text { (In percent of total sample assets } \\
\text { included in the liquidity tests) }\end{array}$} & \multirow{2}{*}{$\begin{array}{c}\text { Cumulative } \\
\text { Withdrawal of } \\
\text { Deposits } 1 / \\
\text { (In percent of total } \\
\text { deposits) }\end{array}$} & \multirow{2}{*}{$\begin{array}{l}\text { Cumulative Loss } \\
\text { of Wholesale } \\
\text { Funding } 1 / \\
\text { (In percent of total } \\
\text { wholesale funding) }\end{array}$} \\
\hline & & Total & $\begin{array}{l}\text { Average per Bank } \\
\text { in Shortfall }\end{array}$ & & \\
\hline & \multicolumn{5}{|c|}{ 5-Day Test } \\
\hline \multicolumn{6}{|l|}{ All firms (16) } \\
\hline Original assumptions & 1 & 0.03 & 0.03 & 18.0 & 25.5 \\
\hline Alternative 1: No withdrawal of retail deposits & 0 & 0.00 & 0.00 & 5.0 & 25.5 \\
\hline Alternative 2: Availability of intergroup funding & 1 & 0.03 & 0.03 & 18.0 & 25.5 \\
\hline \multicolumn{6}{|l|}{ Largest firms (7) } \\
\hline Original assumptions & 1 & 0.04 & 0.04 & 18.4 & 27.5 \\
\hline Alternative 1: No withdrawal of retail deposits & 0 & 0.00 & 0.00 & 4.9 & 27.5 \\
\hline Alternative 2: Availability of intergroup funding & 1 & 0.04 & 0.04 & 18.4 & 27.5 \\
\hline & \multicolumn{5}{|c|}{ 30-Day Test } \\
\hline \multicolumn{6}{|l|}{ All firms (16) } \\
\hline Original assumptions & 14 & 5.77 & 0.41 & 43.8 & 40.9 \\
\hline Alternative 1: No withdrawal of retail deposits & 4 & 0.41 & 0.10 & 15.2 & 40.9 \\
\hline Alternative 2: Availability of intergroup funding & 9 & 2.22 & 0.25 & 43.8 & 40.9 \\
\hline \multicolumn{6}{|l|}{ Largest firms (7) } \\
\hline Original assumptions & 7 & 6.64 & 0.95 & 44.6 & 41.5 \\
\hline Alternative 1: No withdrawal of retail deposits & 1 & 0.02 & 0.02 & 14.6 & 41.5 \\
\hline Alternative 2: Availability of intergroup funding & 5 & 2.81 & 0.56 & 44.6 & 41.5 \\
\hline
\end{tabular}

Sources: FSA; and IMF staff calculations.

1/ Cumulative outflows are weighted across different types of deposits and sources of wholesale funding, whose relative magnitude differs across sample banks. Note that the implied cash flow analysis applies outflow assumptions to aggregate values of funding maturities of up to one month irrespective of callability. The FSA does not complete tests that are directly comparable to these results. However, the survival day metric monitored by the FSA to assess vulnerabilities to wholesale funding is broadly similar to the 30 -day test. 


\section{Table 9. U.K. FSAP Update Liquidity Stress Tests-Quasi-Basel III and Maturity Mismatch Analysis}

(In percent of total sample assets included in the liquidity tests)

\begin{tabular}{|c|c|c|c|c|c|}
\hline \multirow[b]{3}{*}{ Ratio range } & \multicolumn{5}{|c|}{ Measure } \\
\hline & \multicolumn{5}{|c|}{ Quasi-Liquidity Coverage Ratio (LCR) } \\
\hline & $<0.25$ & $0.25-0.50$ & $0.50-0.75$ & $0.75-1.00$ & $>1.00$ \\
\hline & \multicolumn{5}{|c|}{ FSAP Assumptions } \\
\hline & - & - & - & - & 100.0 \\
\hline \multirow[t]{2}{*}{ Largest firms (7) } & - & - & - & - & 100.0 \\
\hline & \multicolumn{5}{|c|}{ FSA Assumptions } \\
\hline All firms (16) & - & 5.1 & 64.2 & 15.4 & 15.3 \\
\hline \multirow[t]{2}{*}{ Largest firms (7) } & - & - & 74.7 & 19.0 & 6.3 \\
\hline & \multicolumn{5}{|c|}{ Quasi-Net Stable Funding Ratio (NSFR) } \\
\hline \multirow[t]{2}{*}{ Ratio range } & $<0.25$ & $0.25-0.50$ & $0.50-0.75$ & $0.75-1.00$ & $>1.00$ \\
\hline & \multicolumn{5}{|c|}{ FSAP Assumptions } \\
\hline All firms (16) & 11.4 & 25.4 & 50.9 & 9.9 & 2.3 \\
\hline \multirow[t]{2}{*}{ Largest firms (7) } & - & 28.3 & 58.2 & 12.3 & 1.2 \\
\hline & \multicolumn{5}{|c|}{ FSA Assumptions } \\
\hline All firms (16) & - & 2.6 & - & 89.8 & 7.6 \\
\hline \multirow[t]{2}{*}{ Largest firms (7) } & - & - & - & 100.0 & - \\
\hline & \multicolumn{5}{|c|}{ Maturity Mismatch } \\
\hline Maturity tenor & $\begin{array}{l}\text { less than } 1 \\
\text { month }\end{array}$ & $\begin{array}{l}\text { within 1-3 } \\
\text { months }\end{array}$ & $\begin{array}{l}\text { within 3-6 } \\
\text { months }\end{array}$ & $\begin{array}{c}\text { between 6-12 } \\
\text { months }\end{array}$ & $\begin{array}{l}\text { after } 12 \\
\text { months }\end{array}$ \\
\hline All firms (16) & 11.6 & 29.1 & 22.3 & 68.9 & 89.2 \\
\hline Largest firms (7) & - & 23.9 & 16.8 & 70.5 & 92.7 \\
\hline
\end{tabular}

Sources: FSA; and IMF staff calculations.

$1 /$ The maturity mismatch of each bank is calculated as the difference of the value of assets and liabilities in each of six "maturity buckets" determined by their tenor and callability, i.e., (i) on demand; (ii) up to one month; (iii) between one month and three months; (iv) between three months and six months; (v) between 6 months and 12 months, and (v) greater than 12 months. For a given "maturity bucket," the total assets of all banks that exhibit mismatch are added and divided by the total assets of all banks in the sample. The differences between the FSAP and FSA assumptions lie largely in the interpretation of the proposed Basel III measures. 


\section{TOWARD A MORE EFFECTIVE OVERSIGHT FrAMEWORK}

27. The systemic importance, size, and complexity of the U.K. financial markets necessitate the highest quality regulatory and supervisory framework. Domestic and global shocks transmit through the United Kingdom and may be amplified in transmission. Thus, proportionally intense supervision - commensurate with the importance of the U.K.'s global role - is necessary to ensure domestic and global financial stability. ${ }^{9}$

28. In the aftermath of the crisis, the U.K. government decided to overhaul the domestic institutional framework for regulation and supervision. Accordingly, the existing tripartite regulatory regime will be dismantled; the FSA will cease to exist in its current form; and a "three peak" structure will be put in place by end-2012; specifically:

- A new prudential regulator, the Prudential Regulation Authority (PRA), a subsidiary of the BoE, will carry out the prudential regulation of financial firms, including banks, investment banks, building societies, and insurance companies;

- $\quad$ An independent Financial Policy Committee (FPC) will be established at the BoE, with responsibility for regulation of stability of the financial system as a whole;

- A new Financial Conduct Authority (FCA) will regulate the conduct of authorized financial firms providing services to consumers. It will also be responsible for ensuring the good conduct of business in U.K. retail and wholesale financial services, market regulation, and prudential regulation of smaller entities.

29. A key risk is that the transition to the new framework diverts resources from efforts to enhance supervision of the financial sector, which is still in recovery mode. It is critical to build on the progress made on strengthening supervision of the banking and insurance sector; this may require additional supervisory resources. The reform proposal to give explicit and clear mandate for financial stability to the prudential regulator is welcome. However, the broad remit of the new conduct authority may dilute the focus on market regulation and supervision, and prudential supervision of smaller entities. This risks recreating the conditions that resulted in broadening of the FSA's objectives and thus diluting its focus in the lead-up to the crisis. Thus, explicit clarity in legislation is needed.

30. Another concern relates to the challenges in implementing the new governance arrangements to achieve the desired results. While the proposals have built in a variety of cooperation and coordination mechanisms, the experience from other countries suggests the need for one forum for formal and/or informal relationship building, cooperation, and coordination among authorities. These relationships will be necessary for effective governance of the framework. There is no formal crisis management committee established

\footnotetext{
${ }^{9}$ See IMF U.K. Spillover Report for an analysis of spillover risks emanating from U.K. financial sector policies.
} 
in legislation, but coordination mechanisms are in place. A clear locus for all regulatory agencies to interact might also assist the United Kingdom in interacting effectively with the new European Financial Stability Board (EFSB) and with the European Supervisory Authorities (ESAs).

31. The establishment of the FPC is an important step in developing mechanisms to mitigate systemic risk. For the FPC to be credible, it will be important to set realistic expectations of what macroprudential regulation can achieve, especially in its early stages of implementation. A range of macroprudential tools should be considered, given uncertainties regarding their effects and the nature of future risks.

\section{A. Dealing with Too-Important-to-Fail and the International Dimension}

32. Progress has been made in addressing the too-important-to-fail (TITF) problem, but more needs to be done. Regulatory ratios have been strengthened, and a bank levy on wholesale funding has been introduced. Ring fencing of retail operations (a form of retail subsidiarization) and establishment of depositor preference, as proposed by the Independent Commission on Banking, should help improve resolvability of the retail entity. However, ring fencing must be weighed against the costs of such an approach and does not necessarily improve resolvability of the whole entity unless complemented by measures that improve loss-absorption capacity (capital and liquidity surcharges, contingent capital, debt subject to bail-in), recovery and resolution plans, and cross-border resolution arrangements. International collaboration will be critical for progress in these areas and the U.K. authorities should continue exercising leadership on these matters. If such progress is not achieved, there will be a strong push toward more ring fencing and stand-alone subsidiarization which have efficiency and, possibly, financial stability implications.

\section{Central Counter Parties (CCPs) should be subject to robust standards. CCPs} enhance transparency and simplify the complex web of counterparty exposures through multilateral netting and they stand between each counterparty. As a result, they centralize and concentrate counterparty credit risk. Thus, it is vital that they maintain robust prudential and risk-management standards, including financial soundness requirements for access by their members, initial and variation margining, and levying contributions to a default fund. Given their systemic nature, a clear ex-ante framework and contingency plans, including the role of the surviving clearing members, are needed to deal with the implications of their failure. And given their global nature, cross-border coordination is required to avoid regulatory arbitrage and to mitigate systemic risk and adverse spillovers across countries.

34. Oversight of cross-border institutions needs to be improved further. The United Kingdom is a global hub and the authorities' powers vary depending on whether incoming institutions are branches or subsidiaries and whether the parent entity is in the EU or not. While the United Kingdom has strong powers over subsidiaries, it has very limited powers (liquidity supervision only) in relation to EU branches and cannot prevent an incoming EU branch from establishing itself. Equally, the United Kingdom is a major homestate jurisdiction and there will be many host jurisdictions for which U.K. firms play a 
systemic role. Gaps in this domain must be and can only be addressed through international cooperation, in particular across the key financial centers. Better collaboration between home and host authorities, including joint inspections and decision-making processes is needed, as well as enhanced sharing of information using both formalized channels such as colleges and well-developed bilateral contacts. Important issues in cross-border crisis management and resolution remain unresolved, notably on burden sharing and on harmonizing legal frameworks.

35. Investment banking is a particular challenge to cross-border oversight, given the international nature of wholesale and trading activities. Without intensive supervision of investment bank risk taking, domestic and global financial stability cannot be assured. The United Kingdom is one of the major international markets and, as most if not all key players are active in London, the authorities are well placed to have oversight of investment banking activities if efforts at cross-border coordination are taken, so that developing risks in the wholesale markets are not overlooked.

36. The U.K. authorities should continue to work toward an ambitious international package of regulatory reform. The authorities are rightly advocating for European legislation under the EU Capital Requirements Directive (CRD4) that enables the establishment of strong standards that (i) exceed the Basel III minima, including by setting ambitiously high capital requirements together with significantly topped-up capital demands on systemically important financial institutions; and (ii) allows flexibility for national authorities to introduce macroprudential tools, including adjusting capital and liquidity requirements or varying risk weights to address emerging financial and systemic risks. Collaboration with other macroprudential bodies will be important to ensure home-host coordination and reciprocity where appropriate.

\section{B. Improving the Supervision of Banks}

37. Serious deficiencies in risk measurement were revealed by the crisis, as were the shortcomings in supervisors' ability to identify and rectify those deficiencies. Following the Turner Report, the FSA embarked on a program of supervisory enhancement. ${ }^{10}$ This has been articulated as the "intensive and intrusive" approach and "close and continuous supervision" for the larger banks.

\footnotetext{
${ }^{10}$ Financial Services Authority, 2009, The Turner Review: A Regulatory Response to the Global Banking Crisis (London, March).
} 
38. The current supervisory framework was assessed according to the revised Core Principles for Banking Supervision (2006). This is significant for two reasons: (i) the revised principles have a heightened focus on risk management and its practice by supervised institutions, and its assessment by the supervisory authority; and (ii) the standards are evaluated in the context of a financial system's sophistication and complexity vis-à-vis the capacity and resources for adequate oversight of that particular system. These factors should be taken into account in comparing assessments over time and across countries.

\section{The authorities need to continue to address shortcomings in supervisory}

processes. These include clarifying the prudential mandate, improving data quality and the supervisory approach, and techniques and reporting. The Supervisory Enhancement Program (SEP) and the Core Prudential Program (CPP) have recently been put in place by the FSA to overcome these shortcomings. However, there has been insufficient time for these new programs to become adequately embedded. Furthermore, they need to be enhanced with more detailed verification on a proactive basis than appears to be currently planned, better integration of specialist work into the supervision program, and more thematic peer analysis. These efforts should focus on identifying actual or potential risks and addressing riskmanagement deficiencies.

\section{The regulatory authority should be provided with enforcement powers at the}

holding company level. ${ }^{11}$ The FSA's present powers to take supervisory or remedial actions are targeted at the regulated entities that fall within the consolidated group. In other words, the FSA can only impose consolidated obligations by acting through the U.K.-regulated entities, which may not be effective when those entities in the group are small relative to the non-U.K.-regulated entities over which the supervisor has no direct control. Legislation should be amended to provide holding company level enforcement powers.

\section{The FSA has been effective in enhancing the quantity and quality of banks'} capital. Capital rules are compliant with Basel and European requirements, including Basel III trading book capital charges, according to the agreed gradual phase-in schedule, in order to balance the potential adverse implications on lending. The FSA further strengthened capital regulations by promulgating an Interim Capital Regime starting in 2009, based on capital expectations in normal and stressed conditions, which ensures that U.K. banks are well placed to meet the Basel III capital requirements, and approval of dividends and variable remuneration is linked to the outcome of stress tests. The robust stress-testing process for major banks is instrumental in allowing the FSA to set further capital buffers for major banks, above the normal individual capital guidance. Banks are operating with material cushions above the guidance and buffers that appear to be able to withstand severe shocks as prescribed in the FSAP stress tests (see above). The FSA recently introduced formal

\footnotetext{
${ }^{11}$ In the United Kingdom, banking supervision spans the entire range of banking groups' businesses - there is no separation of investment and commercial banking activities as in some other jurisdictions.
} 
guidance regarding reporting, classification, and provisioning for loans subject to lender forbearance.

\section{The FSA has appropriately required regulated banks to build up liquidity} buffers, but liquidity supervision of branches should be improved. Extensive monitoring, stress testing, and assessment of liquidity positions, including the setting of individual bank liquidity guidance, are in place and will be further enhanced. Liquidity positions of major banks have improved. There is a plan for these detailed assessments to be extended to a wider range of high-impact banks, and this needs to proceed expeditiously. However, the FSA does not collect sufficiently detailed liquidity information, even on the large foreign branches that may have systemic relevance for the U.K. financial system. The FSA applied liquidity stress tests to foreign banks' group data before granting "whole firm modifications," whereby it delegated responsibility for liquidity supervision over foreign branches located in the United Kingdom, even though it has powers under EU rules to do so. As a result, the FSA does not have specific information on the activities of U.K. branches of foreign banks, e.g., on rehypothecation, an area in which foreign branches dominate.

43. Achieving the highest standards on home-host relationships is paramount for the United Kingdom, given its central role in the global financial system. The appropriate legal authority to preserve confidentiality is in place. However, there is a need to improve the information sharing between the United Kingdom and other countries on both home and host basis.

\section{Additional supervisory resources - a combination of enhanced skills and}

additional persons - may be needed. Resources in supervision have been increased, as have specialist support resources in various risk areas. The authorities need to agree on a supervisory operating model, as well as the extent of the resource requirements for the new macro-prudential overlay in order to effectively determine further resource needs.

45. The plans to introduce a staged intervention scheme are welcome. The planned scheme will include indicators which, when triggered, will lead to gradually more-intrusive actions by the FSA. The scheme should include an appropriate degree of discretion, but at the same time ensure that appropriate action is taken well before insolvency. It should also include triggers for contacts and coordination actions with other authorities, including the resolution authority and the Financial Services Compensation Scheme (FSCS). ${ }^{12}$

\section{The United Kingdom lags behind many other countries in standards for the} public disclosure of bank data. Such disclosures are important for enabling market discipline - analysts and bank counterparties are now limited in their assessment of the risks being assumed by the banks and of the banks' developments in general. The FSA should

\footnotetext{
${ }^{12}$ See FSAP Technical Note, "Crisis Management and Bank Resolution," for a discussion on what form suitable triggers might take, drawing on cross-country examples.
} 
enhance publication of regular and comparable data on a bank-by-bank basis, including data from prudential returns, whenever appropriate.

\section{Strengthening Insurance Supervision}

47. The new intrusive risk-based approach to supervision applied by the FSA is still in its early stages of implementation. This approach should be extended to a wider range of insurers with careful adjustment to ensure it is applied proportionately to firms of various risk levels, including firms represented across a range of key financial risks. Greater use of indepth analysis should be applied to general insurers. Carrying out more frequent transaction examinations (in relevant areas such as underwriting, reinsurance, claims, and even investments) for both the largest insurers and some of the smaller insurers on a random basis can help reveal problems.

\section{Implementation of Solvency II, on target for 2013, may necessitate additional} resources. The approval of internal models is a crucial step for the insurance industry in this highly specialized and sophisticated market. This will require sufficient resources and expertise to assess and verify models and the adequacy of the resulting capital levels to support a solvent industry.

49. There is a need to improve the scope and frequency of prudential data as well as its disclosure. The published standard return information has not been substantially reviewed for a number of years, in anticipation of Solvency II, which is now on target to be adopted in 2013. Solvency II will lead to a new basis for both qualitative and quantitative reporting, including much greater public disclosure.

\section{Effective Regulation of Securities Markets}

50. Robust market surveillance systems are in place and the FSA has full powers to address market abuse. The FSA has put in place an enhanced enforcement program, beginning in 2007, and this appears to have yielded results in creating a more credible deterrence to improper behavior.

51. Investment firms and managers are subject to risk-based supervision, which appears adequate for firms identified as high impact. Greater attention should be paid to mid-sized firms (across all securities-related activities) and, further, there is a greater need to implement "bottom-up" analysis of firm operations using on-site examinations to supplement the "top-down" risk analysis. While many good supervisory initiatives have been put in place, such as the CPP, these are still taking hold. 


\section{E. Strengthening the Regulation of Financial Market Infrastructures ${ }^{13}$}

52. Financial market infrastructures (FMIs) are governed by a consistent set of laws, regulations, and contractual arrangements. The role and responsibilities for oversight are clearly defined and transparent. Euroclear U.K. \& Ireland Limited, as operator of the securities settlement system, CREST, and recognized CCPs are regulated and supervised by the FSA. Interbank payment systems including the Clearing House Automated Payment System (CHAPS); CLS; Bankers' Automated Clearing Services (BACS); Faster Payment Services (FPS); and those operated as part of CREST, LCH, and ICE are overseen by the BoE.

53. The oversight of FMIs is risk-based. Both the BoE and FSA have taken steps to strengthen supervision since the crisis. For example, the FSA is now analyzing CCPs' internal risk-management models in detail, which had not been the case previously. The FSA is also placing greater emphasis on the quality of close and continuous supervision and the use of regulatory judgment; the need to anticipate and explore issues in a proactive manner; and ongoing supervisory programs around the key issues.

54. The BoE operates the real time gross settlement (RTGS) infrastructure for CHAPS and CREST, as well as settlement of other payment schemes. The RTGS infrastructure also facilitates intraday liquidity transfers, reserve account transfers, transfers in respect of the note circulation system, and transfers that can occur outside of CHAPS operating hours. The BoE assesses the RTGS infrastructure against the CPSS Core Principles through its oversight of recognized systems that rely on the RTGS infrastructure for settlement. This approach is indirect and fragmented and may not include all transactions.

55. The BoE does not agree with the FSAP's recommendation to undertake a direct, unified assessment of the RTGS infrastructure. It does not consider the RTGS to be an interbank payment system but rather an accounting infrastructure that supports some payment systems. It does, however, accept the recommendation to assess the finality of a small number of transfers on RTGS accounts made independently of schemes designated under the Settlement Finality Directive and that these transfers should meet equivalent risk standards. Separately, the BoE intends to conduct in 2011 a unified assessment of the RTGS infrastructure based on its existing internal risk assessment.

56. The U.K. payment and settlement systems are highly tiered, posing vulnerabilities. If a major clearer were to become unavailable, this would likely impose significant liquidity pressures. CHAPS payment flows are very concentrated, with the five most active banks accounting for approximately 80 percent of payment value and the two most active accounting for half of the total value. Consequently, while CHAPS does settle in central bank money, a significant amount of large-value payment activity in the

\footnotetext{
${ }^{13}$ FMIs refer to payment systems, securities settlement systems and central counterparties.
} 
United Kingdom settles in commercial bank money on the books of the main CHAPS members. Exposures to commercial settlement banks are also significantly concentrated in CREST, since two of them account for around 50 percent of the settlement value in sterling. The authorities are well aware of the risks associated with tiering and have made an effort to make banks aware of the risks while encouraging banks with significant activity in the second tier to become direct members. They should institute close monitoring of concentration of payment and settlements activities in banks.

57. Most cash settlement of U.K. CCP transactions (mainly margin calls) is done through commercial bank books (in commercial bank money), which exposes CCPs to intraday credit risk. CCPs should aim to reduce their cash-settlement exposures through settlement in central bank money when possible and practicable.

58. The authorities should work with the CCPs to ensure that other safe and reliable funding options are in place. These should include committed credit lines subject only to presentment, and could also include other options like mutualization of liquidity risk among the CCPs' membership. For moral hazard reasons, the BoE does not want to provide emergency access to overnight central bank liquidity on a pre-arranged basis. However, there is no legal impediment for the BoE to provide emergency liquidity facilities, if deemed necessary, on a discretionary basis. The authorities should also identify in advance what resolution arrangements will apply to CCPs and in what manner and then ensure that all the necessary legal and operational means are implemented.

\section{F. Crisis Management and Resolution}

59. The discount window facility, introduced after the crisis, is filling a useful role and the pre-positioning of collateral facilitates access. The perceived risk of stigmatization of this facility remains an issue - banks avoid using extraordinary funding facilities, so they are not seen by the market as "being in need." The BoE has undertaken to mitigate this effect - for instance, a broad group of institutions has been invited to use the facility on a regular but low-level basis.

60. A permanent liquidity facility was introduced by BoE in June 2010, allowing the use of wider pools of collateral. Counterparties can simultaneously bid for funds against varying collateral sets - a narrow set which comprises high-quality debt and is expected to remain liquid in all but the most exceptional circumstances, and a wider set which comprises high-quality debt that is expected to remain liquid in most circumstances. This facility is also a useful diagnostic tool, as increasing demand for liquidity against the wider pool of collateral could act as an indicator of growing market tension or funding difficulty.

61. The Special Resolution Regime (SRR) provides the authorities with a range of legal tools for the resolution of distressed banks. Of perhaps most significance are the partial property transfer powers (and accompanying creditor safeguards) that: protect depositors; facilitate resolution through transfers of assets and liabilities; permit loss 
allocation to shareholders and other creditors; and also ensure that all creditors are left no worse off than in a liquidation.

62. The authorities should consider establishing resolution tools for other potentially systemically important firms not covered by the SRR. This may include investment banks, insurance firms, and FMIs and perhaps, as needed, money market funds and hedge funds, if of systemic importance (Appendix VI). While the present modalities of the SRR may not fit such firms exactly, certain features of the SRR (particularly the private sector transfer arrangements) could be useful in the resolution of these types of firms. If some sort of equivalent to the SRR were developed for certain designated nonbanks, checks and balances would be needed to address potential moral hazard issues that might stem from designation, and sufficiently strong supervision of designated firms would be imperative.

\section{Powers of the authorities under the SRR to suspend contractual termination} provisions do not currently extend to derivatives contracts. This limitation on SRR powers is due to the strictures of applicable European legislation protecting close-out netting provisions. The authorities noted that the EC is aware of the issue and that EU-wide reform on this technical but important point is being considered.

64. The mandate of the deposit insurance scheme, Financial Services Compensation Scheme (FSCS), is appropriate and operational reforms designed to expedite payouts are commendable. The scheme has been improved after the crisis in a number of ways. In October 2007 in the immediate wake of Northern Rock, the co-insurance aspect of the scheme (whereby the scheme provided only 90 percent coverage beyond the first $£ 2,000$ of any claim) was eliminated. In 2010, further enhancements were made to the FSCS in line with emerging European standards, including: an increase in coverage levels to $£ 85,000$; faster payout rules (targeting payout within 7 days for most claims and within 20 days for the remainder); and gross payouts (ring fencing the deposits of customers holding savings and loans with the same institution). Since the adoption of the Banking Act 2009, the scheme may also - if required to do so by HMT - participate in resolution transactions by providing funding to support transfers of assets and liabilities to a private sector purchaser or a "bridge bank." Further improvements, such as moving to a risk-based premia, need to be considered.

65. FSCS funding is raised ex post, creating survivor bias, and the scheme has standing access to HMT finance. FSCS coverage levels are in line with EU Directives and FSCS is working with U.K. banks to develop operational systems that provide a "single depositor view" that should permit more rapid satisfaction of depositor claims.

66. The recently introduced bank levy is to be regarded as a tax on banks and is not intended to build any fund to finance future bank resolution costs. The levy carries similar features as the IMF proposal to the G20 for a financial stability contribution. ${ }^{14}$ It is

\footnotetext{
${ }^{14}$ A Fair and Substantial Contribution by the Financial Sector: Final Report for the G-20, IMF, June 2010.
} 
based on U.K. banks' consolidated accounts — on global balance sheets, not solely on their U.K. operations - as well as the U.K. operations of banks from other countries. The levy is designed to target risky funding models and there are a number of features consistent with this, including the exclusion of tier 1 capital and stable deposits from the liability base subject to the levy. It is, however, not linked to a credible and effective resolution mechanism as proposed by the IMF. Rather than act as a fund for the direct costs of resolving any individual bank failure, the levy is intended to ensure that banks make a contribution with respect to the potential risks they pose to the U.K. financial system and wider economy. The levy should be further refined to reflect individual institutions' riskiness and contributions to systemic risk — such as those related to size, interconnectedness, and substitutability — and variations in overall risk over time.

\section{G. Anti-Money Laundering and Combating the Financing of Terrorism Framework}

\section{The anti-money laundering and combating the financing of terrorism} (AML/CFT) framework of the United Kingdom was evaluated by the Financial Action Task Force (FATF) in 2006/2007. The FATF June 2007 mutual evaluation report (MER) indicates that, overall, the United Kingdom had a comprehensive AML/CFT system in place, but that further improvements were nevertheless needed; weaknesses were notably identified with respect to customer due diligence (CDD) measures in the financial sector, and supervision of small financial institutions. ${ }^{15}$

68. The United Kingdom updated its AML CFT legislation in 2007 with the issuance of the new Money Laundering Regulations (MLRs). These regulations strengthened the legal arrangements within the United Kingdom in order to further improve compliance with the FATF Recommendations and implement, in part, the Third EU Money Laundering Directive ${ }^{16}$ Since the evaluation, the progress made by the U.K. authorities in addressing the most significant deficiencies identified in the MER was analyzed by the FATF in two followup reports, respectively, in June and October 2009. These reports indicate that, overall, significant progress had been made. In particular, the deficiencies noted with respect to CDD have been addressed. In addition, the FSA commenced a project looking at AML/CFT systems and controls in small firms: 159 small firms were selected across the wholesale and retail sectors and a report was published in May 2010. The FSA's Financial Crime Operations Team now routinely visits small firms as part of its case work and ongoing thematic work, and has visited a total of 337 firms from 2007 to 2010.

\footnotetext{
15 The June 2007 mutual evaluation report is the latest available comprehensive AML/CFT assessment of the United Kingdom. A Technical Note, "Anti-Money Laundering/Combating the Financing of Terrorism," has been prepared to provide an update of the findings and follow up on the mutual evaluation report.

${ }^{16}$ Directive 2005/60/EC of the European Parliament and of the Council on the prevention of the use of the financial system for the purpose of money laundering and terrorist financing.
} 


\section{Box 1. Did Trading Activities Increase the Vulnerability of Banks to Financial Stress?1/}

The increasing involvement by banks in leveraged trading activities in the lead-up to the crisis is largely seen to have played an important role in the financial stress many experienced. A survey by the FSA of 10 investment banks suggests that some $\$ 240$ billion of losses on trading positions between January 2007 and March 2009 were attributable to structured credit products, mostly linked to the U.S. housing market.2/ Work done at the Fund in this area includes empirically testing the hypothesis that banks with significant trading businesses may have been potentially more vulnerable to shocks:

- The sample comprises 79 banks across Asia, Europe, and the United States, and includes commercial, investment, and universal banks. Asian banks - which have remained resilient through the crisis - are used as a control group to determine if the hypothesis holds.

- The proportion of total trading income to total revenue is first calculated for each bank to determine the extent of the bank's overall revenue source, which may be susceptible to market fluctuations.3/

- A filter rule test then is applied to identify potentially vulnerable banks - any bank whose share of trading income to total revenue ratio in 2008 exceeds the defined filters is deemed to fall in this category.4/

- $\quad$ These institutions are then compared against those that received official support in 2008-09.

Two separate filter rules—one and two standard deviation (SD) filters—are applied in the tests (Box Table 1):

- When the 1 *SD filter is applied, 72 percent of European LCFIs that are identified as having been potentially vulnerable actually required official assistance. In this group, the vulnerability of four out of seven U.K. banks are highlighted, and three of them did eventually receive government support. The proportion for U.S. banks is similar at 67 percent, but is very different for Asia, where only one out of the eight banks (13 percent) identified by the rule actually received official support.5/

- When the $2 * \mathrm{SD}$ filter is imposed to capture banks with most significant trading businesses, the predictive ability for Europe in general, and the United Kingdom in particular, remains the same but improves for both U.S. and Asian banks to 80 percent and 33 percent, respectively.

The results provide some support for the importance of trading activities in increasing the vulnerability of banks during the recent crisis. Given that the findings for Asian banks are less supportive of the hypothesis, other factors clearly play an important role as well, e.g.:

- Economic fundamentals - Asian economies were more resilient during the crisis, possibly because they were in a different business cycle relative to Europe and the United States, which underpinned the overall health of the region's banking systems.

- The quality of assets and earnings - Asian banks typically had low exposure to toxic assets such as subprime mortgages, residential mortgage-backed securities (RMBS), and their derivatives, which may have helped them weather the shocks.

In theory, trading activity-when undertaken with proper risk management and monitoring-should promote efficient price discovery and enhance the breadth and depth of securities, derivatives, and structured products markets, and thus provides a valuable service. Thus, any tightening in prudential regulations against banks' trading activities should consider the following issues: (i) potential vulnerabilities

Box 1. Did Trading Activities Increase the Vulnerability of Banks to Financial Stress? 


\section{(Concluded)}

arising from trading for market-making, pure proprietary trading, hedging or rehypothecation activities; (ii) improving transparency by mandating the reporting of trading income by types of transaction; and (iii) the possibility of imposing capital charges based on business lines and the nature and riskiness of their respective activities.

\begin{tabular}{|c|c|c|c|c|c|c|c|c|c|}
\hline & & \multirow{2}{*}{\multicolumn{4}{|c|}{$1 * S D$ filter }} & \multicolumn{4}{|c|}{$2^{*} \mathrm{SD}$ filter } \\
\hline & & Number of & & & g Income in & Number of $\mathrm{B}$ & ks with $P$ & centage Tradi & g Income in \\
\hline & & $\begin{array}{c}\text { Asia } \\
\text { (including } \\
\text { Australia \& } \\
\text { Japan) }\end{array}$ & $\begin{array}{l}\text { United } \\
\text { States }\end{array}$ & $\begin{array}{c}\text { Europe } \\
\text { (incl. United } \\
\text { Kingdom) }\end{array}$ & $\begin{array}{c}\text { United } \\
\text { Kingdom } \\
\text { only }\end{array}$ & $\begin{array}{c}\text { Asia } \\
\text { (including } \\
\text { Australia \& } \\
\text { Japan) }\end{array}$ & $\begin{array}{l}\text { United } \\
\text { States }\end{array}$ & $\begin{array}{c}\text { Europe } \\
\text { (incl. United } \\
\text { Kingdom) }\end{array}$ & $\begin{array}{c}\text { United } \\
\text { Kingdom } \\
\text { only }\end{array}$ \\
\hline A & $\begin{array}{l}\text { Number of potentially vulnerable banks as identified by the } \\
\text { filter rule }\end{array}$ & 8 & 6 & 25 & 4 & 3 & 5 & 21 & 4 \\
\hline B & $\begin{array}{l}\text { Number of banks which actually received official support in } \\
2008-09\end{array}$ & 1 & 5 & 23 & 3 & 1 & 5 & 23 & 3 \\
\hline c & $\begin{array}{l}\text { Number of potentially vulnerable banks as identified by the } \\
\text { filter rule which received official support in } 2008-09\end{array}$ & 1 & 4 & 18 & 3 & 1 & 4 & 15 & 3 \\
\hline C/A & Predictive ability of the filter rule (in percent) & 12.5 & 66.7 & 72.0 & 75.0 & 33.3 & 80.0 & 71.4 & 75.0 \\
\hline
\end{tabular}

Sources: Bloomberg; and IMF staff calculations.

Note: Sample taken from 1999-2007. United States, 15 banks; Europe (including United Kingdom), 46 banks; Asia (including Australia \& Japan), 18 banks; United Kingdom, 7 banks.

1/ Prepared by Julian Chow (IMF/MCM).

2/ See Financial Services Authority, 2011, Prudential Risk Outlook (London, March).

3/ The majority of banks do not distinguish between proprietary trading and hedging activities in trading income, which means that the reported "total trading income" figures comprise revenues from valuation of securities held in the "Trading Book", net realized gains/losses from proprietary trading activities, and disposal of "Available-for-Sale" securities and mark-to-market valuation of derivatives for "hedging."

4/ The methodology requires the computation of means and standard deviations (SD) of trading income-to-total revenue ratios for the period between 1999-2007 with the filter rule defined as: Mean $+k^{*} \mathrm{SD}$ where $k=1$ in and $k=2$.

5/ The U.K. banks sample consists of HSBC Group, Barclays, RBS, LBG, Standard Chartered Bank (SCB), HBOS, Nationwide. 


\section{Box 2. Systemic Risk and the U.K. Banking System 1/}

The United Kingdom, as one of the world's biggest and most open financial centers, dominates international financial market activity in many areas and is also an important home and host country to some of the biggest financial institutions in the world. The very high volume of financial transactions that take place in the United Kingdom, combined with the increasing inter-linkages across both the local and international financial systems, mean that distress affecting the U.K. businesses of any large financial institution could be transmitted both locally and overseas. Conversely, the United Kingdom's role as a center for global finance raises the possibility that it may potentially be exposed to significant spillovers or "contagion," from stresses originating elsewhere in the global financial system.

We estimate the market's perception of systemic risks associated with the U.K. banking system by constructing indicators with CDS and equity data.2/ The methodology is based on a nonparametric empirical copula, which measures coincidence of dispersion ("entropy") of a time series of default probability observations across multiple entities. It captures both linear and nonlinear dependence between financial institutions and the changes through the economic cycle, which reflect increasing dependence during periods of stress.3/ Specifically, we calculate: (i) the Joint Probability of Distress (JPoD), which is the probability that all banks in the sample experience distress simultaneously (i.e., the "tail risk"); and (ii) the Conditional Probability of Distress (CoPoD), which presents the conditional probability of distress of an institution, given that another institution becomes distressed.

Our sample consists of major U.K. banks and foreign Large Complex Financial Institutions (LCFIs). To be consistent with the BoE's Financial Stability Report, we define the major U.K. banks peer group ("U.K. banks") based on the provision of customer services in the United Kingdom - regardless of the country of ownership - and the LCFIs to include the world's largest financial institutions from other European countries ("European LCFIs") and the United States ("U.S. LCFIs") that carry out a diverse and complex range of activities in major financial centers.4/ The market-price based results suggest that:

- Systemic tail risks within the U.K. banking system - which we define as the market's estimated probability that all U.K. banks would default at the same time - increased during the crisis but have receded significantly since. These risks peaked in 2009 Q1 at the height of interventions by HMT, through the Asset Protection Scheme (APS) and the recapitalization of LBG, and when funding markets beyond three months were closed to all major U.K. banks. Fears of sovereign debt crises among some EU states also increased during that period and then intensified again around mid-2010 when the crisis in Greece came to a head and Ireland experienced significant stress, but fell sharply in subsequent months (Box Figure 1). Risk perceptions improved after Greece, and then Ireland, sought loans from the EU and IMF.

- Individual U.K. banks appear to have become more susceptible to distress spillovers from other major financial institutions since the onset of the crisis, but their exposures have moderated somewhat since 2010 Q2. On average, the CoPoD of a particular U.K. bank, given that another major financial institution in the United Kingdom, Europe, or the United States becomes distressed, has decreased in recent months but remain elevated compared to pre-crisis levels (Box Figure 2). Notwithstanding the fact that actual exposures among U.K. banks have fallen, they continue to be seen as being more exposed to one another and to European LCFIs, than to U.S. LCFIs.

- $\quad$ The implied spillover threat posed by U.K. banks to foreign LCFIs rose sharply over the course of the crisis, but has fallen markedly back down to almost pre-crisis levels. Interestingly, U.S. LCFIs appear to have been more exposed to U.K. banks, on average, during the crisis, compared to their European counterparts (Box Figure 3). Since then, the average derived probability that a default in a U.K. bank would have systemic consequences for a foreign LCFI has declined to around 20 percent for both European and U.S. LCFIs, from 40 and 50 percent, respectively, at the height of the crisis.

The results point to heightened spillover risks arising from interconnectedness between the U.K. banks and European and U.S. LCFIs during periods of stress. The findings emphasize the importance of ensuring that an adequate crisis management and resolution framework is in place to deal with any problems that may arise from shocks to the domestic or international financial system; and reveal the greater exposure of the U.K. banking system 


\section{Box 2. Systemic Risk and the U.K. Banking System (Concluded)}

to the European banks, underscoring the need to continually improve collaboration and coordination with other European countries.5/

\section{Box Figure 1. Probability that All U.K. Banks in the Sample Default at the Same Time}

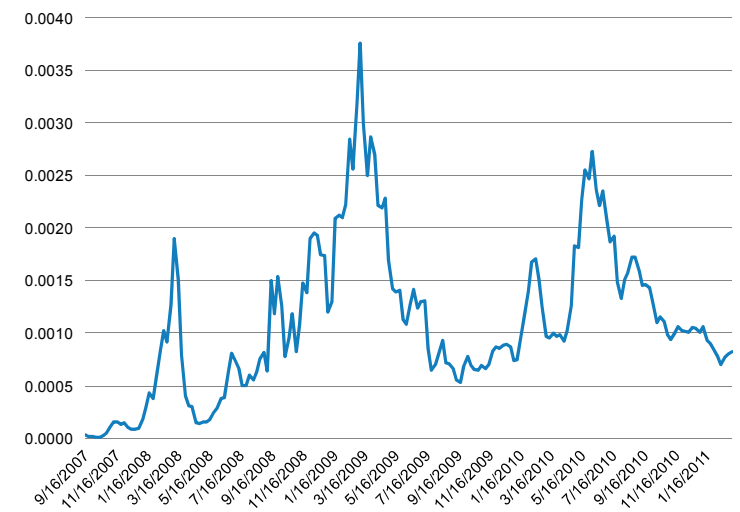

Sources: Bloomberg; Markit; and IMF staff calculations.

Box Figure 2. Probability of Default of a Particular U.K. Bank Conditional on the Default of Another U.K. Bank, a U.S. or European LCFI

(Averaged across sample)

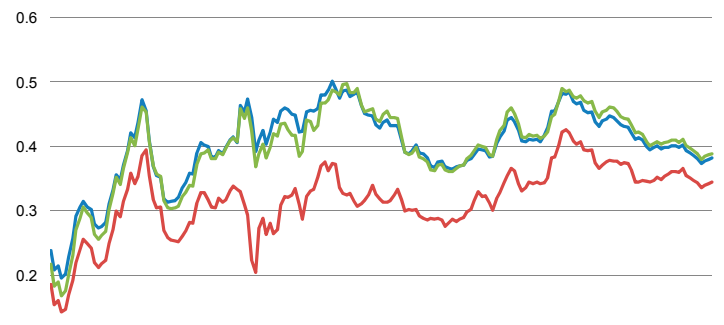

$$
0.1
$$

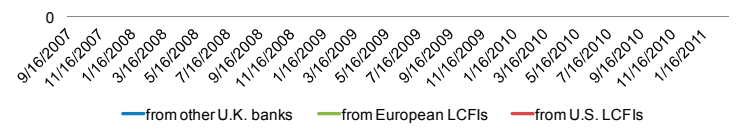

Sources: Bloomberg; Markit; and IMF staff calculations.
Box Figure 3. Probability of Default of a U.K. Bank, U.S. or European LCFI Conditional on the Default of a Particular U.K. Bank (Averaged across sample)
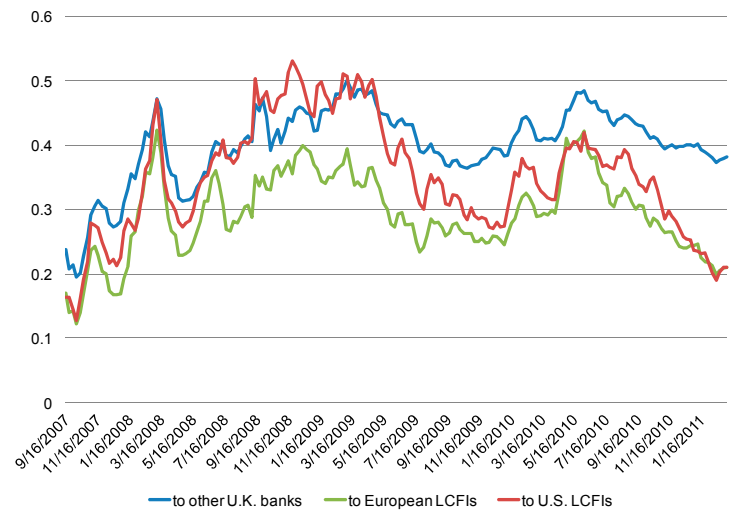

Sources: Bloomberg; Markit; and IMF staff calculations.

1/ Prepared by Hiroko Oura and Ryan Scuzzarella (both IMF/MCM).

2 / The analysis is based on information contained in market prices of CDS and equities, rather than any actual information on the actual business inter-linkages among banks.

3/ See Segoviano, Miguel and Charles Goodhart, 2009, “Banking Stability Measures,” IMF Working Paper No. 09/04 (Washington: International Monetary Fund).

4/ This U.K. banks peer group comprises Banco Santander, Bank of Ireland, Barclays, Hong Kong and Shanghai Banking Corporation (HSBC) Holdings, Lloyds Banking Group (LBG), National Australia Bank, Nationwide Building Society, Northern Rock and Royal Bank of Scotland (RBS); Co-operative Financial Services is omitted as CDS spreads are unavailable, while the FTSE100 share price index is used as proxy for Nationwide's share price. The LCFIs comprise: BNP Paribas, Credit Suisse, Deutsche Bank, Société Générale and UBS (all Europe); and Bank of America, Citigroup, Goldman Sachs, JPMorgan Chase \& Co., Morgan Stanley (all United States).

5/ It should be noted that the construction of distress dependence metrics such as JPoDs and CoPoDs do not account for the stochastic nature of actual recovery rates and the price of risk (moving from risk-neutral to real world probabilities of default). This would suggest that probabilities of distress could be over-estimated on some occasions but under-estimated at other times. 


\section{Box 3. Vulnerabilities of U.K. Household and Corporate Balance Sheets and Risks to the Financial Sector 1/}

The financial crisis had a significant effect on U.K. household and corporate sector balance sheets. Although the process of balance sheet repair is well underway, vulnerabilities remain in both sectors, particularly in commercial real estate, unsecured household debt, and some segments of the mortgage debt market. A key concern is that any stress in these segments - which could be triggered by a rapid increase in interest rates, a sustained rise in unemployment, a sharp decline in real estate prices, or a combination thereof - could have a significant impact on the health of the banking sector, both directly and indirectly through feedback loops between the real and financial sectors.

In the household sector, pockets of vulnerability exist in unsecured household debt and some segments of the mortgage market:

- Household debt relative to disposable income remains high by both international and U.K. historical standards, leaving households vulnerable to income and interest rate shocks. While unsecured debt is a relatively small share of bank lending to U.K. resident sectors (5 percent), absolute losses from unsecured debt have so far surpassed losses from mortgage defaults, which have remained low relative to previous crises. Since low-income households account for just over a quarter of banks' unsecured lending to households, banks could sustain some losses if interest rates were to normalize rapidly to or above pre-crisis levels (Box Figure 4)

- With the ratio of house prices to income still significantly above the historical average, further sharp declines in house prices could impact household balance sheets. Although house price shocks do not directly affect household debt service capacity, the empirical evidence shows that arrears in the North and in Wales, which have experienced large house price declines and a slower housing market recovery, are higher than in other regions. Thus, a combined shock that would affect both household debt service capacity—such as an increase in unemployment —and the collateral value of secured debt could have a material impact on banks' asset quality.

- Risky borrowers, such as those with high loan-to-value (LTV) or buy-to-let loans, have tended to post higher arrears and represent yet another source of credit risk for banks.

\section{Box Figure 4. United Kingdom: Breakdown of Bank Lending to Residents by Borrower}

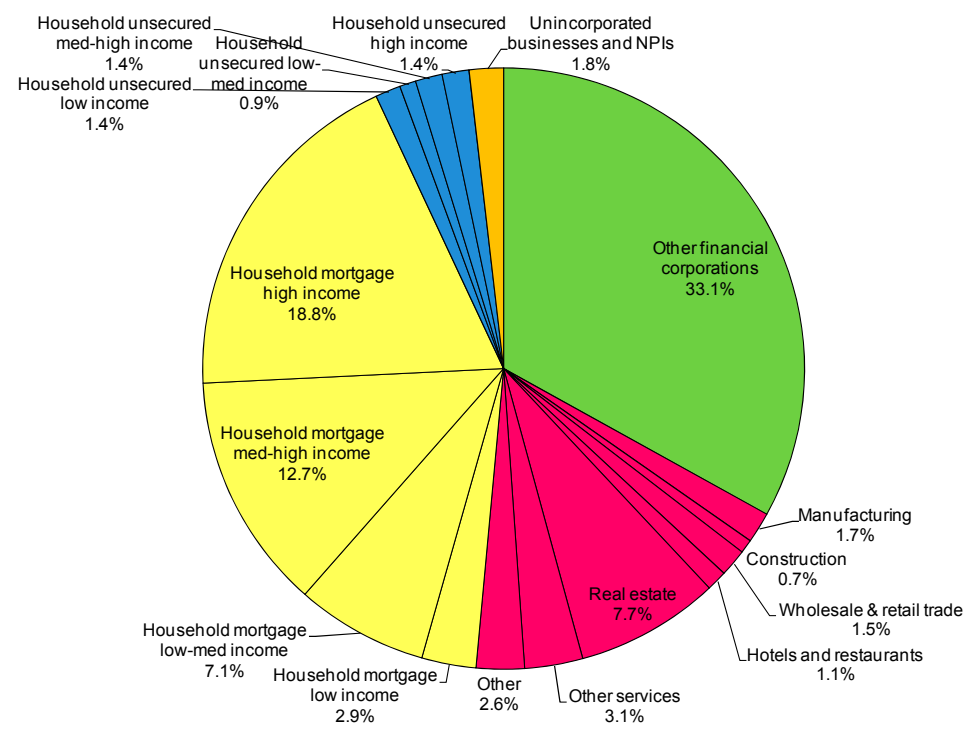

Sources: BoE; 2010 NMG Consulting survey; and IMF staff estimates.

Our sensitivity analysis of increases in interest rates and income shocks suggests that loan losses from household mortgages for the banking sector would be manageable, but that a house price shock could result in significant threat to banks' asset quality. 2/ That said, any knock-on effect from the manifestation of these shocks on banks, while 


\section{Box 3. Vulnerabilities of U.K. Household and Corporate Balance Sheets and Risks to the Financial Sector (Concluded)}

likely to be nonnegligible, would be mitigated to a large degree given that (i) most household bank debt is secured; and (ii) low-income households, which are most sensitive to interest rate and income shocks, account for a relatively small proportion of bank mortgage lending (Box Figure 5).

Meanwhile, the corporate sector as a whole weathered the crisis relatively well, and leverage has subsequently declined and profitability strengthened. The increase in the number of company liquidations during the crisis was moderate compared to previous crises and has been declining since late-2009, supported by the low interest rate environment. The sector appears relatively resilient to interest rate shocks while debt-at-risk-i.e., where the interest cover ratio (ICR) is less than one - appears relatively insensitive to declines in profitability: A 300 basis points increase in interest rates would increase debt-at risk by 3 percentage points, and a 30 percent decline in profits would increase debt-atrisk by 2 percentage points. Contingent claims analysis (CCA), which combines balance sheet and equity market information to obtain forward-looking measures of the risk of default, also suggests that the market expects losses from corporate defaults one year ahead to be limited to between 0.2 percent to 0.7 percent of GDP.

One important exception is the corporate real estate (CRE) sector. Both sensitivity analyses and CCA suggest that macroeconomic shocks would disproportionately affect this sector, which is still recovering from the crisis (Box Figure 6). CRE represents almost half of total bank loans to the nonfinancial corporate sector, and with a large share of those loans due to be refinanced over the next few years, a large funding gap may arise if banks are unwilling or unable to roll over or restructure loans. The CRE remains exposed to further declines in prices - despite the recent rebound, it remains substantially below its peak and many borrowers are in negative equity or in breach of LTV covenants. An important mitigating factor is that the real estate sector represents a relatively small share of total corporate sector liabilities and less than 8 percent of bank loans to U.K. residents.

It is important to note that financial distress and credit risks in the household and CRE sectors may actually be larger than suggested by the headline figures of write-offs and liquidations. The concentration of credit risks in some large banks and the widespread practice of lender forbearance may understate these risks. Lenders forbearance, where lenders overlook breaches in LTV covenants or evergreen loans, has played a material role in containing defaults to date, particularly in the CRE sector. Moreover, CRE lending is very concentrated, with a few big banks accounting for a large share of the outstanding debt. Banks with large exposures could thus be hard hit if economic and market conditions were to deteriorate sharply. Additional risks could also crystallize from significant exposures to real estate markets outside the United Kingdom.

\section{Box Figure 5. United Kingdom: Share of Mortgage Debt-at- Risk by Income Group}

(In percent)

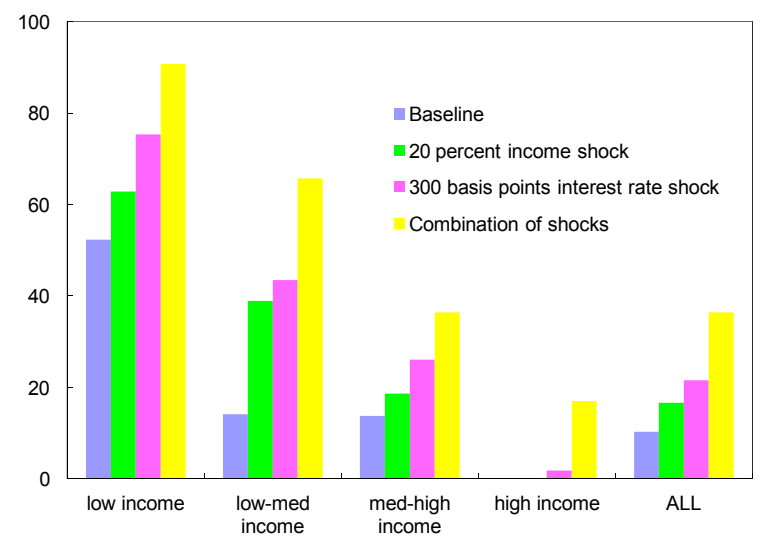

Sources: 2010 NMG Consulting Survey; and IMF staff estimates.
Box Figure 6. United Kingdom: Share of Debt-At-Risk of Non-Financial Corporates by Sector

(In percent)

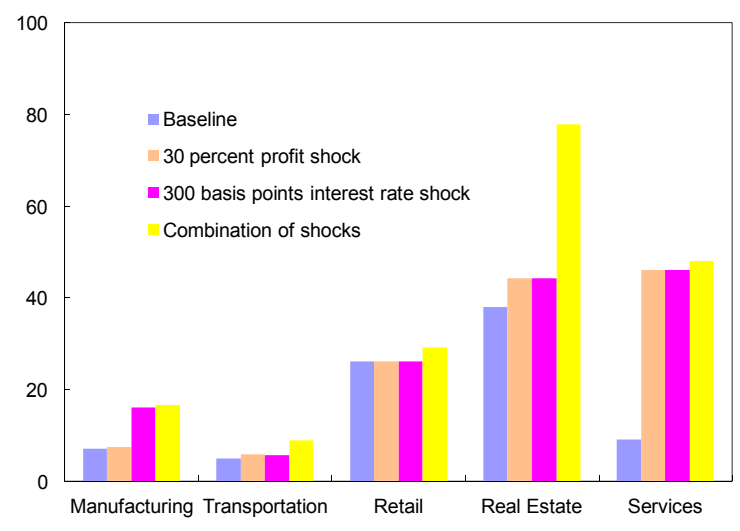

Sources: Worldscope; and IMF staff estimates.

1/ Prepared by Marta Ruiz-Arranz (IMF/EUR). See FSAP Technical Note, "Vulnerabilities of Household and Corporate Balance Sheets and Risks for the Financial Sector."

2/ The analysis assumes an extreme 300 basis points rise in interest rates (well above the 60-65 basis points rise in interest rates assumed in the more severe scenarios in the solvency stress test of the banking sector); a 20 percent drop in income; and a 20 percent fall in house prices. 


\section{APPENDIX I: UNITED KINGDOM: RISK ASSESSMENT MATRIX}

\begin{tabular}{|c|c|c|}
\hline \multirow{2}{*}{$\begin{array}{l}\text { Nature/Source of Main } \\
\text { Threats }\end{array}$} & \multicolumn{2}{|c|}{ Overall Level of Concern } \\
\hline & $\begin{array}{c}\text { Likelihood of Severe Realization of } \\
\text { Threat in the Next } 1-3 \text { Years } \\
\text { (high, medium or low) }\end{array}$ & $\begin{array}{c}\text { Expected Impact on Financial } \\
\text { Stability if Threat is Realized } \\
\text { (high, medium or low) }\end{array}$ \\
\hline $\begin{array}{l}\text { 1. Global "double-dip" } \\
\text { recession. }\end{array}$ & $\begin{array}{l}\text { Staff assessment: Medium } \\
\text { - The IMF WEO projections place a } \\
\text { low probability on a double-dip } \\
\text { recession. } \\
\text { - The United Kingdom would be } \\
\text { exposed to a drop in demand for its } \\
\text { exports and financial services. }\end{array}$ & $\begin{array}{l}\text { Staff assessment: Medium } \\
\text { - The solvency stress tests suggest } \\
\text { that the major banks would be able } \\
\text { to absorb losses due to a severe } \\
\text { double-dip recession. However, } \\
\text { the realization of extreme "tail of } \\
\text { the tail" risks could result in a } \\
\text { capital shortfall of up to } 1.6 \text { percent } \\
\text { of } 2010 \text { GDP relative to Basel III } \\
\text { Tier } 1 \text { hurdle rates (and up to } 1.8 \\
\text { percent of GDP relative to FSA } \\
\text { requirements). }\end{array}$ \\
\hline $\begin{array}{l}\text { 2. Continued slow } \\
\text { growth and sustained } \\
\text { low interest rates. }\end{array}$ & $\begin{array}{l}\text { Staff assessment: Medium } \\
\text { Medium-term growth could be quite } \\
\text { sluggish and not pick up as } \\
\text { projected in the IMF staff's central } \\
\text { scenario, as headwinds from } \\
\text { household, bank, and public-sector } \\
\text { balance sheet repair weigh on } \\
\text { domestic demand. In this scenario, } \\
\text { interest rates could remain quite low } \\
\text { for an extended period. }\end{array}$ & $\begin{array}{l}\text { Staff assessment: Low } \\
\text { - The FSA's stress tests suggest } \\
\text { that most insurers would be } \\
\text { resilient to this scenario. } \\
\text { - The solvency stress tests suggest } \\
\text { that banks have sufficient buffers } \\
\text { to accommodate prolonged slow } \\
\text { growth. At the extreme tail, the } \\
\text { capital shortfall would be less than } \\
1 \text { percent of GDP. }\end{array}$ \\
\hline $\begin{array}{l}\text { 3. Inability of banks to } \\
\text { meet refinancing needs. }\end{array}$ & $\begin{array}{l}\text { Staff assessment: Medium and rising } \\
\text { - The outlook for market access } \\
\text { remains highly uncertain, with the } \\
\text { continuing turmoil in the Eurozone } \\
\text { making issuance and rollovers } \\
\text { difficult. U.K. banks have significant } \\
\text { refinancing needs through end-2014, } \\
\text { including public support schemes. }\end{array}$ & $\begin{array}{l}\text { Staff assessment: High } \\
\text { - FSAP liquidity stress tests applying } \\
\text { Basel III standards suggest that } \\
\text { sustained pressures in wholesale } \\
\text { funding markets could expose } \\
\text { vulnerabilities-institutions } \\
\text { representing almost } 70 \text { percent of } \\
\text { assets lack sufficient stable } \\
\text { funding beyond six months. }\end{array}$ \\
\hline $\begin{array}{l}\text { 4. Significant } \\
\text { deterioration in real } \\
\text { estate prices. }\end{array}$ & $\begin{array}{l}\text { Staff assessment: Medium } \\
\text { - Commercial real estate (CRE) prices } \\
\text { have rebounded somewhat from its } \\
40 \text { percent decline but the outlook } \\
\text { with respect to rent levels and } \\
\text { occupancy remain uncertain. } \\
\text { - House price-to-rent and price-to- } \\
\text { income ratios are still about } 30 \\
\text { percent above their historical } \\
\text { averages. However, a full return to } \\
\text { historical averages is not the central } \\
\text { scenario, as rich valuations partly } \\
\text { reflect tight planning restrictions and } \\
\text { low interest rates, which are likely to } \\
\text { remain below pre-crisis levels for } \\
\text { some time. Nonetheless, a large } \\
\text { deterioration in house prices is a } \\
\text { risk, especially if interest rates rise } \\
\text { significantly. }\end{array}$ & $\begin{array}{l}\text { Staff assessment: Medium } \\
\text { - Loans to CRE account for around } \\
\text { half of all domestic lending to } \\
\text { nonfinancial corporate and about a } \\
\text { fifth of total banking sector loans. } \\
\text { The FSAP analysis indicates that } \\
\text { macroeconomic shocks would } \\
\text { disproportionately affect CRE. } \\
\text { - The FSAP analysis indicates that } \\
\text { low income households are most } \\
\text { sensitive to house price declines } \\
\text { and real interest rate shocks. } \\
\text { - Current lender forbearance } \\
\text { practices could be masking } \\
\text { increased risks in both markets. }\end{array}$ \\
\hline
\end{tabular}




\begin{tabular}{|c|c|c|}
\hline \multirow{2}{*}{$\begin{array}{l}\text { Nature/Source of Main } \\
\text { Threats }\end{array}$} & \multicolumn{2}{|c|}{ Overall Level of Concern } \\
\hline & $\begin{array}{l}\text { Likelihood of Severe Realization of } \\
\text { Threat in the Next } 1-3 \text { Years } \\
\text { (high, medium or low) }\end{array}$ & $\begin{array}{l}\text { Expected Impact on Financial } \\
\text { Stability if Threat is Realized } \\
\text { (high, medium or low) }\end{array}$ \\
\hline $\begin{array}{l}\text { 5. Intensified sovereign } \\
\text { and banking sector } \\
\text { distress in EU periphery } \\
\text { countries or the bursting } \\
\text { of the asset bubble in } \\
\text { Asia. }\end{array}$ & $\begin{array}{l}\text { Staff assessment: Medium and rising } \\
\text { - Sovereign and financial sector } \\
\text { distress in countries with weak } \\
\text { fundamentals and debt-sustainability } \\
\text { problems could worsen in the } \\
\text { absence of a consistent and } \\
\text { cohesive European approach to } \\
\text { restore confidence, leading to } \\
\text { contagion, both nationally and } \\
\text { across borders. U.K. banks' direct } \\
\text { exposure to vulnerable European } \\
\text { countries amount to more than } 50 \\
\text { percent of core tier } 1 \text { capital. The } \\
\text { two largest foreign-owned banks are } \\
\text { Santander U.K. (household } \\
\text { exposures) and Allied Irish } \\
\text { (corporate exposures). } \\
\text { - Strong capital inflows into Asia are } \\
\text { continuing to fuel asset bubbles in } \\
\text { several countries in that region. }\end{array}$ & $\begin{array}{l}\text { Staff assessment: High } \\
\text { - The solvency stress tests suggest } \\
\text { that risks from banks' exposures to } \\
\text { vulnerable European sovereigns } \\
\text { seem manageable but spillovers to } \\
\text { the private sector in those } \\
\text { countries and to core European } \\
\text { banks could have major } \\
\text { implications. FSAP stress tests } \\
\text { suggest that the realization of } \\
\text { extreme tail risks under the more } \\
\text { adverse scenarios could result in } \\
\text { some capital shortfall. } \\
\text { Banks are also vulnerable to } \\
\text { sustained funding disruptions from } \\
\text { the realization of sovereign risks. } \\
\text { Two of the largest U.K. banks have } \\
\text { very large exposures to Asia, but } \\
\text { are relatively less exposed to the } \\
\text { United Kingdom. }\end{array}$ \\
\hline $\begin{array}{l}\text { 6. Uncertain impact of } \\
\text { ongoing regulatory } \\
\text { reforms. }\end{array}$ & $\begin{array}{l}\text { Staff assessment: Medium } \\
\text { - Basel III implementation will be } \\
\text { phased in over time but the U.K. } \\
\text { authorities are considering an } \\
\text { acceleration of the process and } \\
\text { imposing further requirements on } \\
\text { systemically-important financial } \\
\text { institutions (SIFls). } \\
\text { - The ICB has proposed ring-fencing } \\
\text { of retail banking operations in its } \\
\text { interim report. Final report is } \\
\text { expected in September. } \\
\text { - Solvency II will come into force for } \\
\text { insurance firms by January } 1,2013 \text {, } \\
\text { and could have unintended } \\
\text { consequences for their financial } \\
\text { performance. } \\
\text { - Operational risk continues to rise as } \\
\text { the uncertainty surrounding } \\
\text { regulatory and supervisory reforms } \\
\text { has resulted in higher than previous } \\
\text { staff attrition from the FSA, and the } \\
\text { exodus could continue. }\end{array}$ & $\begin{array}{l}\text { Staff assessment: Medium } \\
\text { - The solvency stress tests indicate } \\
\text { that the major banks are well- } \\
\text { placed to meet Basel III } \\
\text { requirements. } \\
\text { - The FSAP liquidity stress tests } \\
\text { confirm banks' vulnerabilities at } \\
\text { six-month maturities and beyond. } \\
\text { - The ICB deliberations (which could } \\
\text { result in the breaking up of banking } \\
\text { groups) may be unsettling for } \\
\text { funding markets. } \\
\text { - The proposed risk weights are } \\
\text { expected to encourage insurers to } \\
\text { hold more low-yielding assets, } \\
\text { such as sovereign bonds. Given } \\
\text { the low interest rates, this could } \\
\text { encourage risk taking as insurers } \\
\text { seek to meet nominal returns and } \\
\text { offset underwriting competition. } \\
\text { - Loss of experienced human } \\
\text { capital, including some of the } \\
\text { FSA's most senior staff, could } \\
\text { negatively impact the quality of } \\
\text { supervision under a reformed } \\
\text { regime where emphasis is placed } \\
\text { on the leadership. }\end{array}$ \\
\hline
\end{tabular}




\section{ApPendix II: United Kingdom: Key Policy Measures Taken DURIng The Crisis}

\section{Policy actions taken by the U.K. authorities during the crisis to stabilize the financial system include (but are not limited to) the following:}

- $\quad$ The BoE provided temporary liquidity support as a lender of last resort to Northern Rock in 2007 and to HBOS and RBS in 2008. Collateralized loans to the latter two banks reached a combined maximum amount of nearly $£ 62$ billion in October 2008 , but were repaid by mid-January 2009.

- In April 2008, the BoE introduced exceptional liquidity support through the SLS to allow banks to swap their high-quality but illiquid mortgage-backed and other securities for U.K. treasury bills for up to three years. The SLS was extended in October 2008, leading to a total utilization of $£ 185$ billion by the end of the drawdown period on January 30, 2009. At end-May 2011, £37 billion remained outstanding, with banks ahead of their voluntary repayment plans agreed with the BoE. The SLS will expire at the end of January 2012.

- $\quad$ Additional funding support was introduced by HMT through the CGS in October 2008, providing government guarantees for short- and medium-term debt (one month up to three years) issued by banks. The CGS closed to new issuance at end-February 2010 and, as at December 2010, the total debt guaranteed under the scheme was $£ 115$ billion. Eligible institutions can still finance debt already guaranteed under the scheme without restriction until April 2012, and until April 2014 conditional on total scheme drawdown remaining below $£ 83.3$ billion.

- In January 2009, the government created the APS to provide participating institutions with protection against future credit losses on defined portfolios of assets in exchange for a fee. The initial plan insured $£ 260$ billion of assets from LBG and $£ 325$ billion of assets from RBS. LBG subsequently took steps not to participate in the scheme, while the conditions for RBS were reviewed - the insured assets amounted to $£ 282$ billion as at December 31, 2008 and first loss protection increased to $£ 60$ billion, covering 90 percent of subsequent losses net of recoveries.

- In January 2009, the government authorized the BoE to set up an APF to buy highquality assets financed by the issue of treasury bills and the DMO's cash-management operations to improve liquidity in credit markets. In November 2010, the BoE provided notice of its intention to withdraw the Commercial Paper Facility for companies; the continuation of the Corporate Bond Secondary Market Scheme, which was introduced in March 2009 to both buy and sell corporate bonds; to make purchases through its Secured Commercial Paper Facility, which was announced in July 2009 to allow the BoE to purchase high-quality sterling commercial paper securities that support the financing of working capital. 


\section{APPENDIX III: ESTIMATION OF SATEllite MODElS IN THE U.K. FSAP UPDATE STRESS Testing EXercise AND Their APPlication}
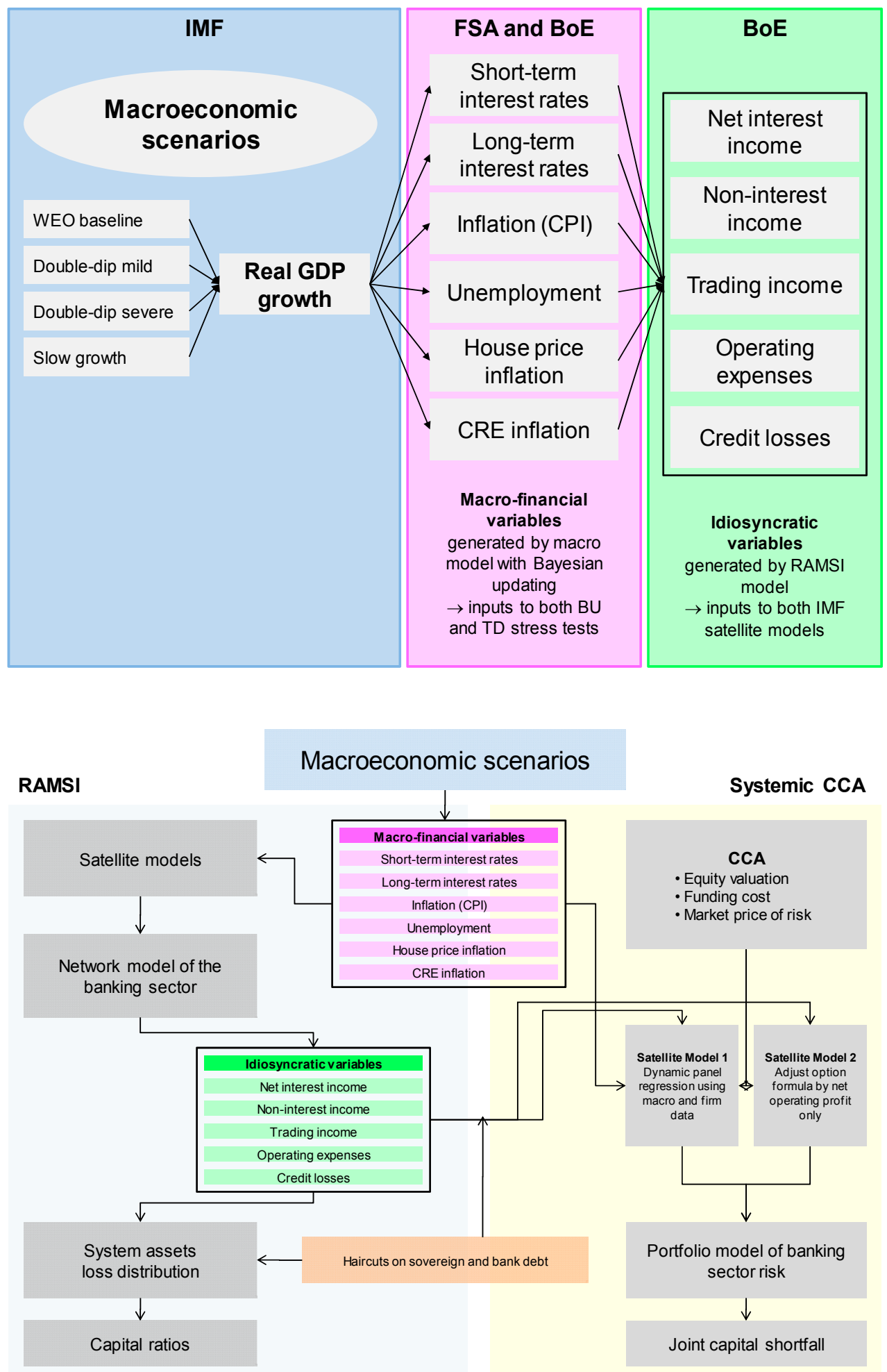
APPENDIX IV: KEY ASSUMPTIONS APPLIED IN THE U.K. FSAP UPDATE SOLVENCY STRESS TESTS

\begin{tabular}{|c|c|c|c|c|}
\hline \multirow[t]{2}{*}{ Domain } & \multirow[t]{2}{*}{ Element } & \multicolumn{3}{|c|}{ Assumptions } \\
\hline & & Bottom-Up by Banks & $\begin{array}{l}\text { Top-Down by Authorities } \\
\text { (BoE RAMSI) }\end{array}$ & $\begin{array}{c}\text { Top-down by FSAP Team } \\
\text { (Systemic CCA) }\end{array}$ \\
\hline Institutions & Banks & $\begin{array}{l}\text { - Seven SIFIs (Barclays, HSBC, } \\
\text { LBG, RBS, SCB, Santander } \\
\text { U.K., Nationwide). }\end{array}$ & $\begin{array}{l}\text { - Five SIFIs (Barclays, HSBC, } \\
\text { LBG, RBS, Santander U.K.). }\end{array}$ & $\begin{array}{l}\text { Seven SIFls (Barclays, HSBC, } \\
\text { LBG, RBS, SCB, Santander } \\
\text { U.K., Nationwide). }\end{array}$ \\
\hline Market share & $\begin{array}{l}\text { Assets } \\
\text { Lending }\end{array}$ & $\begin{array}{l}\text { - } 71 \text { percent of banking system } \\
\text { assets. } \\
\text { - } 89 \text { percent of total lending. }\end{array}$ & $\begin{array}{l}\text { - } 65 \text { percent of banking system } \\
\text { assets. } \\
\text { - } 79 \text { percent of total lending. }\end{array}$ & $\begin{array}{l}\text { - } 71 \text { percent of banking system } \\
\text { assets. } \\
\text { - } 89 \text { percent of total lending. }\end{array}$ \\
\hline Data & Source & - Banks' own data & $\begin{array}{l}\text { - Supervisory data } \\
\text { - Publicly available data }\end{array}$ & $\begin{array}{l}\text { - Supervisory data } \\
\text { - Publicly available data }\end{array}$ \\
\hline Methodology & Model & - Banks' internal models. & - BoE RAMSI. & - Systemic CCA. \\
\hline $\begin{array}{l}\text { Scope of } \\
\text { consolidation }\end{array}$ & & \multicolumn{3}{|l|}{ - Consolidated banking group. } \\
\hline Stress test horizon & Years & \multicolumn{3}{|l|}{ • 2011-2015. } \\
\hline Scenario & Macro-financial & \multicolumn{3}{|c|}{$\begin{array}{l}\text { - Shocks are conditional on macro scenarios (GDP, inflation, interest rates, unemployment, U.K. commercial } \\
\text { and residential property and equity prices). } \\
\text { GDP shock scenarios: } \\
\text { - One standard deviation from the WEO baseline. } \\
\text { - Two standard deviations from the WEO baseline. } \\
\text { - Prolonged slow growth (with greater than } 7 \text { percentage points in cumulative deviation from the WEO } \\
\text { baseline over five years). }\end{array}$} \\
\hline \multirow[t]{2}{*}{ Risk factors } & Credit losses & $\begin{array}{l}\text { - Credit losses are based on } \\
\text { banks' satellite models. }\end{array}$ & \multicolumn{2}{|c|}{$\begin{array}{l}\text { - Credit losses are based on satellite model using various macro and } \\
\text { bank-specific variables. }\end{array}$} \\
\hline & Profitability & $\begin{array}{l}\text { - Profit (interest income, interest } \\
\text { expense, net fee and } \\
\text { commission income, operation } \\
\text { expenses) should be based on } \\
\text { banks' satellite models or expert } \\
\text { judgment. } \\
\text { - Trading income is derived from } \\
\text { banks' satellite models or } \\
\text { statistical matching with GDP }\end{array}$ & \multicolumn{2}{|c|}{$\begin{array}{l}\text { - Profit and trading income are based on satellite models using various } \\
\text { macro and bank-specific variables. }\end{array}$} \\
\hline
\end{tabular}




\begin{tabular}{|c|c|c|c|c|}
\hline \multirow[t]{2}{*}{ Domain } & \multirow[t]{2}{*}{ Element } & \multicolumn{3}{|c|}{ Assumptions } \\
\hline & & Bottom-Up by Banks & $\begin{array}{l}\text { Top-Down by Authorities } \\
\text { (BoE RAMSI) }\end{array}$ & $\begin{array}{l}\text { Top-down by FSAP Team } \\
\text { (Systemic CCA) }\end{array}$ \\
\hline & & $\begin{array}{l}\text { growth (conditional on changes } \\
\text { in trading assets). }\end{array}$ & & \\
\hline & Funding costs & $\begin{array}{l}\text { - Funding costs are derived from } \\
\text { either satellite models for } \\
\text { interest expense or an IMF- } \\
\text { provided methodology. Changes } \\
\text { in costs due to solvency } \\
\text { conditions cannot be smaller } \\
\text { than those generated. }\end{array}$ & \multicolumn{2}{|c|}{$\begin{array}{l}\text { - Funding costs are based on satellite model using various macro and } \\
\text { bank-specific variables. }\end{array}$} \\
\hline & $\begin{array}{l}\text { Fixed income } \\
\text { holdings }\end{array}$ & $\begin{array}{l}\text { - Haircuts (using an IMF-provided } \\
\text { methodology) are applied to } \\
\text { holdings of both sovereign and } \\
\text { bank debt, in both the trading } \\
\text { and banking books. } \\
\text { - Haircuts are applied only to non- } \\
\text { AAA rated issuers. } \\
\text { - Cash at central banks as well as } \\
\text { repos or asset swaps where } \\
\text { there is no economic interest in } \\
\text { the security are excluded. }\end{array}$ & \multicolumn{2}{|c|}{$\begin{array}{l}\text { - Haircuts (using an IMF-provided methodology) are applied to holdings } \\
\text { of sovereign debt (based on latest available data-CEBS 2010) and to } \\
\text { bank debt (based on BIS consolidated banking statistics) in both the } \\
\text { trading and banking books. }\end{array}$} \\
\hline & Exchange rate & $\begin{array}{l}\text { - Impact of valuation changes of } \\
\text { net open positions as a result of } \\
\text { shocks to the U.S, dollar, the } \\
\text { euro and the Japanese yen. } \\
\text { - Shock should be twice the } \\
\text { standard deviation of the } \\
\text { respective FX volatility during } \\
2010 \text { and impact the trading } \\
\text { book in } 2011 \text { and } 2012 \text { only. }\end{array}$ & \multicolumn{2}{|l|}{ - N.A. } \\
\hline & Taxes & $\begin{array}{l}\text { - A rate of } 25 \text { percent in the case } \\
\text { of positive profits, zero } \\
\text { otherwise. }\end{array}$ & $\begin{array}{l}\text { - Each bank's tax/profit ratio set to } \\
\text { historical averages unless profits } \\
\text { are negative. Banks not } \\
\text { currently paying tax gradually }\end{array}$ & - N.A. \\
\hline
\end{tabular}




\begin{tabular}{|c|c|c|c|c|}
\hline \multirow{2}{*}{ Domain } & \multirow[t]{2}{*}{ Element } & \multicolumn{3}{|c|}{ Assumptions } \\
\hline & & Bottom-Up by Banks & $\begin{array}{l}\text { Top-Down by Authorities } \\
\text { (BoE RAMSI) }\end{array}$ & $\begin{array}{c}\text { Top-down by FSAP Team } \\
\text { (Systemic CCA) }\end{array}$ \\
\hline & & & increase their ratio from zero & \\
\hline Risk measurement & PDs and LGDs & $\begin{array}{l}\text { - Assumed to be "through the } \\
\text { cycle." }\end{array}$ & \multicolumn{2}{|l|}{ Point in time. } \\
\hline \multirow[t]{5}{*}{$\begin{array}{l}\text { Behavioral } \\
\text { adjustments }\end{array}$} & $\begin{array}{l}\text { Balance sheet } \\
\text { growth }\end{array}$ & $\begin{array}{l}\text { - Constant balance sheet } \\
\text { (growing in line with nominal } \\
\text { GDP). } \\
\text { Banks affected by stress reduce } \\
\text { asset growth through } \\
\text { deleveraging or other means. }\end{array}$ & $\begin{array}{l}\text { - Each bank holds assets flat } \\
\text { unless and until its capital ratio } \\
\text { target is met. }\end{array}$ & $\begin{array}{l}\text { - Endogenous to market } \\
\text { expectations implied by equity } \\
\text { cash and derivative prices. }\end{array}$ \\
\hline & Dividend payout & $\begin{array}{l}\text { - Payable out of the previous } \\
\text { year's profit and cannot result in } \\
\text { a drop below any of the } \\
\text { minimum capital requirements. } \\
\text { - Banks are assumed to pay out } \\
\text { dividends only if they report } \\
\text { profits, remain above minimum } \\
\text { capital requirement levels and } \\
\text { exhibit a leverage ratio of no } \\
\text { less than } 3 \text { percent in a given } \\
\text { year. } \\
\text { Payout rule consistent with } \\
\text { maximum payout ratios defined } \\
\text { under Basel III. }\end{array}$ & $\begin{array}{l}\text { - Constant dividend payout (at } \\
\text { current levels until capital ratio } \\
\text { target is met). }\end{array}$ & $\begin{array}{l}\text { Endogenous to market } \\
\text { expectations implied by equity } \\
\text { cash and derivative prices. }\end{array}$ \\
\hline & Asset disposal & $\begin{array}{l}\text { - Disallowed except where agreed } \\
\text { with legally binding } \\
\text { commitments under EC state aid } \\
\text { rules. } \\
\text { - Maturing exposures are } \\
\text { assumed to be replaced. }\end{array}$ & \multicolumn{2}{|l|}{ - No asset disposals. } \\
\hline & $\begin{array}{l}\text { Lending } \\
\text { standards and } \\
\text { credit balance }\end{array}$ & $\begin{array}{l}\text { - In accordance with changes in } \\
\text { credit growth experienced during } \\
\text { the last business cycle. }\end{array}$ & $\begin{array}{l}\text { - Determined by total asset } \\
\text { growth. }\end{array}$ & - N.A. \\
\hline & Portfolio & \multicolumn{3}{|l|}{ - No change. } \\
\hline
\end{tabular}




\begin{tabular}{|c|c|c|c|c|}
\hline \multirow[t]{2}{*}{ Domain } & \multirow[t]{2}{*}{ Element } & \multicolumn{3}{|c|}{ Assumptions } \\
\hline & & Bottom-Up by Banks & $\begin{array}{l}\text { Top-Down by Authorities } \\
\text { (BoE RAMSI) }\end{array}$ & $\begin{array}{c}\text { Top-down by FSAP Team } \\
\text { (Systemic CCA) }\end{array}$ \\
\hline & allocation & & & \\
\hline \multirow[t]{3}{*}{ Regulatory standards } & Hurdle rates & $\begin{array}{l}\text { - Solvency assessed in } \\
\text { accordance with the Basel III } \\
\text { schedule and the FSA Interim } \\
\text { Capital Regime. } \\
\text { - Basel III hurdle rates with capital } \\
\text { conservation buffers are tested } \\
\text { as a sensitivity check. }\end{array}$ & $\begin{array}{l}\text { - Solvency assessed in } \\
\text { accordance with the Basel III } \\
\text { schedule and the FSA Interim } \\
\text { Capital Regime. }\end{array}$ & $\begin{array}{l}\text { - Solvency assessed in } \\
\text { accordance with the Basel III } \\
\text { schedule and the FSA Interim } \\
\text { Capital Regime. }\end{array}$ \\
\hline & $\begin{array}{l}\text { Definition of } \\
\text { capital }\end{array}$ & $\begin{array}{l}\text { - Starting point is in line with FSA } \\
\text { definitions as laid out in the FSA } \\
\text { Handbook and the definition of } \\
\text { capital in the FSA Interim Capital } \\
\text { Regime. } \\
\text { - Phase-in of capital deductions. } \\
\text { - Phase-out of non-core Tier } 1 \\
\text { and Tier } 2 \text { capital elements. } \\
\text { - Existing capital instruments are } \\
\text { not grandfathered. }\end{array}$ & $\begin{array}{l}\text { - Basel II-consistent definition of } \\
\text { capital. }\end{array}$ & - Common equity (Tier 1 ). \\
\hline & RWAs & $\begin{array}{l}\text { - Changes in risk-weights for all } \\
\text { risk types increase at the same } \\
\text { rate as baseline nominal GDP } \\
\text { growth throughout period; } \\
\text { - Risk-weights for credit risk } \\
\text { reduced by the RWAs of } \\
\text { defaulted exposures. }\end{array}$ & $\begin{array}{l}\text { - No change in risk weights. } \\
\text { - Balance sheet growth as above. }\end{array}$ & $\begin{array}{l}\text { - RWAs are endogenous to } \\
\text { market valuation of bank risk. }\end{array}$ \\
\hline
\end{tabular}

Prepared by: BoE; and IMF staff. 


\section{Sovereign and Bank Debt Haircuts Applied in the U.K. FSAP Update Solvency Stress Tests, as at December 31, 2010 1/}

(In percent)

\begin{tabular}{|c|c|c|c|c|c|c|c|c|c|c|c|c|c|c|c|}
\hline \multirow[b]{3}{*}{ Forecast Year } & \multicolumn{15}{|c|}{5 -year rate } \\
\hline & \multicolumn{5}{|c|}{ Baseline } & \multicolumn{5}{|c|}{$\begin{array}{c}\text { Adverse } 1 \\
\text { (DD Mild and SG) } \\
\end{array}$} & \multicolumn{5}{|c|}{$\begin{array}{l}\text { Adverse } 2 \\
\text { (DD Severe) }\end{array}$} \\
\hline & 2011 & 2012 & 2013 & 2014 & 2015 & 2011 & 2012 & 2013 & 2014 & 2015 & 2011 & 2012 & 2013 & 2014 & 2015 \\
\hline Belgium & 1.76 & 1.88 & 1.79 & 1.66 & 1.55 & 4.56 & 4.74 & 4.61 & 4.42 & 4.26 & 9.49 & 9.84 & 9.55 & 9.12 & 8.71 \\
\hline France & 0.00 & 0.04 & 0.05 & 0.03 & 0.01 & 0.77 & 1.03 & 1.09 & 0.99 & 0.90 & 3.18 & 3.66 & 3.79 & 3.62 & 3.45 \\
\hline Germany & 0.00 & 0.00 & 0.02 & 0.00 & 0.00 & 0.30 & 0.41 & 0.45 & 0.43 & 0.43 & 1.37 & 1.66 & 1.84 & 1.82 & 1.79 \\
\hline Netherlands & 0.30 & 0.34 & 0.35 & 0.34 & 0.34 & 0.61 & 0.68 & 0.71 & 0.70 & 0.70 & 1.81 & 1.90 & 1.99 & 2.00 & 2.03 \\
\hline United Kingdom & 0.10 & 0.27 & 0.25 & 0.10 & 0.16 & 1.19 & 1.39 & 1.31 & 1.02 & 1.03 & 3.16 & 3.41 & 3.23 & 2.69 & 2.60 \\
\hline Greece & 12.77 & 10.85 & 9.07 & 8.21 & 7.28 & 26.61 & 23.20 & 20.00 & 18.56 & 16.81 & 46.55 & 41.57 & 36.74 & 34.61 & 31.82 \\
\hline Ireland & 6.12 & 5.55 & 4.77 & 4.26 & 3.78 & 13.83 & 12.81 & 11.39 & 10.56 & 9.59 & 26.35 & 24.71 & 22.35 & 21.05 & 19.34 \\
\hline Italy & 2.75 & 2.78 & 2.72 & 2.55 & 2.44 & 5.66 & 5.64 & 5.58 & 5.36 & 5.18 & 10.77 & 10.67 & 10.60 & 10.31 & 10.01 \\
\hline Portugal & 2.25 & 1.76 & 0.94 & 0.27 & 0.00 & 10.72 & 9.72 & 8.06 & 6.77 & 5.64 & 24.40 & 22.68 & 19.82 & 17.60 & 15.63 \\
\hline Spain & 1.90 & 1.73 & 1.56 & 1.37 & 1.25 & 6.10 & 5.74 & 5.44 & 5.17 & 5.02 & 13.35 & 12.66 & 12.16 & 11.76 & 11.56 \\
\hline United States & 0.14 & 0.17 & 0.20 & 0.21 & 0.23 & 0.36 & 0.49 & 0.65 & 0.75 & 0.85 & 1.34 & 1.74 & 2.14 & 2.39 & 2.60 \\
\hline \multicolumn{16}{|c|}{ Memo item: CEBS haircuts (absolute) } \\
\hline Belgium & 1.40 & 3.10 & - & - & - & 3.47 & 6.51 & - & - & - & & & & & \\
\hline France & 1.50 & 3.00 & - & - & - & 2.21 & 4.93 & - & - & - & & & & & \\
\hline Germany & 0.10 & 2.30 & - & - & - & 2.03 & 3.69 & - & - & - & & & & & \\
\hline Netherlands & 1.10 & 2.50 & - & - & - & 1.79 & 4.83 & - & - & - & & & & & \\
\hline United Kingdom & 5.00 & 6.90 & - & - & - & 2.56 & 5.52 & - & - & - & & & & & \\
\hline Greece & 3.90 & 4.30 & - & - & - & 22.60 & 30.22 & - & - & - & & & & & \\
\hline Ireland & 1.60 & 4.20 & - & - & - & 7.58 & 11.11 & - & - & - & & & & & \\
\hline Italy & 1.20 & 2.90 & - & - & - & 3.96 & 7.10 & - & - & - & & & & & \\
\hline Portugal & 2.30 & 3.70 & - & - & - & 10.94 & 15.92 & - & - & - & & & & & \\
\hline Spain & 1.30 & 4.10 & - & - & - & 6.55 & 9.86 & - & - & - & & & & & \\
\hline United States & 1.30 & 4.40 & - & - & - & 4.41 & 9.37 & - & - & - & & & & & \\
\hline \multicolumn{16}{|c|}{ Memo item: Difference between new haircuts and CEBS haircuts } \\
\hline Belgium & 0.36 & -1.22 & - & - & - & 1.09 & -1.77 & - & - & - & & & & & \\
\hline France & -1.50 & -2.96 & - & - & - & -1.44 & -3.91 & - & - & - & & & & & \\
\hline Germany & -0.10 & -2.30 & - & - & - & -1.73 & -3.29 & - & - & - & & & & & \\
\hline Netherlands & -0.80 & -2.16 & - & - & - & -1.18 & -4.15 & - & - & - & & & & & \\
\hline \multirow[t]{2}{*}{ United Kingdom } & -4.90 & -6.63 & - & - & - & -1.37 & -4.14 & - & - & - & & & & & \\
\hline & 0.00 & 0.00 & & & & 0.00 & 0.00 & & & & & & & & \\
\hline Greece & 8.87 & 6.55 & - & - & - & 4.01 & -7.03 & - & - & - & & & & & \\
\hline Ireland & 4.52 & 1.35 & - & - & - & 6.25 & 1.70 & - & - & - & & & & & \\
\hline Italy & 1.55 & -0.12 & - & - & - & 1.70 & -1.46 & - & - & - & & & & & \\
\hline Portugal & -0.05 & -1.94 & - & - & - & -0.22 & -6.20 & - & - & - & & & & & \\
\hline Spain & 0.60 & -2.37 & - & - & - & -0.45 & -4.13 & - & - & - & & & & & \\
\hline United States & -1.16 & -4.23 & - & - & - & -4.05 & -8.88 & - & - & - & & & & & \\
\hline
\end{tabular}

Source: Bloomberg; and IMF staff calculations.

$1 /$ The estimated haircuts have been applied to debt holdings of all non-AAA rated sovereigns as well as all exposures (debt and loans) to banks in these countries on an ultimate-risk basis. The severity and dynamics of these haircuts are informed by the forward term structure of five-year sovereign CDS spreads as at end-2010. These sovereign CDS spreads are expected to increase commensurately with the rising risks to the economic outlook, with both changes determined by consistent decline of statistical probability. Changes to the outlook for sovereign risk since end-2010 are not reflected in these haircuts, given the cut-off point for the stress tests. 


\section{APPENDIX V: PARAMETERS APPLIED IN THE U.K. FSAP UPDATE LiQUidity STRESS TeSTS}

\begin{tabular}{|c|c|c|c|c|}
\hline \multirow[t]{2}{*}{ Test } & \multirow[t]{2}{*}{ Definition } & \multicolumn{2}{|c|}{ Basic Assumptions } & \multirow[t]{2}{*}{ Other Assumptions } \\
\hline & & Asset Side (Cash inflows) & Liabilities (Cash outflows) & \\
\hline & \multicolumn{4}{|c|}{ Implied Cash Flow Test } \\
\hline 5-daytest & $\begin{array}{l}\text { Consecutive outflow } \\
\text { of liabilities over five } \\
\text { days. }\end{array}$ & $\begin{array}{l}\text { Asset that remain liquid under stress and haircuts (one-off): } \\
\text { (i) cash and cash-equivalent positions (haircut: } 0 \text { percent); } \\
\text { (ii) government debt holdings; (0), (iii) investments (securities) } \\
\text { (20); (iv) trading securities (20); (v) derivatives (50); (vi) high- } \\
\text { quality investment securities (1); and (vii) secured assets (up to } \\
\text { one month) (1). }\end{array}$ & $\begin{array}{l}\text { (i) demand deposits ( } 5 \text { percent per day, except from sovereigns } \\
\text { (0 percent per day)); (ii) term deposits ( } 1 \text { percent); and } \\
\text { (iii) secured/unsecured wholesale funding ( } 5 / 15 \text { percent). }\end{array}$ & $\begin{array}{l}10 \text { percent of the liquid assets are } \\
\text { encumbered, i.e., used as a collateral to } \\
\text { receive funding (with the exception of } \\
\text { cash/cash-equivalents); no offsetting cash } \\
\text { inflows from wholesale lending (at contractual } \\
\text { maturities); no inflows of interbank lending in } \\
\text { times of stress; no consideration of access to }\end{array}$ \\
\hline 30-day test & $\begin{array}{l}\text { One-off aggregate } \\
\text { outflow of liabilities } \\
\text { for } 30 \text { days. }\end{array}$ & $\begin{array}{l}\text { Asset that remain liquid under stress and haircuts (one-off): } \\
\text { (i) cash and cash-equivalent positions (0); (ii) government debt } \\
\text { holdings (1); (iii) investments (securities) (10); (iv) trading } \\
\text { securities (40); (v) derivatives (50); (vi) high-quality investment } \\
\text { securities (5); and (vii) secured assets (up to one month) (75). }\end{array}$ & $\begin{array}{l}\text { (i) demand deposits by non-financial/financial entities (50/75); } \\
\text { (ii) term deposits by non-financial/financial entities (20/30); } \\
\text { (iii) secured/unsecured wholesale funding (40/50); and } \\
\text { (iv) intragroup funding (20). }\end{array}$ & the Bank of England discount window. \\
\hline \multirow[t]{2}{*}{ Memo item } & \multicolumn{4}{|c|}{$\begin{array}{l}\text { The FSA does not complete tests that are directly comparable to these results due to a process of individualized liquidity risk monitoring. However, the survival day metric monitored by the FSA to assess } \\
\text { vulnerabilities to wholesale funding is broadly similar to the } 30 \text {-day test. The FSA collects daily cash flow data for three months from the reporting date in respect of wholesale secured and unsecured cash flows to } \\
\text { assess if a firm can withstand lock-out in wholesale funding markets by using a stock of high-quality marketable assets. High-quality assets constitute the following type of assets: liquid assets as set out in FSA } \\
\text { BIPRU } 12.7 \text {, other central bank and government securities rates above "credit step 1" and securities issued by U.S. GSE/GSAs. Wholesale cumulative funding gap is calculated by using the daily inflows and } \\
\text { outflows. The stock of high quality buffer assets, which a firm holds or will receive in repo operations, is added th this cumulative gap to calculate cash flow gap after accounting for high-quality collateral. Survival } \\
\text { days are defined as the first day on which the cumulative wholesale refinancing gap after adding the high quality assets turns negative. For this exercise, the FSA finds that } 75 \text { percent of all firms in the full sample }\end{array}$} \\
\hline & \multicolumn{4}{|c|}{ Proposed Basel III Measures } \\
\hline $\begin{array}{l}\text { Quasi-Liquidity } \\
\text { Coverage Ratio (LCR) }\end{array}$ & $\begin{array}{l}\text { Stock of high-quality } \\
\text { liquid assets would } \\
\text { need to cover short- } \\
\text { term net cash } \\
\text { outflows. }\end{array}$ & $\begin{array}{l}\text { Assets that remain liquid under stress: (i) high-quality bonds } \\
\text { and covered bonds (rated "AA-" and higher) (15); sovereign, } \\
\text { central bank and PSE assets qualifying for } 20 \text { percent risk- } \\
\text { weighting (15). }\end{array}$ & $\begin{array}{l}\text { (i) term deposits with residual maturity > } 1 \text { month (0); } \\
\text { (ii) stable/less stable retail deposits }(5 / 10) \text {; (iii) unsecured } \\
\text { wholesale funding with/without operational relationship/funding } \\
\text { from other entities (financial institutions) ( } 25 / 75 / 100) ; \\
\text { (iv) percentage of interbank market funding secured with illiquid } \\
\text { assets (100); (v) secured funding backed by "Level 1" } \\
\text { assets/"Level 2" assets and by other valuable assets (close to } \\
\text { "Level 2") (0/15/25); (vi) portion of high-quality liquid asset } \\
\text { needed to satisfy margin calls (10); and (vii) market value } \\
\text { change on derivatives (20). }\end{array}$ & $\begin{array}{l}\text { (i) asset-backed assets maturing within } 30 \\
\text { days (10); (ii) portion of undrawn but } \\
\text { committed funding liabilities that are drawn } \\
\text { (50); (iii) portion of assets reinvested (20); and } \\
\text { (iv) renewal rate for amortizing loans and other } \\
\text { assets ( } 100) \text {; no inflows of interbank lending } \\
\text { in times of stress, and no consideration of } \\
\text { access to the Bank of England discount } \\
\text { window. }\end{array}$ \\
\hline $\begin{array}{l}\text { Quasi-Net Stable } \\
\text { Funding Ratio (NSFR) }\end{array}$ & $\begin{array}{l}\text { Available stable } \\
\text { sources of funding } \\
\text { need to exceed the } \\
\text { required level of } \\
\text { required funding. }\end{array}$ & 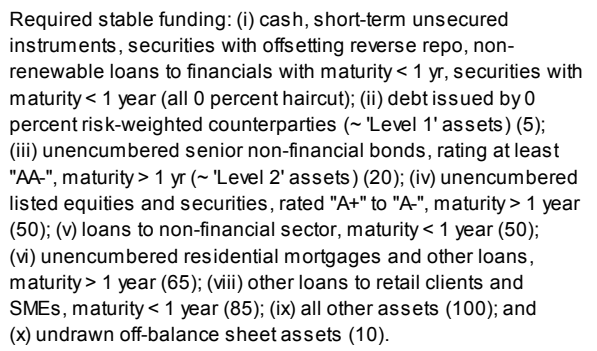 & $\begin{array}{l}\text { Available stable funding: (i) capital and long-term debt ( }>1 \text { year) } \\
\text { (100); (ii) stable deposits of retail and SMEs }(<1 \text { year) }(90) \text {; } \\
\text { (iii) less stable deposits of retail and SMEs }(<1 \text { year) }(80) ; \\
\text { (iv) wholesale funding provided by non-financials }(<1 \text { year) (50); } \\
\text { and (v) all other liabilities }(0) \text {. }\end{array}$ & $\begin{array}{l}\text { No inflows of interbank lending in times of } \\
\text { stress, and no consideration of access to the } \\
\text { Bank of England discount window. }\end{array}$ \\
\hline
\end{tabular}

Sources: FSA; and IMF staff. 


\section{Appendix VI: Hedge Funds, Prime Brokerage, and Collateral REHYPOTHECATION IN THE UNITED KINGDOM}

70. Approximately 20 percent of all hedge fund managers are registered in London with assets under management of approximately $\$ 380$ billion as at end-2010. ${ }^{17}$ Europe's share of fund managers grew from 12 percent in 2002 to 23 percent in 2009, eroding the U.S. position from 82 percent to 68 percent, with most of that business moving to London. ${ }^{18}$ An estimated 85 percent of the assets of these funds are domiciled in offshore locations.

\section{U.K. fund managers employ a range of strategies with the largest share} (35 percent) in long/short equities. The FSA has analyzed the market dominance of U.K. hedge fund managers and has concluded that, except in the case of convertible bonds, U.K. hedge fund managers do not control a significant portion of any given asset market. For example, funds managed from the United Kingdom hold only about 1 percent of the European equity market; U.K.-managed funds held 8 percent of the world's convertible bond market as at April 2010.

\section{The FSA measurement of fund leverage, which does not account for short/long} position netting, indicates that U.K.-managed funds employed an average of 272 percent of assets to equity in April 2010, up from 244 percent in October 2009.

There has been an increase in borrowing under repo agreements and a decline in borrowing through collateralized prime brokerage, reflecting lessons learned from the Lehman collapse, where hedge funds took losses as unsecured creditors under collateralized borrowing arrangements. ${ }^{19}$

73. Prime brokerage services are an important feature in the U.K. financial system, with 90 percent of European prime brokerage activity taking place in London. There is also a heavy concentration of administration and other services used by hedge funds. Prime

\footnotetext{
${ }^{17}$ Hedge fund managers in the United Kingdom are subject to registration and reporting requirements and are supervised by the FSA. Funds themselves are not regulated. The new EU Alternative Investment Fund Managers (AIFM) Directive will become the new framework for hedge-fund regulation. The Directive was agreed by the European Parliament in November 2010 and is expected to come into force June 2011. Level II rules will be developed by the European Securities and Markets Authority (ESMA). There is no consensus yet on key issues that impact the location of managers - including whether fund managers regulated in one jurisdiction can sell funds into the rest of the EU. Hedge fund data are generally not easy to interpret owing to the lack of a consistent definition of what constitutes a hedge fund and the fact that the industry is unregulated and not subject to detailed reporting in many jurisdictions. Our estimates rely on data from AIMA, FSA and IFSL Research.

${ }^{18}$ ISFL Research, 2010, "Hedge Funds 2010” (London, April).

${ }^{19}$ Financial Services Authority, 2010, “Assessing Possible Sources of Systemic Risk from Hedge Funds: A Report on the Findings of the Hedge Fund Survey and Hedge Fund as Counterparty Survey," (London, July).
} 
brokerage activity is subject to oversight and prudential controls - large global banks and investment banks are regulated by the FSA. Goldman Sachs, JP Morgan, and Morgan Stanley are the three largest players, with 52 percent of the global business. The FSA hedge fund survey suggests that the maximum potential credit exposure to any one hedge fund was $\$ 500$ million, with a maximum potential credit exposure of a single financial institution to a single hedge fund of $\$ 50$ million. ${ }^{20}$ The survey shows a trend of increased margin requirements for collateralized borrowing by hedge funds.

74. The presence of the hedge fund industry in the United Kingdom does not in itself represent a vulnerability for the U.K. financial system. However, the interconnectedness of funds and their importance to asset markets are key issues in financial stability surveillance. Although the FSA tracks U.K.-managed funds, it does not have information on the remaining 80 percent of the global industry, which actively trades or seeks prime brokerage services in the United Kingdom. This lack of data is a matter of global concern as the U.K. authorities, along with others, address data gaps for macroprudential surveillance.

75. The re-use of customer (mainly hedge fund) collateral acquired in repurchase transactions or as security under prime brokerage agreements (sometimes called rehypothecation) is widespread in the London financial markets. ${ }^{21}$ Under repurchase agreements, title to the collateral is formally transferred from the customer to the lender, while most prime brokerage agreements involve loans secured by a fixed charge under U.K. law over assets held in a nominee company. In the event of default under either form of arrangement, the collateral is sold to reimburse the lender.

\section{In rehypothecation, instruments taken as collateral are on-lent to other} customers or used as collateral for financing by the prime broker (investment bank). The repurchase counterparty or prime-broker profits from the re-use of the collateral in the form of stock lending fees or is able itself to borrow at lower rates than would otherwise have been the case. Rehypothecation is common across all asset classes, both equity and fixed income. It is carried out in the trading book (not the banking book) of the entities concerned.

\footnotetext{
${ }^{20}$ See FSA, 2011, “Assessing the Possible Sources of Systemic Risk from Hedge Funds," A Report on the Findings of the Hedge Fund Survey and Hedge Fund as Counterparty Survey (London, February). The U.K. regulatory system does not distinguish between commercial banks and investment banks, these figures include both.

${ }^{21}$ Retail customer assets are not included.
} 
77. The rehypothecation legal framework in the United Kingdom is different than that in the United States and has greater appeal for certain kinds of assets. ${ }^{22}$ The U.S. framework is very efficient for purely U.S. portfolios. The U.K. framework is based on U.K. commercial and trust law and is better adapted to assets in a global portfolio; it involves much more specificity in contracts to cover the various underlying bankruptcy, security, tax, and accounting regimes.

78. The central risk in rehypothecation is counterparty risk. The original provider of the collateral (hedge fund or other institutional investors) is exposed to the prime broker and to the risk the prime broker takes in reusing the collateral. Rehypothecation therefore increases the interconnectedness of firms and the difficulty in unwinding transactions. The collapse of Lehman Brothers exposed several poor practices - some contracts did not have netting provisions and some client assets held in custody proved to have been commingled with prime brokerage assets (in large part because funds had agreed to this commingling in return for less-expensive funding). A provision of bankruptcy law specifying that estate administrators may have personal liability for distribution decisions has also proven to be problematic. As a result, some hedge funds did not have assets returned and remain claimants against the Lehman estate. Contracts with prime brokers (investment banks) have since been tightened to include netting provisions and the use of client assets is generally proscribed or specifically limited. The FSA has also implemented stronger client asset rules and has undertaken targeted on-site evaluations of firm's systems and controls in this area.

79. Rehypothecation facilitates the movement of liquidity through the system, but does not add to it. Under IFRS accounting conventions, all lending transactions involving rehypothecation are shown in gross terms on the balance sheet. This results in a higher measured level of leverage than for comparable U.S. transactions, where netting is permitted for certain types of exposure.

\footnotetext{
${ }^{22}$ It is difficult to compare the two systems: they are influenced both by regulation and by the bankruptcy, tax and accounting regimes in place in either jurisdiction. The U.S. regulatory framework generally imposes greater limits both in terms of how much collateral can be taken and how it can be reinvested, though with significant exceptions. The United Kingdom does not impose such limits through regulation, but they are instead set out contractually in each transaction.
} 